\title{
ipen
}

AUTARQUIA ASSOCIADA À UNIVERSIDADE DE SÃO PAULO

UTILIZAÇÃO DA RADIAÇÃO IONIZANTE NA RECICLAGEM DE PNEUS INSERVÍVEIS DE AUTOMÓVEL E SUA DESTINAÇÃO AMBIENTAL ADEQUADA

Clécia de Moura Souza

Dissertação apresentada como parte dos requisitos para obtenção do Grau de Mestre em Ciências na Área de Tecnologia Nuclear - Aplicações

Orientador:

Prof. Dr. Leonardo Gondim de Andrade e Silva 


\title{
INSTITUTO DE PESQUISAS ENERGÉTICAS E NUCLEARES
}

Autarquia associada à Universidade de São Paulo

\section{UTILIZAÇÃO DA RADIAÇÃO IONIZANTE NA RECICLAGEM DE PNEUS INSERVÍVEIS DE AUTOMÓVEL E SUA DESTINAÇÃO AMBIENTAL ADEQUADA}

\author{
Clécia de Moura Souza
}

Dissertação apresentada como parte dos requisitos para obtenção do Grau de Mestre em Ciências na Área de Tecnologia Nuclear - Aplicações

Orientador:

Prof. Dr. Leonardo Gondim de Andrade e Silva

Versão Corrigida

Versão Original disponível no IPEN 
À minha mãe Marinete de Moura Souza e ao meu pai Geraldino José de Souza por toda a educação que me deram e as minhas irmãs por me ensinarem a ter paciência e ao meu marido Marcos Ferreira dos Santos pela compreensão. 


\section{AGRADECIMENTOS}

À Deus pela dádiva da vida e por ter me permitido conviver com todos os tipos de pessoas me oferecendo a oportunidade de aprender e me tornar uma pessoa melhor a cada dia;

Ao meu orientador Prof. Dr. Leonardo Gondim de Andrade e Silva pela orientação, confiança e o tempo a mim dedicado;

À Comissão Nacional de Energia Nuclear (CNEN) pela bolsa concedida;

A Dra. Yasko Kodama por todo o auxílio na realização deste trabalho pela amizade e paciência a mim dedicadas;

Ao Prof. Dr. Jivaldo do Rosário Matos e ao Laboratório de Análise Térmica Professor Doutor Ivo Giolotto (LATIG) do Instituto de Química da USP (IQUSP), pela disponibilidade de seus laboratórios e aos alunos do laboratório LATIG em especial a Juliana e a Natália pelo auxílio para realizar as curvas de Termogravimetria (TG) e Calorimetria Exploratória Diferencial (DSC);

Ao técnico Celso Vieira Morais, MSc. Gláuson Aparecido Ferreira Machado e a Dra. Flávia Rodrigues de Oliveira Silva, do Centro de Caracterização de Materiais, CCTM, do IPEN, pelo curso no equipamento Tabletop e pelas micrografias de MEV;

Ao Antônio José Santana pelo auxílio na determinação da granulometria do pó de borracha de pneus inservíveis de automóvel, do Laboratório de Matéria prima Particulados e Sólidos Não Metálicos - LMPSol, do Departamento de Engenharia de Materiais, Escola Politécnica da USP (EPUSP);

Ao Dr. Nilson Casemiro Pereira e ao técnico Luís Henrique Silveira, da Universidade Mackenzie pela autorização para a utilização do Laboratório de Caracterização e Processamento de Materiais - UPM da Escola de Engenharia de Materiais e pela disponibilidade do tempo para a realização das misturas das amostras;

Ao Prof. Dr. Fábio José Esper pela disponibilidade de seus laboratórios na Indústria de Artefatos de Borracha Esper Ltda. e pela doação de materiais e ao técnico Alésio pelo auxílio na preparação das amostras;

Ao Prof. Dr. Hélio Wiebeck por ter participado no exame de capacitação e tornado possível este trabalho;

Ao Instituto de Pesquisas Energéticas e Nucleares (IPEN/CNEN - SP), por toda a sua estrutura para a pesquisa o que tornou possível o desenvolvimento deste trabalho; 
Ao Centro de Tecnologia das Radiações, CTR do IPEN, ao Dr. Wilson Aparecido Parejo Calvo, Gerente do CTR e a Dra. Margarida Mizue Hamada, gerente Adjunta de P\&D.

Aos engenheiros Carlos Gaia da Silveira e Elisabeth S.R. Somessari pelas irradiações;

Ao Dr. Nelson Minoru Omi, pela contribuição na área de informática;

Ao MSc. Djalma Batista Dias, pela colaboração na realização dos ensaios mecânicos;

A Dra. Luci Diva Brocardo Machado, pela disponibilidade do laboratório de análise térmica;

Ao MSc. Hiroshi pelo auxílio na realização dos espectros de infravermelho com transformada de Fourier;

Aos secretários do Centro de Tecnologia das Radiações Cláudia Regina Nolla e Marcos Cardoso da Silva por toda a paciência e apoio na secretaria;

Aos colegas e amigos que fiz no IPEN e na Universidade de São Paulo (USP) pela amizade e pelas horas de descontração, Dra. Márcia, MSc. Carla Souza, MSc. Beatriz Ribeiro Nogueira, MSc. Amanda Koike, MSc. Henrique Perez Ferreira, MSc. Gabriela Hizume, MSc. Giovana Gimiliani, Stefany Plumeri, Rodrigo Mosca, Luiza Stecher, Mara de Mello Munhoz e Marcelo Bardi;

A todos que direta ou indiretamente contribuíram na realização deste trabalho muito obrigado. 
"Tenho pensamentos que, se pudesse revelá-los e fazê-los viver, acrescentaria nova luminosidade às estrelas, nova beleza ao mundo e maior amor ao coração dos homens".

Fernando Pessoa 


\title{
UTILIZAÇÃO DA RADIAÇÃO IONIZANTE NA RECICLAGEM DE PNEUS INSERVÍVEIS DE AUTOMÓVEL E SUA DESTINAÇÃO AMBIENTAL ADEQUADA
}

\author{
CLÉCIA DE MOURA SOUZA
}

\section{RESUMO}

O objetivo deste trabalho foi utilizar a radiação ionizante na reciclagem de pneus inservíveis de automóvel. As amostras de borracha de pneus inservíveis foram irradiadas com doses de radiação de 200, 400 e 600kGy, em um acelerador de elétrons. Posteriormente, elas foram caracterizadas por termogravimetria (TG), calorimetria exploratória diferencial (DSC), ensaios mecânicos de tração, espectrofotometria de infravermelho por transformada de Fourier (FTIR) e microscopia eletrônica de varredura (MEV). Por TG foi possível observar os efeitos da radiação na perda de massa do material. Por DSC observou-se as curvas exotérmicas associadas à decomposição e valores de variação de entalpia $(\Delta \mathrm{H})$. Foram estudadas as propriedades mecânicas das amostras da matriz elastomérica com o pó de pneu inservível e verificado o seu comportamento frente à radiação ionizante. Os espectros FTIR foram obtidos na região de $4000-650 \mathrm{~cm}^{-1}$. Observou-se que não foi possível observar alteração nos picos devido à irradiação. Nos ensaios por MEV as micrografias foram ampliadas de 32 vezes até 1000 vezes e observadas nos tamanhos de $1 \mathrm{~mm}$ até $20 \mu \mathrm{m}$. Observou-se nas doses de 200 e 400kGy, rugosidades correspondentes a quebras ou rupturas, possivelmente causadas pela radiação. Na dose de 600kGy, foi possível observar cavidades causadas pela radiação. Observou-se que para todas as doses houve degradação. Para as amostras dos corpos de prova sem pó e com pó de pneus inservíveis com 10\%, 30\% e 50\% de pó as micrografias foram observadas nas ampliações de $100 \mu \mathrm{m}$ e $200 \mu \mathrm{m}$. Também foi possível observar a 
incorporação do pó de pneus inservíveis de automóvel na matriz elastomérica das amostras não irradiadas e irradiadas. 


\title{
USE OF IONIZING RADIATION IN THE RECYCLING OF UNSERVICEABLE TIRES OF AUTOMOTIVE AND ITS ADEQUATE ENVIRONMENTAL DISPOSAL
}

\author{
CLÉCIA DE MOURA SOUZA
}

\begin{abstract}
The aim of this study was to use ionizing radiation in the recycling of scrap tires of automotive. Samples of rubber unserviceable tires were irradiated with radiation doses 200, 400 and 600kGy in an electron accelerator. Subsequently, they were characterized by thermogravimetry (TG), differential scanning calorimetry (DSC), tensile strenght mechanical test, spectrophotometry Fourier transform infrared (FTIR) and scanning electron microscopy (SEM). By thermogravimetry was possible to observe the effects of radiation in the mass loss of material. In the DSC curves were observed exothermic decomposition peaks and associated values of enthalpy variation $(\Delta H)$. The mechanical properties of the elastomeric matrix with unserviceable tires powder were studied and its behavior to ionizing radiation was analyzed. FTIR spectra were obtained in the $4000-650 \mathrm{~cm}^{-1}$ region. It was observed that there was no change in the peaks due irradiation. For SEM the micrographs were enlarged from 32 times up to 1000 times and observed in sizes from $1 \mathrm{~mm}$ up to $20 \mu \mathrm{m}$. It was observed at doses of 200 and $400 \mathrm{kGy}$, roughness corresponding to breaks or ruptures possibly caused by radiation. In 600kGy radiation dose was observed cavities caused by radiation. It was observed that at all doses occurred degradation. For samples without powder and with 10, 30 and 50\% of unserviceable tires powder it was obtained micrographs of $100 \mu \mathrm{m}$ and $200 \mu \mathrm{m}$ amplification. Also it was possible to observe the incorporation of unserviceable tires powder of automotive in the elastomeric matrix of non-irradiated and irradiated samples.
\end{abstract}




\section{SUMÁRIO}

Página

1 INTRODUÇÃ

1.1 Resolução do Conselho Nacional do Meio Ambiente (CONAMA) de 2009 ....................23

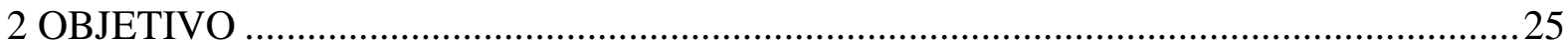

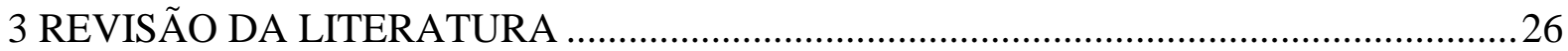

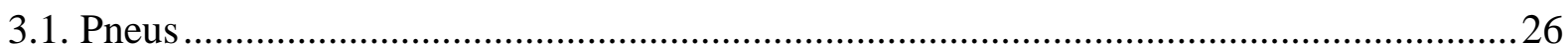

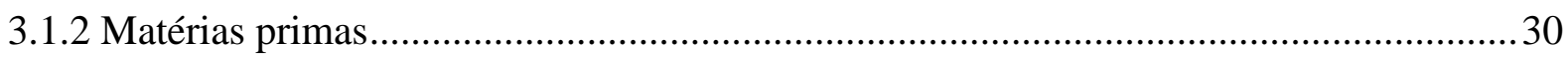

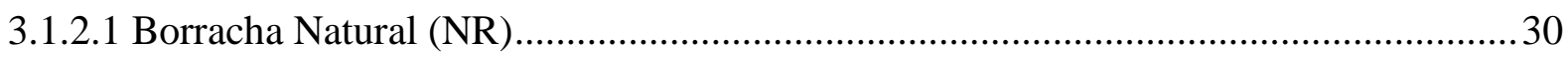

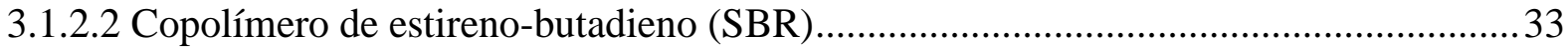

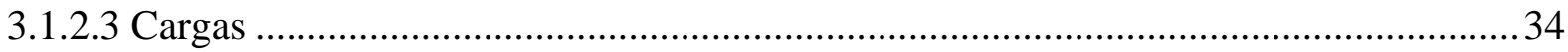

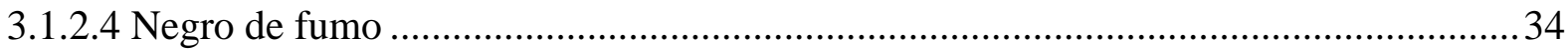

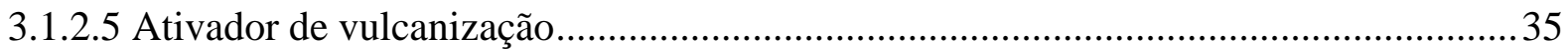

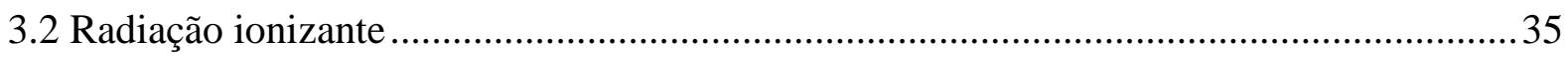

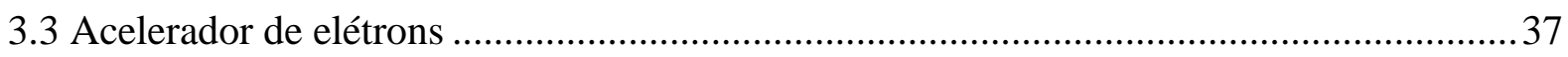

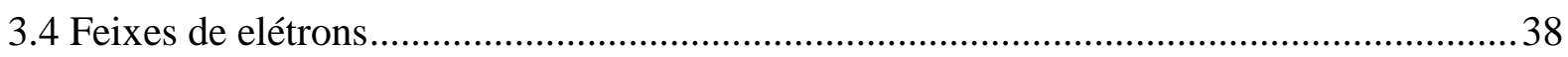

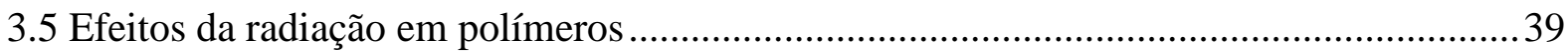

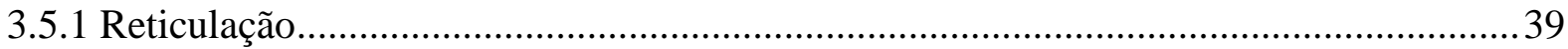

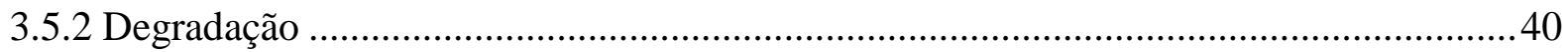

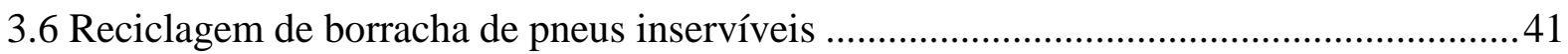

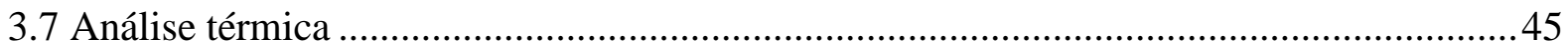

3.7.1 Termogravimetria (TG) e Termogravimetria Derivada (DTG) ...................................46

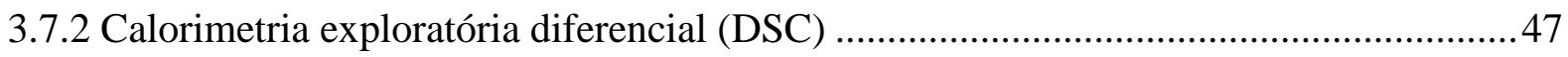

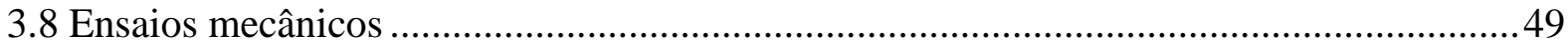

3.8.1 Resistência à tração, flexão e compressão ...................................................................49

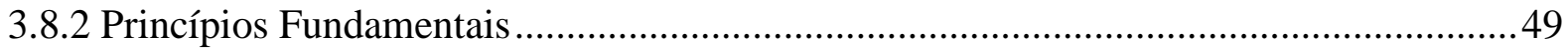

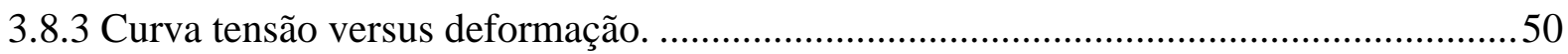

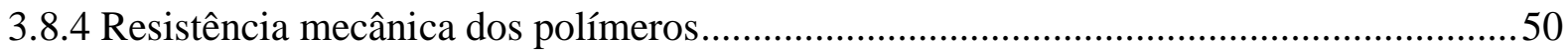

3.8.5 Comportamento dos polímeros em ensaios mecânicos ..................................................51

3.8.6 Comportamento deformacional de polímeros...........................................................53

3.8.7 Testes padronizados para os ensaios mecânicos sob tração, flexão e compressão..........53 
3.8.8 Acessórios da Máquina Universal de Ensaios ............................................................54

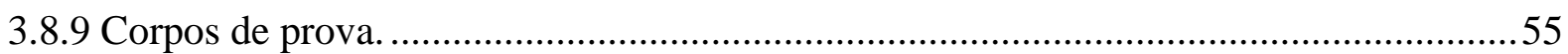

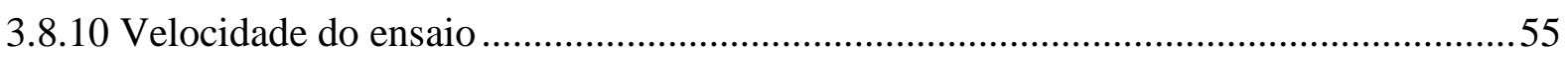

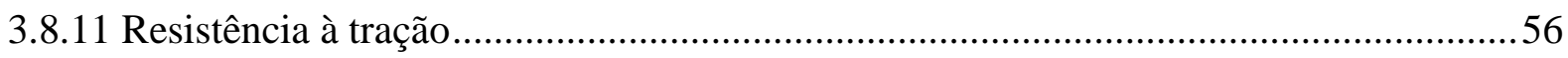

3.8.11.1 Tensão no limite do escoamento no ensaio de resistência à tração ...........................56

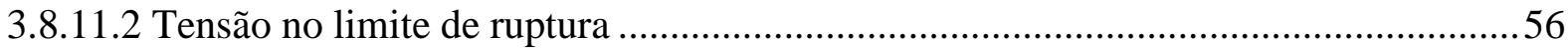

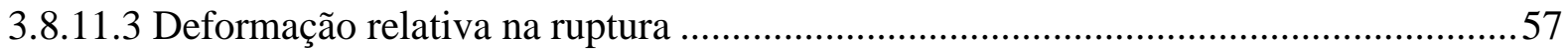

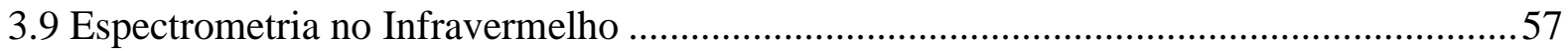

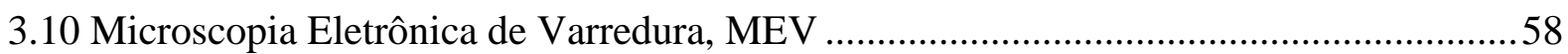

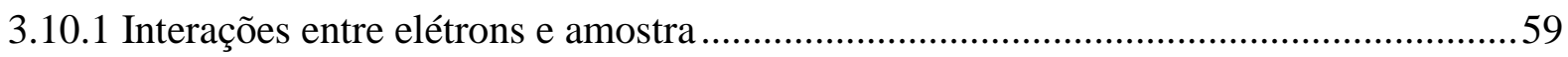

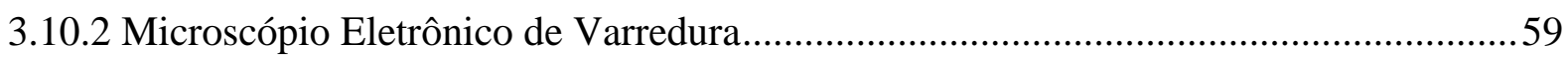

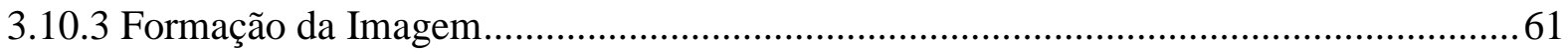

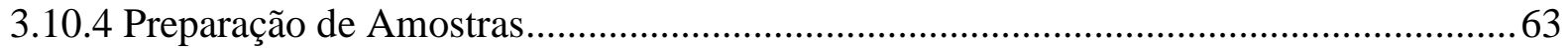

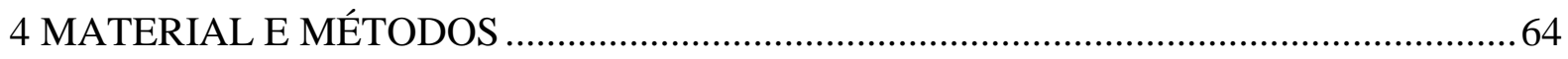

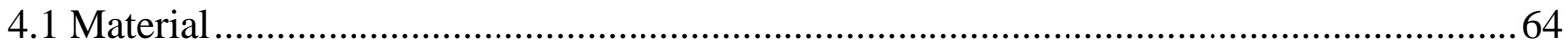

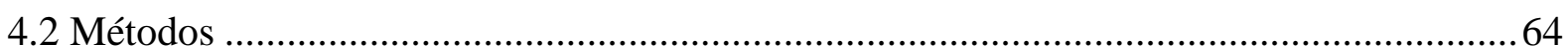

4.2.1 Preparação das amostras em grânulos para irradiação....................................................65

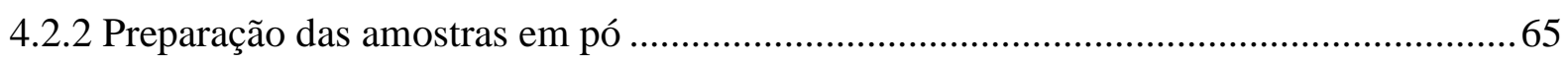

4.2.3 Incorporação dos aditivos na matriz de borracha natural .............................................66

4.2.4 Incorporação do pó de borracha de pneus na matriz de borracha natural......................67

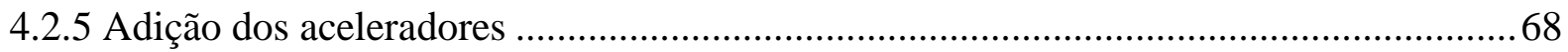

4.2.6 Vulcanização e confecção dos corpos de prova.............................................................69

4.2.7 Caracterização das amostras em grânulos e dos corpos de prova de borracha de pneus

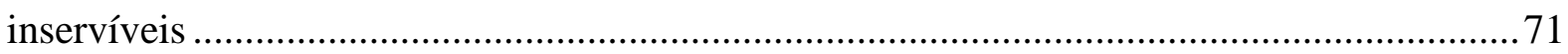

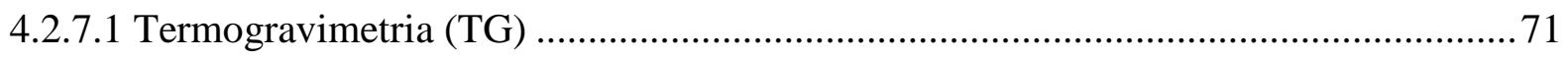

4.2.7.2 Calorimetria exploratória diferencial (DSC) …...................................................... 71

4.2.7.3 Espectroscopia de absorção na região do infravermelho com transformada de

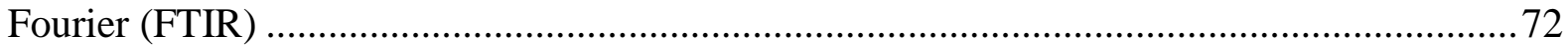

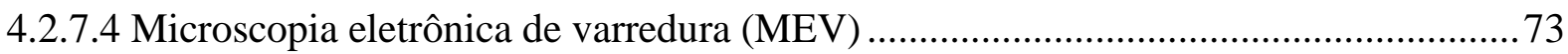

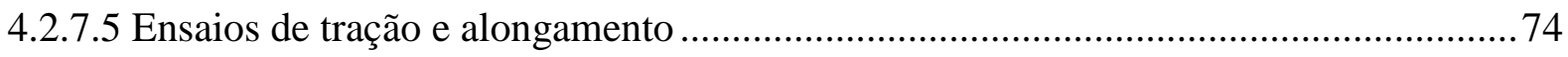

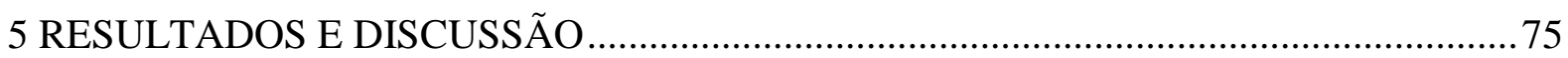

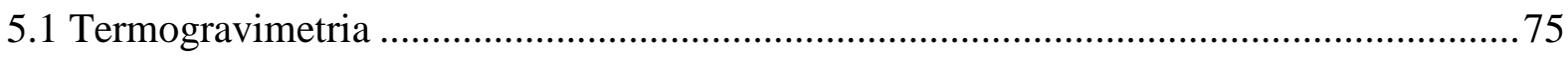

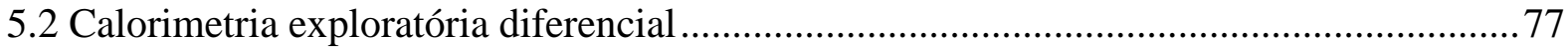

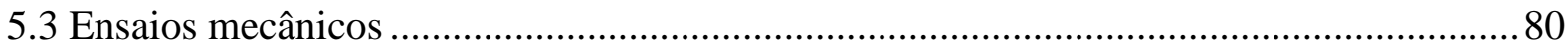


5.4 FTIR

.85

5.5 Microscopia Eletrônica de Varredura..... .87

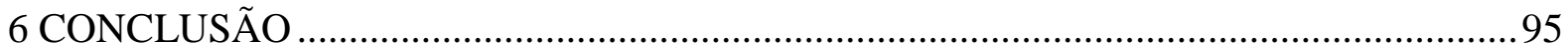

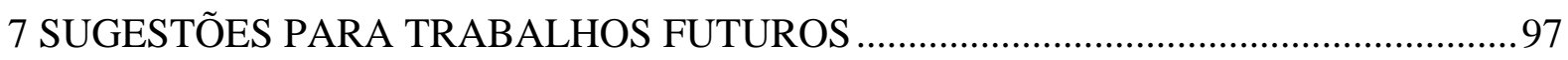

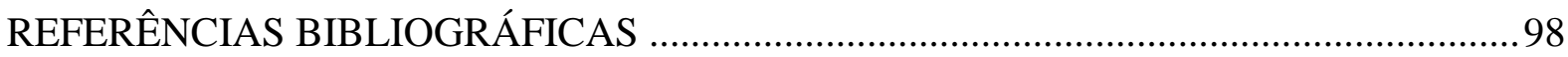




\section{LISTA DE FIGURAS}

FIGURA 1- Constituição de um pneu 27

FIGURA 2 - Extração do látex. (a) cortes superficiais na seringueira, (b) látex sendo coletado

FIGURA 3 - Mero da cadeia polimérica da borracha natural: unidade repetitiva do poli(1,4 cis isopreno)

FIGURA 4 - Fórmula estrutural da borracha SBR (MISAWA, 2001; HIBBS, 1990)

FIGURA 5 - Comparação de um tubo de imagens de um televisor com o acelerador de elétrons

FIGURA 6 - Curvas tensão versus deformação obtidas no ensaio de tração de diferentes tipos de polímeros. O comportamento frágil (A), comportamento dúctil (B) e comportamento elástico $(\mathrm{C})$

FIGURA 7- Efeito da temperatura no comportamento mecânico de um elastômero. 52

FIGURA 8 - Geometria e dimensões típicas de corpos de prova para ensaios de tração em polímeros 55

FIGURA 9 - Diagrama esquemático mostrando os principais componentes de um microscópio eletrônico de varredura.

FIGURA 10 - Volume de integração e regiões onde são detectados elétrons secundários, retroespalhados e raios $\mathrm{X}$ 62

FIGURA 11 - Acelerador de elétrons Dynamitron II modelo DC 1500 JOB 188 65 FIGURA 12 - Conjunto de peneiras nos tamanhos $710 \mu \mathrm{m}, 355 \mu \mathrm{m}, 250 \mu \mathrm{m}$ e $125 \mu \mathrm{m}$ e agitador de peneiras granulométrico eletromagnético 66

FIGURA 13 - Misturador aberto tipo (calandra)

FIGURA 14 - Processo de mistura de óxido de zinco e de ácido esteárico. a) borracha natural. b) borracha natural homogeneizada. c) adição do óxido de zinco. d) borracha natural homogeneizada com acido esteárico e óxido de zinco .....

FIGURA 15 - Placa de borracha recebendo pó de borracha de pneus inservíveis de automóvel em um misturador aberto (cilíndrico) tipo calandra 68

FIGURA 16 - Adição dos aceleradores na placa de borracha em um misturador aberto (cilíndrico) tipo calandra 68

FIGURA 17 - Vulcanizadora Equipamenta, tipo EQ - CV1

FIGURA 18 - Processo de corte dos corpos de prova 70 
FIGURA 19 - Corpos de prova submetidos à irradiação por feixes de elétrons, nas doses de $200 \mathrm{kGy}, 400 \mathrm{kGy}$ e $600 \mathrm{kGy}$ 70

FIGURA 20 - Termobalança TGA-50 da Shimadzu, Tóquio, Japão 71

FIGURA 21 - Calorímetro exploratório diferencial DSC-50 da Shimadzu, Tóquio, Japão 72

FIGURA 22 - FTIR Spectrum 400 da Perkin Elmer 72

FIGURA 23 - Evaporadora da marca Baltec Union, modelo SCD 050 73

FIGURA 24 - Microscópio Eletrônico de Varredura marca Philips, modelo LX 30 .73

FIGURA 25 - Microscópio Eletrônico de Varredura, formato Tabletop da marca HITACHI, modelo TM 3000

FIGURA 26 - Equipamento de ensaios mecânicos: Dinamômetro da marca INSTRON, modelo 5567

FIGURA 27 - Curvas termogravimétricas obtidas em atmosfera dinâmica de ar para as amostras de grânulos de pneus inservíveis de automóvel, não irradiada e irradiadas nas doses de 200kGy, 400kGy e 600kGy, sob razão de aquecimento de $10^{\circ} \mathrm{C} / \mathrm{min}$ desde a temperatura ambiente até $600^{\circ} \mathrm{C}$

FIGURA 28 - Curvas termogravimétricas obtidas em atmosfera dinâmica de $\mathrm{N}_{2}$ para a amostra de grânulos de pneus inservíveis de automóvel, não irradiada e irradiadas com doses de 200kGy, 400kGy e 600kGy 76

FIGURA 29 - Curva DSC obtida em atmosfera dinâmica de $\mathrm{N}_{2}$ para a amostra de grânulos de pneus inservíveis de automóvel não irradiada 78

FIGURA 30 - Curva DSC obtida em atmosfera dinâmica em $\mathrm{N}_{2}$ para a amostra de grânulos de pneus inservíveis de automóvel irradiada na dose de 200kGy

FIGURA 31 - Curva DSC obtida em atmosfera dinâmica em $\mathrm{N}_{2}$ para a amostra de grânulos de pneus inservíveis de automóvel irradiada na dose de 400kGy 79 FIGURA 32 - Curva DSC obtidas em atmosfera dinâmica em $\mathrm{N}_{2}$ para a amostra de grânulos de pneus inservíveis de automóvel irradiada na dose de 600kGy..... 80

FIGURA 33 - Ensaios mecânicos de deformação máxima na ruptura das amostras de borracha sem pó de pneus inservíveis não irradiadas e irradiadas nas doses de 200kGy, 400kGy e 600kGy

FIGURA 34 - Ensaios mecânicos de deformação máxima na ruptura das amostras de borracha com $10 \%$ de pó de pneus inservíveis não irradiadas e irradiadas nas doses de 200kGy, 400kGy e 600kGy ..... 82 
FIGURA 35 - Ensaios de deformação máxima na ruptura das amostras de borracha com $30 \%$ de pó de pneus inservíveis não irradiadas e irradiadas nas doses de 200kGy, 400kGy e $600 \mathrm{kGy}$

FIGURA 36 - Ensaios mecânicos de deformação máxima na ruptura das amostras de borracha com $50 \%$ de pó de pneus inservíveis não irradiadas e irradiadas nas doses de 200kGy, 400kGy e 600kGy ..... 83

FIGURA 37 - Variação da deformação máxima na ruptura das amostras não irradiadas e irradiadas nas doses de 200kGy, 400kGy e 600kGy com o aumento da concentração de pó de borracha de pneus inservíveis

FIGURA 38 - Espectros de absorção na região do infravermelho para as amostras de grânulos de pneus inservíveis de automóvel não irradiada e irradiada na dose de 200kGy 85 FIGURA 39 - Espectros de absorção na região do infravermelho para as amostras de grânulos de pneus inservíveis de automóvel não irradiada e irradiada na dose de 400kGy 86 FIGURA 40 - Espectros de absorção na região do infravermelho para as amostras de grânulos de pneus inservíveis de automóvel não irradiada e irradiada na dose de 600kGy 86 FIGURA 41 - Imagens obtidas por MEV dos grânulos de borracha de pneus inservíveis para aumento de 32 vezes: a) NI, b) $200 \mathrm{kGy}$, c) $400 \mathrm{kGy}$ e d) $600 \mathrm{kGy}$

FIGURA 42 - Imagens obtidas por MEV dos grânulos de borracha de pneus inservíveis para aumento de 100 vezes: a) NI, b) 200kGy, c) 400kGy e d) 600kGy 88 FIGURA 43 - Imagens obtidas por MEV dos grânulos de borracha de pneus inservíveis para aumento de 500 vezes: a) NI, b) $200 \mathrm{kGy}$, c) $400 \mathrm{kGy}$ e d) $600 \mathrm{kGy}$ 88 FIGURA 44 - Imagens obtidas por MEV dos grânulos de borracha de pneus inservíveis para aumento de 1000 vezes: a) NI, b) 200kGy, c) 400kGy e d) 600kGy FIGURA 45 - Imagens obtidas por MEV dos corpos de prova, sem pó e com pó de borracha de pneus inservíveis não irradiados para aumento de 500 vezes: a) sem pó, b) $10 \%$ pó, c) $30 \%$ pó e d) $50 \%$ pó

FIGURA 46 - Imagens obtidas por MEV dos corpos de prova, sem pó e com pó de borracha de pneus inservíveis não irradiados para aumento de 1000 vezes: a) sem pó, b) $10 \%$ pó, c) $30 \%$ pó e d) $50 \%$ pó

FIGURA 47 - Imagens obtidas por MEV dos corpos de prova, sem pó e com pó de borracha de pneus inservíveis irradiados com dose de 200kGy para aumento de 500 vezes: a) sem pó, b) $10 \%$ pó, c) $30 \%$ pó e d) $50 \%$ pó . .91 
FIGURA 48 - Imagens obtidas por MEV dos corpos de prova, sem pó e com pó de borracha de pneus inservíveis irradiados com dose de 200kGy para aumento de 1000 vezes: a) sem pó, b) $10 \%$ pó, c) $30 \%$ pó e d) $50 \%$ pó

FIGURA 49 - Imagens obtidas por MEV dos corpos de prova, sem pó e com pó de borracha de pneus inservíveis irradiados com dose de 400kGy para aumento de 500 vezes: a) sem pó, b) $10 \%$ pó, c) $30 \%$ pó e d) $50 \%$ pó 92 FIGURA 50 - Imagens obtidas por MEV dos corpos de prova, sem pó e com pó de borracha de pneus inservíveis irradiados com dose de 400kGy para aumento de 1000 vezes: a) sem pó, b) $10 \%$ pó, c) $30 \%$ pó e d) $50 \%$ pó

FIGURA 51 - Imagens obtidas por MEV dos corpos de prova, sem pó e com pó de borracha de pneus inservíveis irradiados com dose de 600kGy para aumento de 500 vezes: a) sem pó, b) $10 \%$ pó, c) $30 \%$ pó e d) $50 \%$ pó 93 FIGURA 52 - Imagens obtidas por MEV dos corpos de prova, sem pó e com pó de borracha de pneus inservíveis irradiados com dose de 600kGy para aumento de 1000 vezes: a) sem pó, b) $10 \%$ pó, c) $30 \%$ pó e d) $50 \%$ pó 94 


\section{LISTA DE TABELAS}

TABELA 1 - Exemplo de composição de borracha de pneu, porcentagem utilizada e finalidade de adição dos componentes.

TABELA 2 - Composição típica usada na produção de borracha de pneus para veículos leves

TABELA 3 - Propriedades físicas medidas em análise térmica, técnica derivada e abreviatura recomendada pela ICTAC (GIOLITO, IONASHIRO, 1988).

TABELA 4 - Exemplos das principais características de microscópios ópticos (MO) e eletrônicos convencionais, com o intuito de comparação .59

TABELA 5 - Comparação em porcentagem (\%) das perdas de massa das amostras não irradiada e irradiadas, em atmosfera dinâmica de ar, com doses de radiação conforme o aumento da temperatura ambiente até $600^{\circ} \mathrm{C}$. 76

TABELA 6 - Comparação em porcentagem (\%) das perdas de massa das amostras de pneus inservíveis de automóvel, não irradiada e irradiadas, em atmosfera dinâmica de $\mathrm{N}_{2}$ com diferentes doses de radiação com o aumento da temperatura ambiente até $600^{\circ} \mathrm{C} \ldots . . .77$ TABELA 7 - Valores médios em (\%) dos ensaios mecânicos de deformação máxima na ruptura das amostras de borracha com pó (10, 30 e 50\%) e sem pó de pneus inservíveis irradiadas e não irradiadas

TABELA 8 - Deformação máxima na ruptura (\%) para as amostras sem pó e com 10\%, $30 \%$ e $50 \%$ de pó de pneus inservíveis irradiadas e não irradiadas 


\section{LISTA DE SIGLAS E ABREVIAÇÕES}

ANIP - Associação Nacional de Indústria de Pneumáticos

ASTM - American Society for Testing and Material Standards

ATR - Reflectância total atenuada

BR - Borracha de butadieno

CCTM - Centro de Ciência e Tecnologia de Materiais

CNEN - Comissão Nacional de Energia Nuclear

CONAMA - Conselho Nacional do Meio Ambiente

$\mathrm{CR}$ - Borracha de policloropreno

CTR - Centro de Tecnologia das Radiações

DPG - N, N'- Difenilguanidina

DSC - Calorimetria exploratória diferencial

DTG - Termogravimetria derivada

DTA - Análise térmica diferencial

$\mathrm{eV}$ - elétron volt

FTIR - Espectroscopia de absorção na região do infravermelho com transformada de Fourier

Gy - Gray

ICTAC - International Confederation for Thermal Analysis and Calorimetry

IPEN - Instituto de Pesquisas Energéticas e Nucleares

kGy - quilo Gray

kGy/s - quilo Gray por segundo

$\mathrm{keV}$ - quilo elétron volt

LINAC - aceleradores de elétrons lineares

MBTS - Mercapto Benzotiazol Sulfenamina

MEV - Microscopia Eletrônica de Varredura

$\mathrm{MeV}$ - mega elétron volt

$\mathrm{mg}$ - miligramas

mm - milímetro

$\mathrm{M}_{\mathrm{n}}$ - Massa molar numérica média

NBR - Copolímero de butadieno e acrilonitrila

NR - Borracha natural

$\mathrm{NF}$ - Negro de fumo

phr - Partes por 100 de borracha, "per hundred of rubber" 
RF - Radio Frequência

SBR - Copolímero de estireno e butadieno

$\mathrm{T}_{\mathrm{A}}$ - Temperatura da amostra

TG - Termogravimetria

TGA - Analisador termogravimétrico

TMTD - Dissulfeto Tetrametil Tiuran 


\section{LISTA DE SÍMBOLOS}

$\Delta \mathrm{m}$ - Variação de massa

T - Tempo

$\mathrm{T}_{\mathrm{R}}$ - Temperatura da referência

$\mathrm{T}_{\mathrm{m}}$ - Temperatura de fusão cristalina

$\mathrm{T}_{\mathrm{g}}-$ Temperatura de transição vítrea

$\mathrm{T}_{\max }-$ Temperatura máxima

$\mathrm{T}_{\text {onset }}-$ Temperatura inicial

$\mathrm{T}_{\text {endset }}$ - Temperatura final extrapolada do evento térmico

$\mathrm{T}_{\text {pico }}-$ Temperatura de pico

$\mathrm{T}_{\text {inicial }}$ - Temperatura inicial

$\mathrm{T}_{\text {final }}-$ Temperatura final

$\alpha-$ alfa

$\beta$ - beta

$\Delta \mathrm{H}_{\mathrm{F}}-$ entalpia de fusão

$\gamma$-gama

$\mu \mathrm{m}-$ micrometro

$\%$ - Por cento

$\% / \mathrm{mol}$ - Por cento por mol

${ }^{\circ} \mathrm{C}$ - Graus Celsius

${ }^{\circ} \mathrm{C} / \mathrm{m}$ - Graus Celsius por minuto 


\section{INTRODUÇÃO}

A reciclagem desperta a importância da preservação dos recursos naturais, evitando o desperdício dos mesmos e a poluição dos rios, ou seja, toda alteração das propriedades naturais do meio ambiente que seja prejudicial à saúde, à segurança ou ao bem estar da população sujeita aos efeitos da poluição causada por agentes de qualquer espécie. A reciclagem é a recuperação de resíduos mediante uma série de operações, que permitem, em alguns casos, que materiais processados sejam reaproveitados como matéria prima para beneficiar ou para diminuir a quantidade dela virgem quando comercializada, podendo baratear o seu custo (MANO, 2005; WIEBECK, HARADA, 2002).

A reciclagem inclui as etapas de separação, que são as atividades intermediárias as quais colocam os resíduos no ponto de serem transformados, sendo esta a etapa de transformação no reprocessamento industrial (WIEBECK, HARADA, 2002).

Pela sua própria condição temática, o processo de reciclagem, seu desenvolvimento e a tecnologia utilizada tem levado a discussão e ao trabalho de diversos pesquisadores, em múltiplas áreas do conhecimento científico, empresários e profissionais da reciclagem (WIEBECK, PIVA, 2004).

Um dos maiores problemas enfrentados na preservação do meio ambiente é o gerenciamento dos resíduos de materiais poliméricos antes e após o consumo, ou seja, sobras de produção e artefatos já usados.

Os polímeros são constituídos de macromoléculas orgânicas, sintéticas ou naturais. Os plásticos e as borrachas butílicas são exemplos de polímeros sintéticos, enquanto o couro, a seda, o chifre, o algodão, a lã, a madeira e a borracha natural são constituídos de macromoléculas orgânicas naturais (PADILHA, 2000).

Após o seu uso como produto, esses materiais são encontrados em lixões, aterros, ou mesmo em nosso cotidiano, em rios, lagos e lagoas, geralmente em forma de embalagens de alimentos, sacolas e garrafas, incluem-se também os pneus (WIEBECK, ESPER, FEIJÓ, 2002). Dentre todos esses materiais o que foi utilizado para estudo neste trabalho foi a borracha de pneus automotivos inservíveis.

Pneu inservível é aquele já usado que apresenta danos irreparáveis em sua estrutura não se prestando mais a rodagem ou a reforma, ou seja, não podem ser mais recauchutados (RECICLANIP, 2013).

A maioria desses pneus velhos é jogada em aterros sanitários, lixões, terrenos e áreas não controladas. Os aterros industriais controlados e licenciados são aqueles 
utilizados pelas indústrias, como por exemplo, a reutilização em indústrias de borracha, como a Borcol Indústria de Borracha Ltda., que produz tapetes de carros utilizando, em parte, a borracha recuperada de pneus.

Pneus são materiais normalmente, constituídos por vários tipos de borracha, borracha natural, borracha sintética, borracha butílica; cargas como, negro de fumo, e reforços tais como, nylon e malha de aço (WIEBECK, ESPER, FEIJÓ, 2002).

Os pneus são considerados um dos principais componentes dos automóveis por serem a combinação perfeita de matéria prima, tais como, derivados de petróleo, borracha natural, aço e produtos químicos. As concentrações de borrachas natural (NR), de butadieno (BR) e de copolímero de estireno e butadieno (SBR), variam de acordo com o fabricante e com a utilização do pneu. Os pneus de automóveis representam $80 \%$ do total da frota e os pneus de caminhão representam 20\% (BILLITER, 1996).

Nos pneus de automóveis de passeio, predominam os derivados de petróleo e produtos químicos, constituindo $36 \%$, a borracha natural representa $36 \%$, o material metálico (ou aço) conta com 18\% e 10\% correspondem a outros componentes. Esses são projetados para suportar altas velocidades, enquanto que para caminhões de carga preveem suportar mais peso, em razão disto, a quantidade de borracha natural nos pneus de caminhão ultrapassa os 40\% (PORTAL SÃO FRANCISCO, 2011).

Os pneus inservíveis são materiais que vêm chamando a atenção de ambientalistas e da comunidade acadêmica há muito tempo. Somente nos EUA são gerados 250 milhões de pneus inservíveis todos os anos, que somados aos anos anteriores, alcança a casa de bilhões de unidades (BILLITER, 1996).

No Brasil, o montante de pneus/ano colocados no mercado chega a 68 milhões. Dados da Associação Nacional da Indústria de Pneumáticos (ANIP) indicam que existem espalhados no país cerca de 900 milhões de pneus inservíveis, sendo que somente $50 \%$ do total são descartados de forma adequada (ANIP, 2011).

Vários métodos para a destinação ambientalmente correta estão sendo desenvolvidos para buscar resolver o problema dos pneus inservíveis no Brasil, por exemplo, eles são reaproveitados de diversas formas, como combustível alternativo para as indústrias de cimento, na fabricação de solados de sapato, em borrachas de vedação, dutos pluviais, para quadras poliesportivas, pisos industriais, asfalto-borracha e tapetes para automóveis. A RECICLANIP, entidade voltada para a coleta e destinação de pneus inservíveis, coletou e destinou de forma ambientalmente correta 107.104 toneladas de 
pneus inservíveis no primeiro quadrimestre de 2011, o equivalente a 214 milhões de unidades de pneus de carros de passeio (ANIP, 2012).

O elastômero SBR (copolímero de estireno e butadieno) é um dos elastômeros mais utilizados na confecção de pneus, contendo $25 \%$ em peso, de estireno. Outras borrachas usadas na confecção de pneus são o poli (cis-isopreno), que é a borracha natural (NR), poli (cis-isopreno) sintético e poli (cis-butadieno) (SEGRE, 1999; WILLIAN, BESLER, TAYLOR, 1990). Um exemplo de composição de borracha de pneu é apresentado na TAB. 1.

TABELA 1 - Exemplo de composição de borracha de pneu, porcentagem utilizada e finalidade de adição dos componentes

\begin{tabular}{ccc} 
Componentes & Porcentagem $(\%)$ & Composição/Finalidade \\
\hline SBR & 62,1 & $-\left[\left[-\mathrm{CH}_{2}-\mathrm{CH}=\mathrm{CH}-\mathrm{CH}_{2}-\mathrm{CH}_{2}-\mathrm{CH}-\left(\mathrm{CH}_{6} \mathrm{H}_{5}\right)\right]_{\mathrm{n}}{ }^{-}\right.$ \\
\hline negro de fumo & 31,5 & $\begin{array}{r}\text { fortificar a borracha, aumentar a resistência à } \\
\text { abrasão, dissipar calor }\end{array}$ \\
\hline óleo modificado & 1,9 & $\begin{array}{c}\text { mistura de hidrocarbonetos aromáticos/ } \\
\text { amolecer a borracha, dar trabalhabilidade }\end{array}$ \\
\hline óxido de zinco & 1,9 & $\begin{array}{c}\text { controlar processo de vulcanização, aumentar } \\
\text { propriedades da borracha }\end{array}$ \\
\hline Ácido esteárico & 1,2 & $\begin{array}{c}\text { controlar processo de vulcanização, aumentar } \\
\text { propriedades físicas da borracha }\end{array}$ \\
\hline enxofre & 1,1 & $\begin{array}{c}\text { fazer a reticulação entre as cadeias } \\
\text { poliméricas, prevenir excessivas deformações } \\
\text { a altas temperaturas }\end{array}$ \\
\hline aceleradores & 0,7 & $\begin{array}{r}\text { composto organo-enxofre / catalisar a } \\
\text { vulcanização }\end{array}$
\end{tabular}

Fonte: (SEGRE, 1999; WILLIAN, BESLER, TAYLOR, 1990; DAWKINS, 1986).

Em razão da sua composição química, os pneus são combustíveis e queimam a altas temperaturas, produzindo grandes quantidades de fumaça negra e óleos que penetram e contaminam solos e lençóis d'água. Além disso, o acúmulo de pneus usados a céu aberto gera focos de procriação de mosquitos, tornando-se um problema maior para a saúde pública no controle de epidemias (ELDIN, PIEKARSKI, 1993). 
Conforme a legislação vigente os pneus dispostos inadequadamente constituem passivo ambiental, que podem resultar em sério risco ao meio ambiente e à saúde pública (WIEBECK, ESPER, FEIJÓ, 2002; BILLITER, 1996).

\subsection{Resolução do Conselho Nacional do Meio Ambiente (CONAMA) de 2009}

Em razão de encontrar um meio eficaz para a destinação de pneus inservíveis de automóvel foi criada a resolução ${ }^{\circ} 416$ de 30 de Setembro de 2009 publicada no Diário Oficial da União em 1 de outubro de 2009, editada pelo Conselho Nacional do Meio Ambiente - CONAMA, do Ministério do Meio Ambiente, que dispõe sobre a prevenção à degradação ambiental causada por pneus inservíveis e sua destinação ambientalmente adequada, e dá outras providências (PORTAL SÃO FRANCISCO, 2011; RECICLANIP, 2013).

Pela referida norma, os fabricantes e os importadores de pneus novos, com peso unitário superior a 2,0kg, ficam obrigados a coletar e dar destinação adequada aos pneus inservíveis existentes no território nacional. Ainda de acordo com esta resolução, para cada pneu novo comercializado para o mercado de reposição, as empresas fabricantes ou importadoras deverão dar destinação adequada a um pneu inservível.

Neste trabalho, foi utilizada a radiação ionizante proveniente de um acelerador de elétrons, na modificação ou degradação como método alternativo para a reciclagem de pneus inservíveis.

A radiação ionizante (raios gama ou feixe de elétrons) é utilizada para a modificação de polímeros, fibras, macromoléculas naturais, desenvolvimento de novos materiais compósitos e esterilização de produtos médicos entre outros. A radiação ionizante por feixe de elétrons, ao interagir com os polímeros, transfere energia aos átomos da cadeia polimérica, provocando modificações na sua estrutura e consequentemente nas suas propriedades físico-químicas. Os estudos realizados nas últimas décadas mostraram que a modificação das propriedades dos materiais poliméricos por radiação ionizante é o resultado das reações de reticulação e cisão que ocorrem simultaneamente durante a irradiação e da compatibilização e estabilização morfológica do material (CLOUGH, 1996). Estas reações são concorrentes e a predominância de uma sobre a outra depende do material, ou seja, da estrutura química do polímero, das condições de irradiação e de outros fatores específicos do material polimérico que irá absorver a energia, como o histórico do 
seu processamento, grau de cristalinidade e aditivos presentes, entre outros (CLOUGH, 1996; SOUZA, 2009). 


\section{OBJETIVO}

Este trabalho tem por objetivo:

- Utilizar a radiação ionizante para a degradação de amostras de grânulos de pneus inservíveis de automóvel e sua caracterização;

- Incorporar o pó do pneu inservível em uma matriz elastomérica, irradiá-la e caracterizá-la. 


\section{REVISÃO DA LITERATURA}

\subsection{Pneus}

O pneu é o componente de interface entre o veículo e o solo, transmitindo e recebendo esforços (provenientes de acelerações longitudinais, laterais e impactos) e sendo também responsável por suportar carga (VIEIRA, 2009; PINHEIRO, 2001). O pneu é composto por diversos elementos constitutivos, os processos de recauchutagem de pneus, baseiam-se na substituição de um destes elementos, ou seja, a banda de rodagem, conforme mostrado na FIG. 1. A função e/ou composição de cada um desses elementos é:

-Banda de rodagem: parte do pneu que fica em contato direto com o solo. Seus desenhos possuem partes cheias chamadas de biscoitos ou blocos e partes vazias conhecidas como sulcos e oferecem aderência, tração, estabilidade e segurança ao veículo;

- Carcaça: composta por lonas de poliéster, nylon ou aço. Retém o ar sobre pressão que suporta o peso total do veículo. Os pneus radiais possuem ainda as cintas que complementam sua resistência;

-Talões: constituem-se internamente de arames de aço de grande resistência e tem por finalidade manter o pneu preso ao aro da roda;

-Parede lateral: revestidas por uma mistura de borracha com alto grau de flexibilidade e alta resistência à fadiga;

-Cintas (lonas): garantem a área de contato necessária entre o pneu e o solo;

-Ombro: apoia o pneu nas curvas e manobras;

-Nervura central: proporciona um contato "circunferencial” do pneu com o solo. 


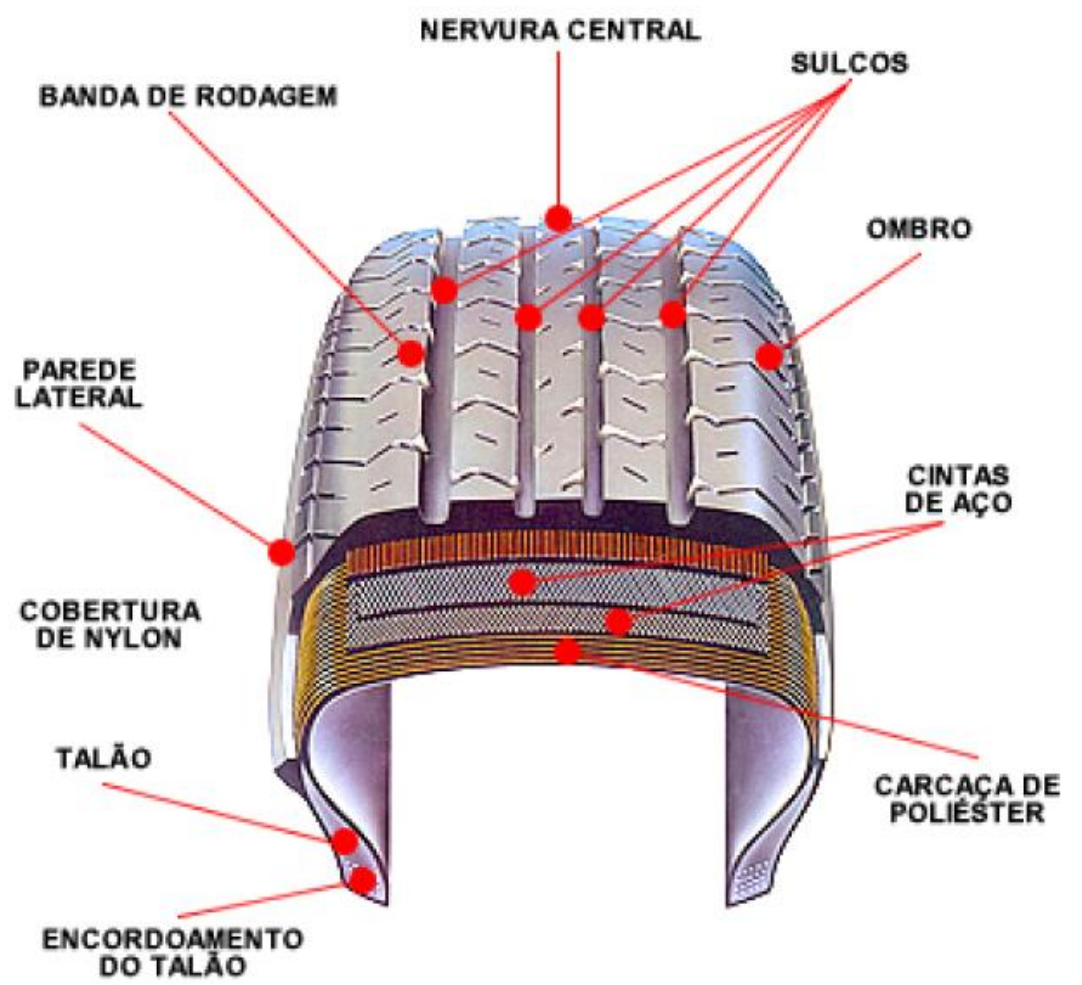

FIGURA 1- Constituição de um pneu

O pneu é formado como um cilindro sobre um tambor retrátil onde são aplicadas as camadas de cordéis impregnados na borracha apropriada, de modo que uma camada amarra os fios metálicos numa direção e a outra camada amarra-os na direção transversal. Os cabos metálicos em uma borracha resistente e dura são "costurados" ao pneu mediante a dobragem das extremidades das lonas (RODRIGUES, 2008).

Finalmente, aplica-se a banda formada por extrusão e as extremidades são soldadas. O tambor que forma o pneu é retirado e o pneu cilíndrico é removido e colocado numa prensa. É inserido no cilindro um saco de borracha (usualmente feito de borracha butílica) fixando a uma haste, que é inflado dentro do tubo, simultaneamente o molde da prensa é fechado e o pneu assume a sua forma cilíndrica. Aplica-se aquecimento ao molde e vapor ao saco interno. A borracha em excesso escapa por orifícios de drenagem e depois do tempo de vulcanização a uma temperatura pré-selecionada o pneu está pronto (RODRIGUES, 2008).

A palavra vulcanização, sugerida por Willian Brockedown, vem de Vulcano (Deus do Fogo). E a vulcanização da borracha pode ser definida quando o material sofre transformação em suas propriedades plásticas para elásticas em virtude das ligações 
cruzadas formadas entre cadeias dos elastômeros e agentes de vulcanização (GOMES, 2008; MISAWA, 2011).

O número de automóveis fabricados tem mantido um ritmo de crescimento em todo mundo e há um aumento do consumo de pneus novos a cada ano. Anualmente, o número de pneus descartados é de aproximadamente 1 bilhão de unidades em todo mundo, soma-se a expectativa de um aumento em torno de $2 \%$ por ano, então a eliminação destes acessórios tornaram-se um importante ponto de discussão, pois o pneu é considerado resíduo sólido. Menos de $7 \%$ do volume total de pneus produzidos são reciclados (excluindo a reutilização, recauchutagem ou a combustão) (ALVES, 2011; FERRER, 1997).

O pneu é considerado um resíduo sólido pela norma NBR 10.004 (1987) da ABNT, substituída pela norma NBR 10004 (2004) que classifica os resíduos sólidos em três categorias (RODRIGUES, 2008; CETESB, 2013):

- Resíduos classe I - Perigosos: Resíduos sólidos ou mistura de resíduos que, em função de suas características de inflamabilidade, corrosividade, reatividade, toxicidade e patogenicidade, podem apresentar riscos à saúde pública, provocando ou contribuindo para um aumento de mortalidade ou incidência de doenças e/ou apresentar efeitos adversos ao meio ambiente, quando manuseados ou dispostos de forma inadequada.

- Resíduos classe II - Não Inertes: Resíduos sólidos ou mistura de resíduos sólidos que não se enquadram na classe I (perigosos) ou na classe III (inertes). Estes resíduos podem ter prioridades, tais como: combustibilidade, biodegradabilidade ou solubilidade em água.

- Resíduos classe III - Inertes: Resíduos sólidos ou mistura de resíduos sólidos que, submetidos a testes de solubilização, não tenham nenhum de seus constituintes solubilizados em concentrações superiores aos padrões de portabilidade de águas, excetuando-se os padrões: aspecto, cor, turbidez e sabor. Como por exemplo, destes materiais, pode-se citar rochas, tijolos vidros, certos plásticos e borrachas que não são decompostos prontamente.

Dentre as informações da NBR 10.004 (1987), os pneus inservíveis podem ser enquadrados como Resíduos Classe II - Não Inertes, considerando que apresentam problemas ambientais em função de sua débil biodegradabilidade e sua alta combustibilidade, tornando-se um material de difícil controle após ser submetido ao fogo. Esta norma foi substituída pela NBR 10004 (2004) e os pneus foram classificados como Classe II B - Inertes código A008 (RODRIGUES, 2008; CETESB, 2013). 
Os resíduos sólidos são também classificados de acordo com seus diferentes graus de biodegradabilidade (RODRIGUES, 2008; BIDONE, 1999; GOMES, 1989).

a) Facilmente degradáveis: é o caso de matéria orgânica presente nos resíduos sólidos de origem urbana;

b) Moderadamente degradáveis: papel, papelão e outros produtos celulósicos;

c) Dificilmente degradáveis: trapos, couro (tratado), borracha e madeira;

d) Não degradáveis: vidro, plásticos, pedras, etc.

As borrachas são consideradas resíduos classe II devido a algumas das matérias prima normalmente utilizadas em compostos de borracha, esses compostos são:

a) Elastômeros: copolímero de estireno e butadieno (SBR) produzido por emulsão a quente e a frio;

b) Acelerador orgânico de vulcanização: N, N'-Difenilguanidina (DPG);

c) Agente auxiliar de processo: resina hidrocarbônica aromática de petróleo;

b) Carga: negro de fumo; grafite e cal hidratada;

c) Ativador de vulcanização: óxido de zinco, (MISAWA, 2011).

Um veículo automotor leve possui de $30-40 \mathrm{~kg}$ de borracha e aço na forma de pneus, levando-se em consideração que os pneus apresentam vida útil média de 2 a 3 anos, cada automóvel gera anualmente cerca de 10kg de pneus usados (ALVES, 2011; FERRER, 1997).

Hoje a maior parte dos pneus é feita de 10\% de borracha natural (látex), $30 \%$ de borracha sintética (proveniente do petróleo), 60\% de aço e tecidos (tipo lona), que servem para fortalecer ainda mais a estrutura, esta estrutura tem por objetivo atribuir-lhe as características necessárias ao seu desempenho e segurança (RODRIGUES, 2008).

A borracha empregada na fabricação de pneus é composta por cerca de $60 \%$ de butadieno estireno, SBR, um polímero termofixo. Por se tratar de um polímero termofixo ele não pode ser reprocessado de forma direta como os termoplásticos, portanto a reciclagem deste material requer técnicas especiais que demandam elevados investimentos. Para veículos leves na TAB. 2 é apresentada uma composição típica da borracha de pneus (GOMES, 2008; ALVES, 2011). 
TABELA 2 - Composição típica usada na produção de borracha de pneus para veículos leves

\begin{tabular}{cc}
\hline Composto & Porcentagem \\
\hline SBR & 62,1 \\
Negro de fumo & 31,0 \\
Óleos & 1,9 \\
Óxido de zinco & 1,9 \\
Ácido Esteárico & 1,2 \\
Enxofre & 1,1 \\
Aceleradores (MBTS, TMDT). & 0,7
\end{tabular}

Fonte: ALVES, 2011; CAPONERO, TENÓRIO, 2001.

Por ser de difícil composição, os materiais que compõem a estrutura dos pneus torna a disposição final destes materiais ainda mais complexa. Para resolver esta questão, tem-se que mudar a óptica de destinação final adequada para a melhor tecnologia de tratamento disponível, ambientalmente segura e economicamente viável para os pneus inservíveis (ALVES, 2011).

\subsubsection{Matérias primas}

A borracha de pneu é composta de matérias primas, essenciais para a sua formulação, como a borracha natural (NR) pouco empregada em relação à borracha sintética copolímero estireno-butadieno (SBR), as cargas como o negro de fumo, aditivos e aceleradores como óxido de zinco, ácido esteárico, enxofre, Mercapto Benzotiazol Sulfenamina (MBTS), Dissulfeto Tetrametil Tiuran (TMTD) entre os óleos e outros.

\subsubsection{Borracha Natural (NR)}

A borracha natural já era usada no século XI por Maias (Pokatok) que viviam como índios antes mesmo do descobrimento da América. Em 1525, Pietro d'Anghiera relatou ter visto índios mexicanos jogarem com bolas elásticas, eles retiravam o látex das árvores de seringueiras e o secavam no calor de fogueiras (GOMES, 2008).

Pierre Macquer indicou o modo de fabricação de tubos flexíveis de borracha. A primeira fábrica de borracha no mundo foi estabelecida perto de Paris em 1803 e a 
primeira na Inglaterra por Thomas Hancock em 1815 o que tornou um dos maiores fabricantes de colchões e capas impermeáveis do Reino Unido (GOMES, 2008).

Desde 1826, a estrutura química da borracha natural vem sendo estudada, Faraday determinou a fórmula empírica do isopreno, e este composto foi identificado como um dos componentes principais dos produtos de pirólise da borracha. Em 1875, G. Bourchardt sugeriu que a borracha natural fosse um polímero isopreno e realizou a polimerização do isopreno entre 1879 e 1882, obtendo produtos de propriedades semelhantes à borracha natural (GOMES, 2008; LOADMAN, 2000). Houveram várias tentativas de desenvolver um processo para o melhoramento das qualidades da borracha (incorporação de ácido nítrico, por exemplo).

Em 1839 Goodyear descobriu acidentalmente a vulcanização deixando cair borracha e enxofre casualmente no fogão. Em razão da descoberta, a demanda por este produto se multiplicou pelo mundo (GOMES, 2008).

Hancock, em 1842, com base na borracha vulcanizada de Goodyear, procurou e encontrou o segredo da vulcanização, fazendo enorme fortuna (GOMES, 2008).

Payer estudou as propriedades físicas da borracha vulcanizada, do mesmo modo que Grahan, Wiesner e Gerard. Desde então a borracha passou a ocupar um lugar de destaque no mercado mundial (GOMES, 2008).

O mais importante dos látices naturais é retirado da seringueira (Hevea brasiliensis da família Euphorbiacea), dela se extrai o látex. Para esta extração, são feitos pequenos cortes no caule (tronco) da árvore podendo captar a seiva de cada árvore retirando entre 50 a $100 \mathrm{~g}$ por dia como mostrado na FIG. 2. O látex da borracha natural um polímero isoprenóide - poli(1,4 cis isopreno) é utilizado para muitas aplicações tecnológicas.

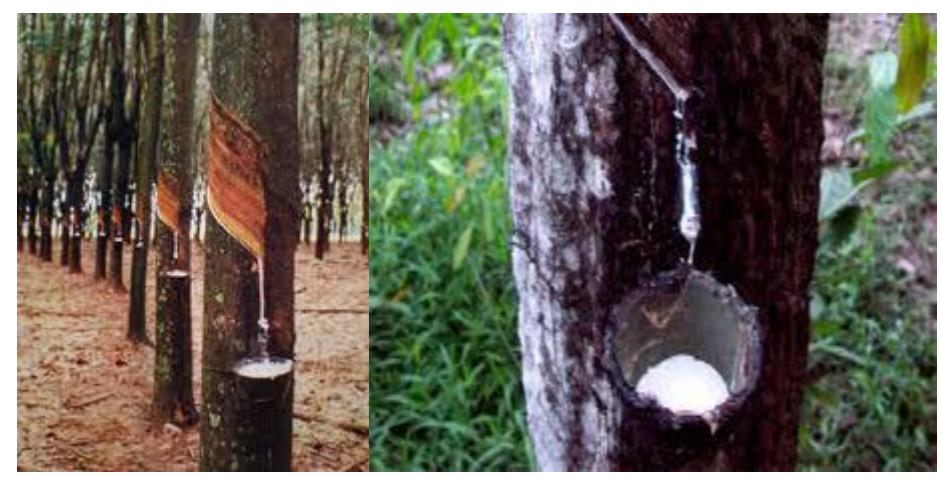

(a)

(b)

FIGURA 2 - Extração do látex. (a) cortes superficiais na seringueira, (b) látex sendo coletado 
Na composição do látex se encontra 35\% de hidrocarboneto destacando-se o 2metil-butadieno - 1,3- $\left(\mathrm{C}_{5} \mathrm{H}_{8}\right)_{\mathrm{n}}$ comercialmente conhecido como isopreno, o monômero da borracha, mostrado na FIG. 3.

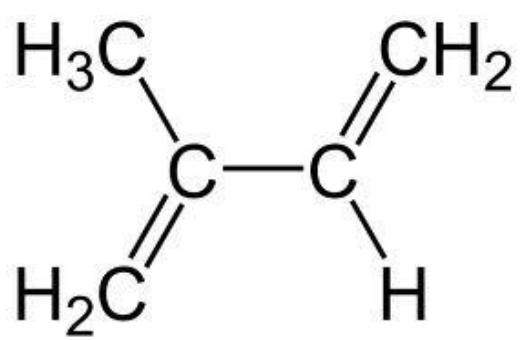

FIGURA 3 - Mero da cadeia polimérica da borracha natural: unidade repetitiva do poli( 1,4 cis isopreno)

O látex é praticamente neutro, com pH 7,0 a 7,2 mas quando exposto ao ar por um período de 12 a 24 horas o $\mathrm{pH}$ cai para 5,0 e ocorre a coagulação natural, formando poli(1,4 cis isopreno), representado por $\left(\mathrm{C}_{5} \mathrm{H}_{8}\right)_{\mathrm{n}}$, (n) é o grau de polimerização. Apresenta massa molar média de 600.000 a $950.000 \mathrm{~g} / \mathrm{mol}$. É constituído por substâncias tais como proteínas, lipídios, aminoácidos, água, hidrocarbonetos, entre outros (GOMES, 2008; TANAKA, 2001).

A borracha natural possui unidades repetitivas (mero) do isopreno que a constituem, se ligam por meio de ligações por meio dos átomos de carbono (1 e 4) num arranjo cabeça-calda, formando uma configuração cis, ou seja, os grupos laterais encontram-se todos no mesmo lado da cadeia. A regularidade micro-estrutural exerce importante papel sobre as propriedades da borracha natural, tais como elasticidade e deformação.

A borracha natural possui desvantagens como ser perecível e putrefável, por estar misturada a outras substâncias que não são a borracha e além de ser pegajosa e sensível a temperatura. Para melhorar as suas propriedades dentro das aplicações desejadas, após a coagulação e secagem seguida de aquecimento deve-se proceder à adição de cargas e aditivos homogeneamente na matriz, normalmente misturados e homogeneizados por meio de misturador fechado tipo Bambury (GOMES, 2008; NAUTON, 1961).

As principais cargas e aditivos empregados são o enxofre, óxido de zinco, ácido esteárico, aceleradores orgânicos, anti-ozonantes e antioxidantes, agentes de fluxo, 
plastificantes, esponjantes, cargas e minerais entre as quais se destacam a mica e o negro de fumo (GOMES, 2008; HERTZ, 1984; JENSEN, 1982; MORTON, 1975).

\subsubsection{Copolímero de estireno-butadieno (SBR)}

Com o avanço de novas tecnologias da indústria da borracha natural e o papel que assumiu para a civilização moderna, despertou o interesse pela descoberta da sua composição química e síntese, surgindo à necessidade de se obter um produto mais barato. O elastômero SBR - Copolímero de estireno e butadieno é o elastômero sintético que mais se expandiu no mundo. Ao lado da borracha natural (NR), divide cerca de 70 a $75 \%$ do mercado mundial dos elastômeros (GOMES, 2008; MISAWA, 2011).

O elastômero SBR surgiu na década de 1930, na Alemanha, com o nome de Buna S. Esse produto ainda era considerado de baixa qualidade se comparado com a NR, porém, o avanço da tecnologia serviu de base para a produção nos Estados Unidos na década seguinte (1940). Foi então desenvolvido e produzido em grande escala durante a Segunda Guerra Mundial, recebendo a denominação de GRS (Government RubberStyrene), sendo esse nome substituído por SBR ("Styrene-Butadiene Rubber") (SALTMAN, 1973; BRYDSON, 1988; GOMES, 2008; MISAWA, 2011).

Esse elastômero pode ser produzido por dois diferentes métodos de polimerização: emulsão ou solução. A principal diferença entre a SBR produzida por polimerização por emulsão e solução é em relação à linearidade e distribuição da massa molar. O elastômero SBR produzido por polimerização por emulsão apresenta uma distribuição de massa molar maior e um alto grau de ramificação, fatores que facilitam o seu processo de produção (SALTMAN, 1973; MISAWA, 2011).

O elastômero SBR pode ser produzido a partir de dois monômeros obtidos do petróleo: o butadieno $\left(\mathrm{CH}_{2}=\mathrm{CH}-\mathrm{CH}=\mathrm{CH}_{2}\right)$ e o estireno $\left(\mathrm{C}_{6} \mathrm{H}_{5}-\mathrm{CH}=\mathrm{CH}_{2}\right)$. A SBR pode ser copolimerizada com diferentes teores de estireno e butadieno, por exemplo, a SBR pode conter um teor de $23,5 \%$ de estireno, com os monômeros distribuídos aleatoriamente nas cadeias do polímero (MISAWA, 2011; BRYDSON, 1988).

A fórmula estrutural desse elastômero está mostrada na FIG. 4.

$$
-\left[\left[\mathrm{CH}_{2}-\mathrm{CH}=\mathrm{CH}-\mathrm{CH}_{2}\right]_{\mathrm{n}}-\mathrm{CH}_{2}-\mathrm{CH}\left(\mathrm{C}_{6} \mathrm{H}_{5}\right)\right]_{\mathrm{n}}{ }^{-}
$$

FIGURA 4 - Fórmula estrutural da borracha SBR (MISAWA, 2001; HIBBS, 1990) 
Além dos dois principais monômeros outros produtos são utilizados em menor quantidade, como os emulsificantes, modificadores, catalisadores, terminadores, agentes coagulantes, antioxidantes e antiozonantes (MISAWA, 2011).

\subsubsection{Cargas}

As cargas em forma de partículas finas têm sido utilizadas desde os primórdios da indústria da borracha.

No início as cargas eram utilizadas com o objetivo de reduzir o custo, porém, logo se percebeu que elas poderiam ser úteis como agentes de processo, reduzindo inchamento ("swelling") ou proporcionando maciez para produtos calandrados ou extrudados (MISAWA, 2011; BRYDSON, 1988).

Algumas cargas, como o óxido de zinco e o negro de fumo, foram originalmente utilizadas em virtude de suas colorações. Porém, estudos sistemáticos do efeito das cargas foram desenvolvidos a partir de 1891 por Heinzerling e Pahl na Alemanha, esses estudos mostraram o efeito ativador que o óxido de zinco proporcionava em processos de vulcanização (MISAWA, 2011; BOONSTRAN, 1973).

Em 1904, em Londres, Mote, Mathews e colaboradores utilizaram negro de fumo e descobriram que algumas partículas finas tinham o efeito reforçante em algumas propriedades como módulo, resistências à abrasão, ao rasgo e à tração (MISAWA, 2011).

As cargas particuladas são essencialmente divididas em dois grupos: cargas inertes e cargas de reforço. As cargas inertes (argilas, baritas, carbonatos, hidróxidos, sulfetos, entre outras) não possuem características de reforço, embora cargas com dimensões de partículas finas possam proporcionar algum reforço. Apesar disso, estas cargas aumentam a rigidez e podem auxiliar no controle de densidade e influenciam nas propriedades elétricas. O negro de fumo é a carga de reforço mais importante da indústria de borracha. Cargas brancas reforçantes como sílicas e silicatos, também estão disponíveis para uma utilização mais específica (MISAWA, 2011).

\subsubsection{Negro de fumo}

Esse material é produzido pela combustão incompleta de várias substâncias orgânicas sólidas, líquidas ou gasosas, porém atualmente é produzido principalmente a partir do petróleo ou gás natural (ALVES, 2011; MISAWA 2011). 
O negro de fumo é formado essencialmente por carbono elementar com partículas de estrutura molecular amorfas extremamente finas, apresentando uma área superficial alta em relação ao volume. O tamanho médio da partícula de negro de fumo disponível comercialmente varia de 10 a 500 nanômetros, atua diretamente nas propriedades físicas e mecânicas do polímero, reduz o custo, não aumenta de forma considerável a densidade e atua como pigmento (MISAWA, 2011; WIEBECK, ESPER, FEIJÓ, 2002).

\subsubsection{Ativador de vulcanização}

$\mathrm{O}$ óxido de zinco $(\mathrm{ZnO})$ é um pó branco em temperatura ambiente, quando aquecido apresenta-se um pouco amarelado. Seu ponto de fusão é de aproximadamente $1975^{\circ} \mathrm{C}$. Pode ser encontrado em ocorrências naturais ou obtido a partir de sulfetos, silicatos, carbonatos ou oxidação do zinco metálico (MISAWA, 2011). Nas reações de vulcanização do SBR utilizando o enxofre como agente de vulcanização, o óxido de zinco atua como catalizador, promovendo a ruptura do anel de enxofre, formando radicais ou íons, iniciando o processo de vulcanização (MISAWA, 2011; WIEBECK, ESPER, FEIJÓ, 2002).

\subsection{Radiação ionizante}

A radiação ionizante ou radiação de energia alta são termos usados para radiação eletromagnética, como as radiações proferidas por núcleos radioativos naturais ou artificiais, que são os raios gama $(\gamma)$ e raios $X$ produzidos no processo de freamento de elétrons de energia alta pela matéria, ou emissões de partículas alfa $(\alpha)$, beta $(\beta)$ ou feixes de partículas aceleradas (elétrons, prótons, dêuterons, entre outros). Tais radiações carregam energia suficiente para ionizar moléculas que apresentam potenciais de ionização entre $10 \mathrm{eV}$ e $15 \mathrm{eV}$ (O'DONNELL, SANGSTER, 1970; SWALLOW, 1960; VÉRTES, 2003; SOUZA, 2009).

O efeito primário de qualquer radiação ionizante é baseado na sua capacidade de excitar e ionizar moléculas e isto conduz à formação de radicais livres, o qual em seguida, inicia reações de polimerização, reticulação ou degradação. Feixes de elétrons provenientes de aceleradores com energia abaixo de $10 \mathrm{MeV}$, podem, portanto, iniciar quimicamente reações. Tipicamente, as reações iniciadas por radiação ionizante são extremamente rápidas e são concluídas em frações de segundos (DROBNY, 2010). 
As radiações ionizantes possuem energia de valor superior à energia da ligação química e perdem a sua energia principalmente pela interação com os elétrons orbitais das moléculas localizadas ao longo da sua trajetória, originando estados excitados ou ionizando-as e gerando íons ou radicais livres. A energia de ligação é a quantidade de energia necessária para romper a ligação (CLOUGH et al., 1996; DOLE, 1972; DROBNY, 2002). A quantidade de energia para romper a ligação deve ser superior à energia de ligação entre átomos.

A maioria das macromoléculas é sólida em temperatura ambiente (TA), a menos que a massa molar seja baixa. Assim, os radicais livres podem ficar aprisionados em TA e suas reações serem convenientemente estudadas na escala de tempo. Os radicais livres são formados no início e nas etapas subsequentes da radiólise e, por isso, são extremamente importantes para a química das radiações de macromoléculas (HEDVIG, 1972; KODAMA, 2010).

Os radicais livres são átomos ou moléculas que possuem um ou mais elétrons desemparelhados disponíveis para formar ligações químicas. São espécies muito reativas, geralmente, com um tempo de vida muito curto, em benefício da capacidade de gerar outros radicais, por reação com a molécula neutra, sendo o novo radical capaz de repetir o processo, estabelecendo assim, reações com intensidade rápida em cadeia.

A molécula pode ser ionizada quando a quantidade de energia transferida, originária da partícula incidente, é maior que o potencial de ionização da molécula, e pode ocorrer a excitação eletrônica, levando um elétron orbital de seu estado de menor energia (estado fundamental) para um estado de maior energia, tornando a molécula instável e reativa quimicamente. No caso em que a energia transferida, proveniente da partícula incidente, é maior que a energia de excitação e de ligação dos elétrons na molécula, esta será suficiente para arrancar um elétron do seu orbital, induzindo a uma carga positiva, isto é, ionizando a molécula.

A quantidade de energia absorvida pela matéria em virtude da interação com a radiação ionizante pode ser estimada, ou seja, a confirmação da dose total de radiação absorvida foi realizada por dosimetria, utilizando-se dosímetros de triacetato de celulose. $\mathrm{O}$ produto da química das radiações é expresso em $\mathrm{G}(\mathrm{X})$, o qual representa o número de moléculas modificadas ou formadas por $100 \mathrm{eV}$ de energia absorvida (TABATA, 1981; CLEGG, 1992). Na química das radiações ionizantes os fótons e as partículas de energia alta não são seletivos e podem reagir com as moléculas que estão ao longo de suas trajetórias, surgindo, estados ionizados e excitados, em alta concentração, particularmente 
nas fases líquidas e sólidas. O resultado da absorção desta energia pode gerar a quebra ou a reorganização das cadeias químicas (VERTES, 2003).

\subsection{Acelerador de elétrons}

O acelerador de elétrons é um dispositivo que aplica forças a partículas carregadas por meio de uma combinação de campos elétricos e magnéticos, o que acaba gerando íons com velocidade e energia cinética altas. Quando se estabelece um potencial de alta tensão entre cátodo e o ânodo, no vácuo, o cátodo emite o feixe de elétrons conforme mostrado na FIG. 5 (SWALLOW, 1960; TABATA, 1981).

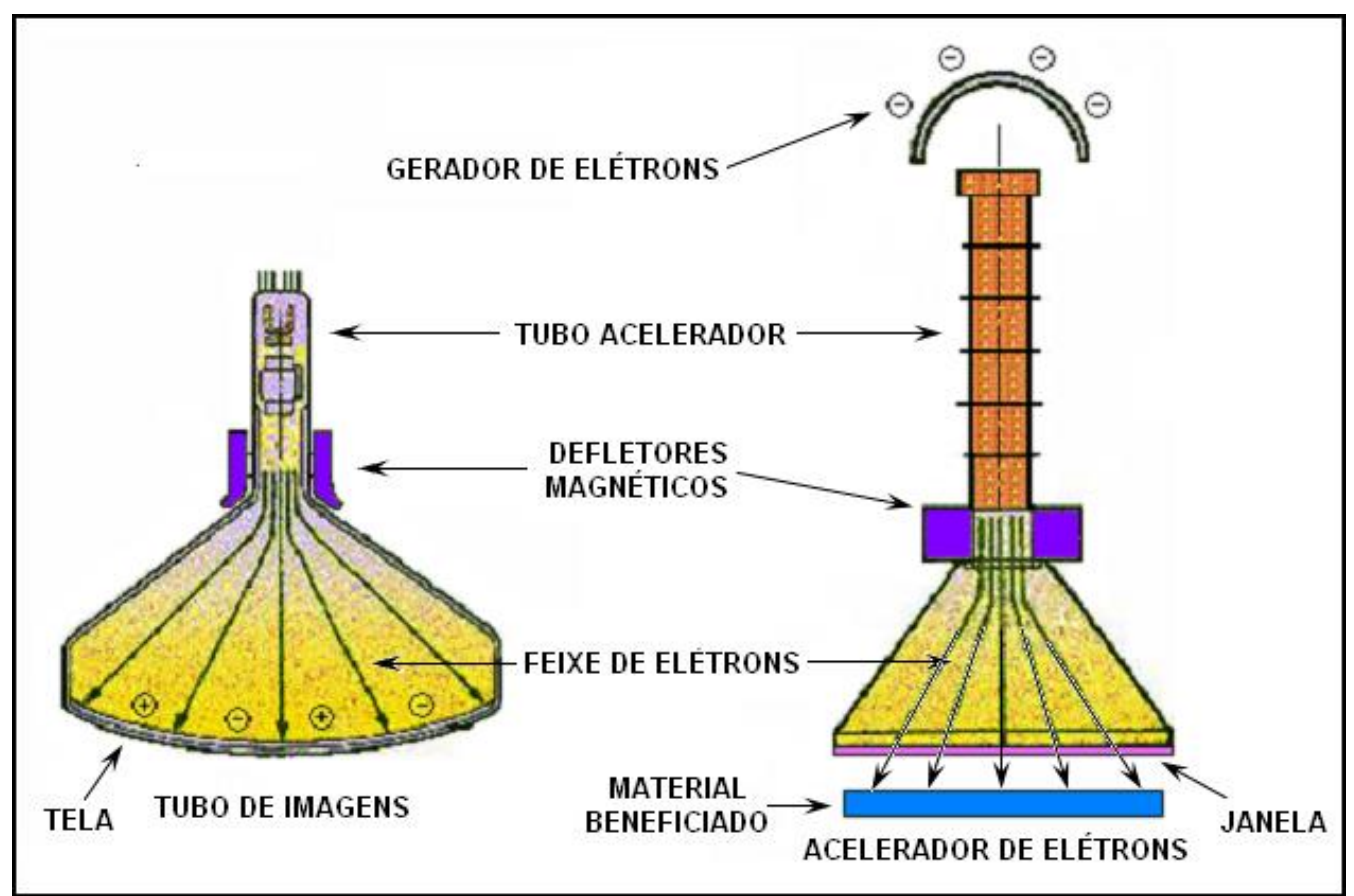

FIGURA 5 - Comparação de um tubo de imagens de um televisor com o acelerador de elétrons

Fonte: MOURA, 2006.

Os principais componentes e subsistemas de um acelerador de elétrons são a fonte de alta tensão, o tubo acelerador com seu sistema de vácuo, o canhão de elétrons, sistemas de radiofrequência, câmara de ionização, painel de controle e um sistema de segurança que inclui a blindagem da radiação (MEHNERT, 1995). Além de poder gerar elétrons acelerados, os aceleradores de elétrons também podem gerar partículas com poder de penetração diferentes, tais como os raios-X de energia alta que possuem moderado poder de penetração no material e partículas fotônicas com alto poder de penetração. Além 
disso, também facilita a criação e controle de diferentes atmosferas de irradiação (MIRANDA, 1999).

Os aceleradores de elétrons, nos últimos anos, têm sido de grande utilização na indústria de cura de resinas, tintas e vernizes, de reticulação de isolamento de cabos elétricos, espumas de polietileno, pré-vulcanização de componentes para pneus, na produção de tubos e embalagens termorretráteis para alimentos, materiais biomédicos, fitas adesivas, entre outros (MIRANDA, 1999).

Os aceleradores de elétrons para aplicações industriais podem ser divididos de acordo com a energia do feixe produzido em aceleradores de energia baixa e de energia alta (TABATA, 1981).

De modo geral os acelerados de corrente contínua são caracterizados pela alta potência de saída e alta eficiência, enquanto os sistemas "LINAC" são tipicamente muito mais compactos e pode gerar feixe de energia alta, porém são consideravelmente menos eficientes. Similarmente, as máquinas de ondas contínuas podem ser moderadamente compactas e podem alcançar energia alta de feixe (MIRANDA, 1999; SOUZA, 2009).

\subsection{Feixes de elétrons}

Os elétrons acelerados perdem energia por interações de Coulomb com os átomos ou moléculas presentes no material que está sendo irradiado. Com isso resulta na formação de radicais livres, íons, elétrons e átomos ou moléculas no estado excitado. Os elétrons gerados em aceleradores possuem energia auto-suficiente para romper qualquer tipo de ligação química e iniciar uma reação de polimerização. Porém, a penetração do elétron na matéria é função da sua energia (IAEA, 1992; YAMASAKI 1997). O feixe de elétrons ("eletron beam") é uma radiação ionizante gerada em máquinas industriais, denominadas de aceleradores de elétrons. Esses elétrons estão dentro de uma faixa de energia que vai de quilo eletronvolts $(\mathrm{keV})$ até milhões de eletronvolts $(\mathrm{MeV})$ que são absorvidos pela matéria e elétrons secundários sendo produzidos como resultado dos processos de interação.

A absorção de energia proveniente da radiação ionizante produzida por feixe de elétrons acelerados pelo meio absorvedor ocorre devido às interações da radiação com a nuvem eletrônica do meio. Os elétrons do feixe não possuem energia suficiente e não alcançam o núcleo, interagem somente com a eletrosfera não tornando o material radioativo. Assim sendo, o processo de irradiação com feixe de elétrons é interessante para irradiar materiais (ORTIZ, 2005). 


\subsection{Efeitos da radiação em polímeros}

A interação da radiação ionizante com a matéria promove eventos físicos, químicos e físico-químicos. Quando um determinado polímero ou filme polimérico é submetido à radiação ionizante pode sofrer várias modificações na sua estrutura física e química induzidas pela interação da radiação com o polímero (CLEGG, 1991; GOULAS, 2003).

Quando um polímero é submetido à irradiação ocorrem duas reações diferentes e simultâneas, a cisão das ligações da cadeia principal (degradação) e formação de ligações químicas entre moléculas poliméricas diferentes (reticulação). Tais reações são concorrentes e a predominância de uma sobre a outra depende das condições de processo e do próprio polímero, do tipo de radiação, presença de oxigênio, além de aditivos, grau de cristalinidade e homogeneidade do absorvedor, entre outras (MIRANDA, 1999; SOUZA, 2009).

Os radicais livres e demais espécies formadas podem ficar aprisionadas por algum tempo na matriz polimérica causando modificações denominadas efeitos pósirradiação (MIRANDA, 1999; SOUZA 2009). Os efeitos pós-irradiação podem ser explicados a partir da interação da radiação ionizante com compostos orgânicos que produz principalmente cátions, ânions, radicais livres e espécies excitadas, quando os polímeros são irradiados.

As mudanças causadas pela radiação ionizante nos polímeros podem modificar substancialmente as suas propriedades físico-químicas, mecânicas, térmicas, ópticas, entre outras.

\subsubsection{Reticulação}

O processo de reticulação ocorre pela recombinação entre radicais formando redes tridimensionais do polímero irradiado. $\mathrm{Na}$ ligação cruzada as cadeias poliméricas se conectam por meio de ligações covalentes geradas por reações químicas formando pontes de átomos.

Esta ponte pode ser, por exemplo, à base de enxofre (vulcanização) ou monômero bifuncional (cura de poliéster insaturado com estireno). A cura ou vulcanização também podem ser usadas para descrever os fenômenos de reticulação (CANEVAROLO JÚNIOR, 2002). 
No processo de reticulação, há um aumento da massa molar, da resistência mecânica, das redes tridimensionais do sistema, da viscosidade, alteração na temperatura de transição vítrea da fase amorfa e diminuição da solubilidade do polímero irradiado. Todo esse mecanismo também depende da dose de radiação, taxa de dose, o ambiente onde é realizada a irradiação: ar, oxigênio, nitrogênio, vácuo, temperatura, concentração, entre outros (LANDI, 2003, O’DONNELL \& SANGSTER, 1970, SOUZA, 2009).

A reticulação é a formação de ligações intermoleculares na cadeia polimérica, as moléculas poliméricas se ligam quimicamente, formando uma única molécula, de massa molar média maior. Deve-se levar em consideração a estrutura do polímero e as condições experimentais durante a irradiação, sensibilidade do polímero às mudanças de parâmetros, pois depende do tipo e do tamanho das cadeias como também da morfologia do polímero (O’DONNELL, SANGSTER, 1970). A reticulação de polímeros pode ser iniciada por radiação ionizante ou por iniciadores químicos (agentes de reticulação) como os peróxidos orgânicos, compostos à base de enxofre, amidas, aminas, silanos, entre outros (MIRANDA, 1999).

Do ponto de vista de materiais de embalagens, o processo de reticulação tem como objetivo conferir aos materiais determinadas propriedades, tais como: maior resistência química, maior resistência à degradação térmica, melhores propriedades adesivas, melhores propriedades de barreiras, maior estabilidade ao calor e menor fluência, entre outras (CLEGG, 1991; MIRANDA, 1999).

\subsubsection{Degradação}

A interação da radiação ionizante com a cadeia polimérica pode gerar um processo de cisão. Na cisão ocorre um rompimento aleatório das ligações químicas obtendo-se um polímero com menor massa molar. Há ainda a formação de gases e insaturação, com perda de suas propriedades mecânicas (FERRO, 2003).

A degradação pode ser definida como uma série de reações químicas que envolvem também ruptura das ligações da cadeia principal da macromolécula, também com redução da massa molar e consequentemente queda nas propriedades físicomecânicas, modificação química destrutiva, com a quebra de ligações covalentes e formação de novas ligações. Como exemplo pode-se citar: oxidação, hidrólise, cisão de cadeia, entre outras (MIRANDA, 1999; CANEVAROLO JÚNIOR, 2002). 
A degradação por radiação do polímero também pode ser favorecida pela presença de oxigênio em razão principalmente da formação de peróxidos, que impedem a recombinação dos radicais poliméricos no final da cadeia (MIRANDA, 1999).

\subsection{Reciclagem de borracha de pneus inservíveis}

A seguir são apresentados alguns trabalhos que foram realizados, utilizando-se diversos métodos de reciclagem, processamento e recuperação de materiais poliméricos, como a borracha e a borracha de pneus.

A reciclagem de borracha é um assunto bastante discutido, principalmente no caso de pneus. Existem relatórios com dados disponíveis sobre produção e consumo de borracha e comparativamente boa informação sobre a localização de pneus usados. Muito pouco se sabe do destino de outros itens de borracha. A incineração e disposição em aterros sanitários ainda são os principais métodos para a eliminação de pneus velhos e por sua vez, não são métodos ambientalmente adequados. Devem ser propostos métodos melhores e mais eficazes para a reciclagem e valorização de resíduos de borracha para fazer uso desse precioso recurso. Entre as inúmeras propostas algumas seguem uma rota tecnologicamente avançada (MENNING, 1998).

A quantidade de pneus inservíveis tem aumentado a cada ano e uma das alternativas para diminuir esse resíduo é seu uso na modificação de ligantes asfálticos. Do ponto de vista ambiental e econômico, o uso de borracha de pneu em pavimentação tem se mostrado como uma solução potencial para resolver esse problema da disposição inadequada de pneus (LIMA, 2008; NAVARRO et al., 2002). Muitas são as vantagens previstas em função de incorporação de borracha de pneu ao ligante asfáltico sendo que algumas merecem destaque como: redução no envelhecimento, aumento na flexibilidade das misturas asfálticas, aumento no ponto de amolecimento e redução na susceptibilidade térmica (LIMA, 2008; NAVARRO et al., 2002). No Brasil existem vários estudos com desenvolvimento do ligante asfáltico e borracha (LIMA, 2008; BERTOLLO, JÚNIOR, SCHALCH, 2002; MARTINS, 2004), mas os dados apresentados, na sua maioria, são basicamente realizados por meio de ensaios. Considerações sobre as propriedades reológicas, química do ligante asfáltico, envelhecimento oxidativo, interação química com os agregados e um aditivo ideal para melhorar a viscosidade ainda são necessárias (LIMA, 2008; AKISETTY, LEE, AMIRKHANIAN, 2007).

A utilização de pneu moído, ou pó de pneu como modificador do ligante asfáltico, tem-se mostrado uma alternativa ambientalmente adequada que pode promover 
reduções de volume desse resíduo. Há que se considerar ainda o aspecto mais importante, que é a redução de custos de manutenção com a menor degradação do pavimento asfáltico em serviço (NAVARRO et al., 2004). No Arizona esta experiência mostrou uma diminuição na susceptibilidade térmica e um aumento de ductibilidade, resiliência e ponto de amolecimento do ligante, acarretando pavimentos mais duráveis e de melhor qualidade (LIMA, 2008; CHOUBANE, et al., 1999). Também foi mostrado no referido estudo que misturas com ligante asfáltico de borracha resistiam à propagação de trincas oriundas de outras camadas.

O desenvolvimento de equipamentos para pesquisa em química aplicada para o processamento de uma variedade grande de materiais, incluindo: borrachas, polímeros, compostos, minerais, solos, rejeitos, pós de diversos produtos, como por exemplo, pó de borracha e produtos químicos, era constituído de um sistema de injeção de microondas acoplado ao tubo guia de ondas. Outro equipamento era formado por um sistema de irradiação combinando feixe de elétrons (EB - "electron beam") com microondas, esses equipamentos mostraram alternativas benéficas no processamento destes materiais, comparadas com o processo convencional usando aquecimento (MARTIN, 2010).

A vulcanização trata-se do processo químico de conversão da borracha por meio de ligações cruzadas. A borracha sai de um estado essencialmente plástico para um estado elástico. Esse processo modifica as propriedades da borracha e confere a ela três características: eliminação da plasticidade, da termoplasticidade e introdução da insolubilidade (VIEIRA, 2009; PINHEIRO, 2001). O processo de desvulcanização baseiase no processo de quebra de ligações cruzadas geradas durante a vulcanização, não é a reversão do processo de vulcanização, o material resultante é diferente tanto da borracha virgem quanto da vulcanizada (VIEIRA, 2009).

Em uma pesquisa, a desvulcanização por microondas foi realizada por fornos microondas domésticos adaptados (com hastes de agitação que giram com a velocidade controlada levando a uma incidência homogênea das microondas sobre a amostra). $\mathrm{O}$ tratamento por microondas tem forte influência sobre as propriedades dinâmico mecânicas da borracha, inclusive em relação à posição dos picos referentes às transições térmicas do material. Também foi observado na análise dinâmico-mecânico de borrachas de pneus desvulcanizadas por microondas com diferenças de tempo de tratamento que, apesar delas ser uma mistura de mais de um tipo de elastômero, somente foi possível discernir uma transição térmica, com exceção do material tratado por 4 minutos (VIEIRA, 2009; SCURACCHIO, WAIKI, 2005). 
A mudança na propriedade do material pelo tempo de exposição ás microondas é maior que o tempo que o material fica exposto as microondas. Mudanças estruturais significativas são provocadas nos polímeros constituintes de borracha de pneu pela desvulcanização por microondas, essas mudanças são suficientes para alterar a $T_{g}$ do material (VIEIRA, 2009; SCURACCHIO, WAIKI, 2005). Os elastômeros utilizados em pneus são misturas físicas de polímeros apolares: borracha natural (NR) e do copolímero de butadieno e estireno (SBR) ou NR e polibutadieno (BR) apresentando quase nenhuma interação com as microondas. Mas esta dificuldade é contornada pela utilização de cargas condutoras de eletricidade, como negro de fumo que promove um fenômeno chamado de polarização de Maxwell-Wagner, o que permite o aquecimento da borracha de pneu (VIEIRA, 2009; SCURACCHIO, WAIKI, BRETAS, 2006). A polarização de MaxwellWagner (interfacial) surge nas descontinuidades de fases, materiais diferentes, vazios e impurezas, ocorrendo à formação de cargas espaciais nas interfaces destas regiões devido às diferenças de condutividade e permissividades (VIEIRA, 2009).

Foram relatados que grãos de borracha em pó e resíduos desvulcanizados de borracha, passados por uma rosca contínua de cisalhamento foram usados como reforços para borracha natural virgem. Os resultados obtidos pelo método de fração gel provaram que houve cisão da cadeia principal. Foram estudadas as características de cura, intumescimento ("swelling", inchaço) e densidade das ligações cruzadas e propriedades mecânicas. Essas amostras constituídas de pneus de automóveis de passageiros e de caminhões leves apresentaram propriedades mecânicas aplicáveis nos novos compostos de borracha. Os compostos de borracha desvulcanizados demonstraram ter melhor propriedades do que aqueles que continham grãos de borracha em pó (LI, LAMMINMAKI, HANHI, 2005).

Foi desenvolvido um processo, no qual pedaços de borracha vulcanizada provenientes de pneus descartados e restos industriais foram desvulcanizados misturando os aos pedaços de borracha preparados com o novo agente de regeneração dentro de uma extrusora de rosca dupla. Essa combinação do agente de regeneração e ação da extrusora que permite controlar pressão e temperatura, tempo de interrupção e tensão de cisalhamento promove o rompimento das ligações cruzadas do enxofre nos pedaços de borracha sem quebrar a cadeia principal do polímero. Esse processo transforma os refugos de borracha vulcanizada em material elastomérico reutilizável, mantendo muitas propriedades do elastômero original nos compostos similares. Este processo começa pela preparação dos refugos de borrachas para recuperação. Se os refugos são provenientes de 
pneus moídos então os reforços de metais e de fibras devem ser removidos, caso haja algum. Exemplos de sucatas de borrachas vulcanizadas, que são possíveis de serem utilizadas neste processo, incluem a borracha natural (NR), borracha de copolímero de estireno e butadieno (SBR), borracha de policloropreno (CR), borracha nitrilica (NBR) e borracha etileno-propeno-dieno (EPDM).

Os restos de borracha originados de outros tipos de borracha vulcanizada com enxofre foram moídos até se tornar um pó fino, usando técnicas convencionais de trituração e moagem, que podem incluir técnicas criogênicas. Para se obter uma mistura homogênea, restos de borracha são moídos até um tamanho de partícula com limite aproximado de no mínimo 20 mesh, mas é preferível que seja entre 40 mesh e 60 mesh ou até mais fino, em razão do fato de quanto mais fino o pó da borracha melhor é a homogeneidade, com isso se obtêm melhora nas propriedades físicas como, por exemplo, alongamento na ruptura e resistência à tração de um produto final revulcanizado. Restos de borracha podem ser fragmentados e moídos na temperatura ambiente, e preferencialmente devem ser primeiramente congelados criogenicamente e então moídos, para facilitar a moagem até pedaços mais finos resultando em melhores características de fluxo (TANG, 2003).

Foi estudada a reciclagem realizada por irradiação de raios gama em câmara de ar de pneus confeccionada com borracha butílica. Foram estudados os efeitos da radiação gama nestas câmaras de ar usadas. Os pedaços de borracha butílica desvulcanizada por métodos convencionais foram substituídos em pedaços de $15 \mathrm{phr}$ (partes por 100 partes de borracha, "per hundred of rubber") na formulação dos compostos. Também, foram estudadas as propriedades reológicas e mecânicas e o grau de dispersão de negro de fumo para os dois tipos de compostos. Em seguida, foram comparados aos de compostos de borracha butílica virgem. A migalha de borracha virgem deteriora as propriedades mecânicas quando adicionada ao composto. Essa deterioração das propriedades mecânicas dos compostos preparados por meio de reciclagem de câmeras de ar irradiadas em seu interior com doses de radiação ionizante de $120 \mathrm{kGy}$ é muito menor do que os compostos preparados usando migalhas de borracha butílica. Foi observado que as propriedades das câmaras de ar irradiadas com radiação gama eram compatíveis com as da borracha butílica comercial e que poderiam ser recicladas e adicionadas nos compostos de borracha butílica (KARAAGAÇ et al., 2007).

Foram estudados na literatura processos de irradiação para modificação de materiais aplicados em cadeias tecnológicas que podem ter vantagens significativas 
principalmente em termos econômicos e ecológicos, se comparado aos métodos químicos, térmicos e mecânicos. Em relação às borrachas butílicas utilizadas nas indústrias de pneus sabe-se que elas contaminam o meio ambiente por um longo período. Foram realizados experimentos e divulgados em literatura sobre a aplicação de feixe de elétrons com energia de 6 a $10 \mathrm{MeV}$ para degradar a borracha butílica usada. A radiodegradação do material foi testada para reutilização em formulação inicial e para a mistura obtida para aplicação em tecido de coberturas (TELNOV, 2002).

\subsection{Análise térmica}

A análise térmica pode ser definida como um grupo de técnicas por meio das quais uma propriedade física de uma substância e/ou de seus produtos de reação é medida em função da temperatura, enquanto essa substância é submetida a uma programação controlada de temperatura (GIOLITO, IONASHIRO, 1980; AMERICAN SOCIETY FOR AND MATERIAL STANDARDS (ASTM) E473-08, 2008).

Na TAB. 3 estão listadas as principais técnicas termoanalíticas em função da propriedade física medida e a abreviatura aceitável.

TABELA 3 - Propriedades físicas medidas em análise térmica, técnica derivada e abreviatura recomendada pela ICTAC (GIOLITO, IONASHIRO, 1988)

\begin{tabular}{|c|c|c|}
\hline Propriedade física & Técnica derivada & Abreviatura \\
\hline Massa & $\begin{array}{c}\text { Termogravimetria } \\
\text { Detecção de gás desprendido } \\
\text { Análise de gás desprendido } \\
\text { Análise térmica por emanação }\end{array}$ & $\begin{array}{l}\text { TG } \\
\text { EGC } \\
\text { EGA } \\
\text { ETA }\end{array}$ \\
\hline Temperatura & $\begin{array}{l}\text { Determinação da curva de aquecimento }(*) \\
\text { Análise térmica diferencial }\end{array}$ & DTA \\
\hline Entalpia & Calorimetria exploratória diferencial $(* *)$ & DSC \\
\hline Dimensões & Termodilatometria & TD \\
\hline Características mecânicas & $\begin{array}{c}\text { Análise termomecânica } \\
\text { Análise termomecânica dinâmica }\end{array}$ & $\begin{array}{l}\text { TMA } \\
\text { DMA }\end{array}$ \\
\hline Características acústicas & $\begin{array}{c}\text { Termossonimetria } \\
\text { Termoacustimetria }\end{array}$ & $\mathrm{TS}$ \\
\hline Características ópticas & Termoptometria & TO \\
\hline Emissão de luz & Termoluminescência & TL \\
\hline Características elétricas & Termoeletrometria & TE \\
\hline Características magnéticas & Termomagnetometria & TM \\
\hline
\end{tabular}

Fonte: CANEVAROLO JÚNIOR, 2003. 
Um analisador térmico é basicamente composto por um forno, no qual a amostra é aquecida/resfriada a uma taxa controlada e sob atmosfera previamente estabelecida, um transdutor, que converte as propriedades físicas em sinais elétricos, um amplificador e uma unidade controladora interfaceada a um microcomputador.

\subsubsection{Termogravimetria (TG) e Termogravimetria Derivada (DTG)}

A termogravimetria é uma técnica termoanalítica na qual a variação de massa (perda ou ganho) é medida em função da temperatura e/ou tempo, enquanto a amostra é submetida a uma programação controlada de temperatura (GIOLITO, IONASHIRO, 1980; ASTM E473-08, 2008). A amostra pode ser aquecida ou resfriada, a uma velocidade selecionada, ou pode ser mantida a uma temperatura fixa.

O equipamento de análise termogravimétrica é composto principalmente por um forno e uma microbalança (termobalança), um programador de temperatura e um sistema de aquisição de dados (microcomputador). O equipamento permite trabalhar sob as diferentes condições experimentais: diversas atmosferas gasosas e massas de amostras, diferentes razões de aquecimento e/ou condições isotérmicas em temperaturas específicas, entre outras.

Tal diversificação de condições experimentais permite realizar vários tipos de estudos:

a) avaliação da estabilidade térmica de materiais diversos;

b) avaliação da estabilidade de compostos intermediários e do produto final;

c) determinação de composição;

d) obtenção de parâmetros cinéticos de reações de decomposição térmica;

e) elucidação de fenômenos ocorridos em virtude de processos físicos e químicos, como desidratação, vaporização, dessorção, oxidação, redução, entre outros;

f) determinação da pureza de amostras.

Muitas vezes, certas reações que ocorrem em uma mesma faixa de temperatura ocasionam curvas TG que consistem em uma única perda de massa contínua. Contudo, quando se utiliza o recurso da curva derivada primeira da termogravimetria (DTG), variações de massa sutis são ressaltadas em razão das inflexões originadas nestas curvas (WENDLANT, 1985).

Quando não há variação de massa, dm/dt ou dm/dT é zero; contudo, quando ocorre variação de massa, o ponto de inflexão na curva TG se torna um máximo na curva DTG. A área da curva DTG é correspondente à perda de massa e a altura do pico fornece a 
razão de variação de massa em determinada temperatura (HATAKEYAMA, QUINN, 1999).

A curva DTG pode ser obtida por métodos de diferenciação manual da curva TG ou por diferenciação eletrônica do sinal de TG. Ela é puramente uma forma diferente de apresentação dos dados, porém na maioria dos casos a sua utilização é essencial para interpretação da curva TG. Sendo assim, é possível obter as seguintes informações por meio da curva DTG (MATOS, 2012):

a) Diferenciação de eventos térmicos sobrepostos ou com pequenas variações de massa;

b) Determinação da temperatura em que a taxa de variação de massa é máxima $\left(\mathrm{T}_{\text {pico }}\right)$;

c) Auxílio na determinação de $T_{\text {onset }}$ e $T_{\text {endset }}$ (início e final extrapolado do evento térmico, respectivamente) e $\mathrm{T}_{\text {inicial }}$ e $\mathrm{T}_{\text {final }}$ dos eventos térmicos;

d) Determinação de informações cinéticas por meio de cálculo da altura do pico.

Como em toda técnica instrumental, há alguns fatores que afetam a natureza, precisão e exatidão dos resultados experimentais. Dentre os principais estão os fatores instrumentais e os relacionados às características da amostra (CANEVAROLO JÚNIOR, 2003; LUCAS, SOARES, MONTEIRO, 2001; HATEKEYAMA, QUINN, 1999).

Em virtude do grande número de fatores que podem determinar os resultados experimentais é importante que essas variações sejam minimizadas, de forma a fixar o maior número possível de condições de ensaio quando existir o objetivo de comparar materiais. Por isso, é primordial que as curvas TG/DTG venham sempre acompanhadas de informações referentes às condições de ensaio utilizadas (MATOS, 2012).

\subsubsection{Calorimetria exploratória diferencial (DSC)}

DSC é a técnica pela qual se mede a diferença de energia fornecida à substância e a um material de referência, termicamente inerte, em função da temperatura, enquanto a substância e a referência são submetidas a uma programação controlada de temperatura. Essa técnica é derivada da DTA, por isso, são consideradas técnicas semelhantes e complementares, pois, permitem avaliar as variações entálpicas que ocorrem com uma dada substância durante um processo de aquecimento ou resfriamento. A palavra "diferencial" enfatiza as medidas que envolvem tanto a própria substância como o material de referência, que deve ser termicamente estável. A definição formal destas duas técnicas 
foi aprovada pela União Internacional de Química Pura e Aplicada (IUPAC) (CANEVAROLO JÚNIOR, 2003).

A DSC, pelo seu próprio refinamento, possibilita acompanhar e obter dados quantitativos quanto às alterações físicas ou químicas da amostra, tais como: mudança de estado físico (fusão, ebulição, etc), transições de fase (modificações na estrutura cristalina) ou reações de desidratação, de decomposição, de oxi-redução, etc (MATOS, 2012).

Historicamente, foram criados dois tipos de DSC:

a) DSC de compensação de potência (desenvolvido e patenteado pela PerkinElmer Corporation);

b) DSC fluxo de calor (desenvolvido por outras empresas, como por exemplo a Mettler Toledo, Shimadzu Corporation, Netzsch, TA Instrument, Setaram, Seiko, Linses, Rigaku e outras).

Na DSC de compensação de potência a amostra e a referência são aquecidas em compartimentos separados, individualmente. Isto torna possível manter a amostra e a referência em condições isotérmicas, ao contrário da técnica DTA. Assim, se a amostra sofre alterações de temperatura em razão de um evento endotérmico ou exotérmico em função do aquecimento ou resfriamento a que é submetida ocorre uma modificação na potência de entrada do forno correspondente, de modo a se anular essa diferença. Isso consiste no "balanço nulo" de temperatura (MATOS, 2012).

$\mathrm{Na}$ DSC com fluxo de calor, a amostra e a referência são colocados em cápsulas idênticas, localizadas sobre um disco termoelétrico (sensor de resistência térmica) e aquecidos por uma única fonte de calor. O desempenho da DSC com fluxo de calor é semelhante ao com compensação de potência, porém esta técnica foi desenvolvida a partir da DTA, para contornar a patente registrada pela Perkin-Elmer que desenvolveu o DSC com compensação de potência (MATOS, 2012).

No sistema DSC o calor é transferido por meio do disco termoelétrico para a amostra e a referência, e o fluxo de calor diferencial $(\Delta \mathrm{T})$ entre os dois é controlado por termopares conectados abaixo dos cadinhos. Dessa forma, a diferença no fluxo de calor da amostra e da referência é diretamente proporcional à diferença de potência das junções dos dois termopares. Outra diferença importante entre os sistemas DSC, em relação ao sistema DTA, é sobre a apresentação de resultados, pois na DSC com compensação de potência foi adotada a convenção termodinâmica, onde um evento endotérmico $(\Delta \mathrm{H}>0)$ é caracterizado por um pico ascendente na curva DSC, enquanto na DSC com fluxo de calor esse mesmo evento é representado na curva DSC por um pico descendente. Além disso, na DSC com 
fluxo de calor o sinal é originado da diferença da temperatura entre a amostra e a referência; entretanto, na DSC com compensação de potência o sinal é proveniente do calor diferencial fornecido pela amostra e referência (MATOS, 2012).

Pode ser medida na DSC a diferença na taxa de fluxo de calor entre a amostra e referência (cadinho vazio) enquanto ambos são aquecidos, resfriados ou mantidos isotermicamente.

As diferenças no fluxo de calor ocorrem em razão:

a) do aumento da capacidade de calor da amostra com a temperatura;

b) das transições que ocorrem na amostra.

A taxa de fluxo de calor pode ser expressa em uma variedade de unidades que também podem ser normalizadas para a massa usada da amostra:

- $\mathrm{mW}$ sendo $\mathrm{W}=\mathrm{J} / \mathrm{s}$

- $\mathrm{W} / \mathrm{g}$

- $\mathrm{mCal} / \mathrm{s}$

- BTU/h

Transições exotérmicas resultam em liberação de calor: cristalização, cura, decomposição, entre outras.

Transições endotérmicas absorvem calor: fusão, transição vítrea, evaporação, entre outras (MATOS, 2012).

O princípio do equipamento utilizado neste estudo foi o de fluxo de calor.

\subsection{Ensaios mecânicos}

\subsubsection{Resistência à tração, flexão e compressão}

\subsubsection{Princípios Fundamentais}

As propriedades mecânicas dos materiais poliméricos são de grande importância e interesse científico e tecnológico, em função dos requisitos e/ou exigências que os diversos polímeros encontrados devem atender na maior parte de suas aplicações. Valores de propriedades mecânicas, por exemplo, a resistência à tensão, módulo de elasticidade, elongação, entre outras, podem servir como base de comparação do desempenho mecânico dos diferentes polímeros, bem como para a avaliação dos efeitos decorrentes da modificação do polímero base (reforços, cargas, aditivos, plastificantes). $\mathrm{Na}$ prática, a análise das propriedades mecânicas destes materiais é uma das considerações 
primordiais a serem feitas no processo de seleção dos materiais poliméricos para o projeto de uma peça ou de um produto. Estes valores de propriedades mecânicas são obtidos por meio de ensaios mecânicos padronizados, entre os quais se destacam os ensaios de solicitação mecânica sob tração, flexão e compressão (CANEVAROLO JÚNIOR, 2003).

Geralmente os valores das propriedades mecânicas dos polímeros comerciais são, geralmente, encontrados nos catálogos do fabricante do material. No caso de novas formulações desenvolvidas em centros de pesquisa, tais valores podem ser obtidos em literaturas especializadas, como dissertações e teses, em comunicações extraídas de congressos e reuniões científicas, ou em artigos científicos de periódicos especializados (CANEVAROLO JÚNIOR, 2003).

\subsubsection{Curva tensão versus deformação.}

Os resultados dos ensaios de resistência mecânica sob tração, flexão e compressão são observados como curvas do tipo tensão versus deformação. Os ensaios são realizados por meio da aplicação de uma solicitação ao material mediante condições controladas, normalmente deformação a velocidade constante, até a ruptura do material ou até que a tensão ou deformação atinja um valor pré-estabelecido. Durante o experimento, a carga ou tensão suportada pelo material (resposta do material) e a deformação a ele imposta são registrados. Exemplificando, nos ensaios de resistência à tração, a solicitação é realizada por meio de uma deformação sob tração e a resposta alcançada é uma tensão de tração. Analogamente, para os ensaios de flexão são alcançadas curvas do tipo tensão sob flexão e deformação sob flexão, e nos ensaios de compressão as curvas são de tensão sob compressão e deformação sob compressão (CANEVAROLO JÚNIOR, 2003).

Para as amostras de pneus inservíveis de automóvel foi usado o método de tração.

\subsubsection{Resistência mecânica dos polímeros}

Em comparação aos metais e cerâmicas, os polímeros exibem resistência mecânica bastante inferior. Isto ocorre essencialmente em razão das diferenças na estrutura e nas ligações atômicas e moleculares apresentadas por estes materiais. Polímeros constituem ligações primárias covalentes entre os átomos da cadeia principal e ligações secundárias fracas com baixa energia de ligação entre as cadeias poliméricas, por exemplo, forças de Van der Waals, interações entre dipolos, ligações de hidrogênio, entre outras. 
Diferentemente, nos metais e nas cerâmicas os átomos e moléculas estão completamente unidos por ligações primárias fortes, como por exemplo, a ligação metálica para os metais e as ligações iônica e covalente para as cerâmicas. Essa diferenciação na estrutura dos polímeros na comparação com os metais e as cerâmicas, em termos de energias de ligação, é a grande responsável pelo comportamento mecânico inferior dos polímeros quando relacionados com outros materiais (CANEVAROLO JÚNIOR, 2003).

\subsubsection{Comportamento dos polímeros em ensaios mecânicos}

A estrutura molecular do polímero é responsável pelo seu comportamento mecânico. Em conformidade com este comportamento, os materiais poliméricos podem classificar-se em termos de rigidez, fragilidade e tenacidade. $\mathrm{O}$ aspecto de um diagrama tensão versus deformação é onde se baseia tal classificação. Sendo que se pode observar por meio das curvas de tensão versus deformação sob tração, comportamentos típicos de alguns materiais poliméricos, obedecendo a classificação a seguir.

Os cinco comportamentos típicos de polímeros em ensaios de tração são:

(a) Polímeros com elevado módulo de elasticidade e baixa elongação na ruptura. Este material pode ou não escoar antes de sua ruptura. Dentro desta característica pode-se citar a resina fenólica;

(b) Polímeros com elevado módulo de elasticidade, tensão de escoamento e tensão de ruptura e moderada elongação na ruptura. Os poliacetais são um bom exemplo desta classe de polímero;

(c) Polímeros com elevado módulo elástico, tensão no escoamento, elongação na ruptura e resistência máxima a tração. O policarbonato é avaliado como um polímero duro e tenaz se caracterizando como exemplo desta categoria;

(d) Polímeros com baixo módulo de elasticidade, baixa tensão de escoamento, porém elevadas elongação e tensão no ponto de ruptura. O polietileno é um polímero desta categoria;

(e) Polímeros com baixos módulo de elasticidade e tensão no escoamento, e uma elongação no ponto de ruptura de moderada a elevada. O politetrafluoretileno (PTFE), conhecido pelo nome comercial Teflon ${ }^{\circledR}$, é um exemplo desta categoria.

Os elastômeros apresentam um comportamento atípico. Eles apresentam uma região elástica muito extensa. Além disso, esta região elástica é totalmente linear, ao contrário da maioria dos sólidos. Estes três tipos de comportamentos são mostrados na FIG. 6. A curva A é típica de uma resina termorrígida, a curva B é típica de um 
termoplástico parcialmente cristalino e a curva C é típica de um elastômero. Além dos diferentes níveis de alongamento, devem-se observar os diferentes níveis de resistência dos três materiais (CANEVAROLO JÚNIOR, 2003).

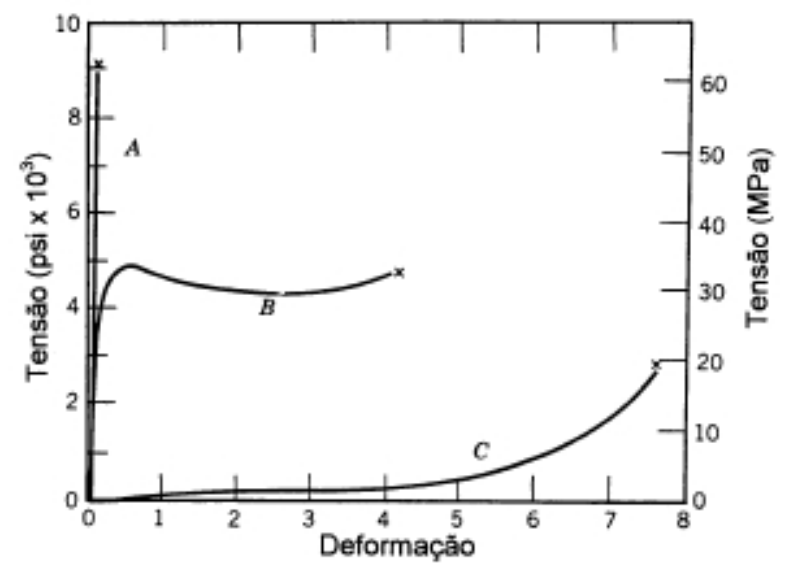

FIGURA 6 - Curvas tensão versus deformação obtidas no ensaio de tração de diferentes tipos de polímeros. $O$ comportamento frágil (A), comportamento dúctil (B) e comportamento elástico $(\mathrm{C})$ Fonte: (PADILHA, 2000; CALLISTER JÚNIOR, 1994).

Na FIG. 7 é mostrado o acentuado efeito da temperatura no comportamento mecânico de um elastômero. Observa-se que a temperatua de transição vítrea $\left(\mathrm{T}_{\mathrm{g}}\right)$ define a faixa de uso deste tipo de material, pois abaixo de $\mathrm{T}_{\mathrm{g}}$ o elastômero é duro e frágil. As temperaturas $\mathrm{T}_{\mathrm{g}}$ dos elastômeros estão bem abaixo da temperarura ambiente.

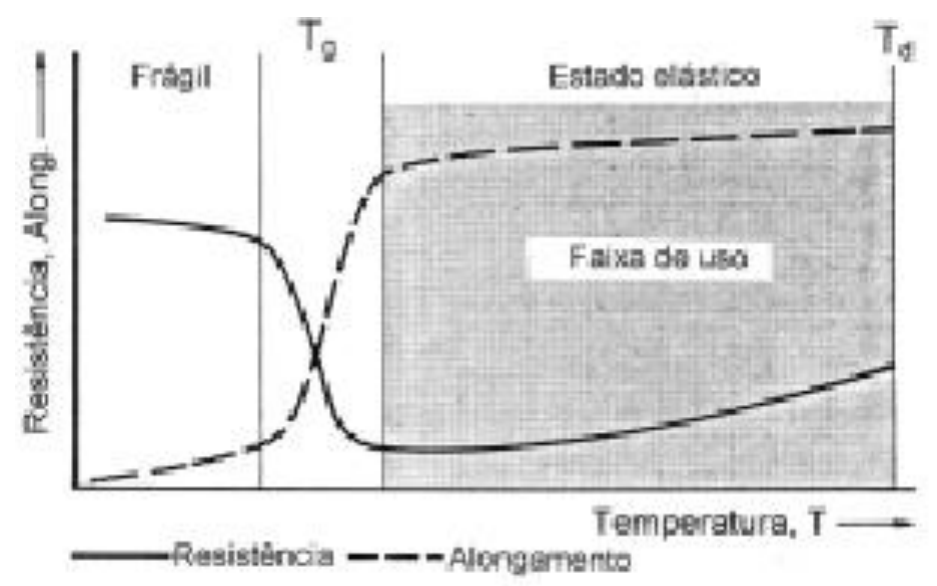

FIGURA 7- Efeito da temperatura no comportamento mecânico de um elastômero Fonte: (PADILHA, 2000; CALLISTER JÚNIOR, 1994). 


\subsubsection{Comportamento deformacional de polímeros}

O comportamento deformacional dos polímeros é impulsionado pela sua estrutura molecular. Este comportamento de polímeros é muito complexo, por envolver diversos fenômenos interligados a diferentes mecanismos moleculares. Na sequência, são descritos os principais fenômenos e os mecanismos associados que podem ocorrer em polímeros (CANEVAROLO JÚNIOR, 2003):

(a) Fluxo viscoso: onde a deformação do polímero é irreversível e está relacionada a movimentos de deslizamentos das cadeias poliméricas;

(b) Elasticidade da borracha: onde a liberdade local do movimento relacionado com movimentos de segmentos de cadeias poliméricas em pequena escala é limitada. Movimentos de escala maior, como o fluxo viscoso, são impedidos por uma estrutura de rede difusa. Neste fenômeno observado existe pouca deformação permanente;

(c) Viscoelasticidade: onde a deformação do polímero é parcialmente reversível, porém dependente do tempo. Está relacionada com a distorção das cadeias poliméricas em relação às suas conformações de equilíbrio, por meio de movimentos de segmentos da cadeia molecular do polímero envolvendo as ligações primárias da cadeia;

(d) Elasticidade Hookeana: onde os movimentos dos segmentos de cadeia são limitados e envolvem apenas estiramentos e deformações angulares das ligações primárias das cadeias do polímero (CANEVAROLO JÚNIOR, 2003).

\subsubsection{Testes padronizados para os ensaios mecânicos sob tração, flexão e compressão}

Propriedades mecânicas sob tração, flexão e compressão são definidas por testes padronizados e são especialmente úteis para propósitos de controle de qualidade e especificações.

Os princípios essenciais destes ensaios mecânicos estão citados de forma detalhada em normas técnicas especializadas (CANEVAROLO JÚNIOR, 2003).

As normas ASTM e ISO devem ser consideradas, pois estas metodologias de testes enfocam as características das propriedades mecânicas de plásticos reforçados e não reforçados, rígidos e semi-rígidos (CANEVAROLO JÚNIOR, 2003).

Estes ensaios usam como corpos de prova com geometrias, dimensões e tolerâncias dimensionais regulamentadas em cada norma técnica, mas, dentro de uma 
mesma norma, elas podem se caracterizar de forma diferente de acordo com o comportamento mecânico do polímero a ser ensaiado. Os corpos de prova podem ser preparados a partir de moldagem por injeção, ou ainda extraídos de chapas extrudadas, placas moldadas por compressão, laminados, tubos, peças acabadas ou semi-acabadas, entre outras modalidades. Uma quantidade mínima de cinco corpos de prova é exigida para um ensaio mecânico do tipo tração, flexão ou compressão. Para corpos de prova preparados a partir de moldagem por injeção, há normas técnicas que se referem ao procedimento de preparação (CANEVAROLO JÚNIOR, 2003).

As propriedades mecânicas dos polímeros objetivadas por estes ensaios podem variar com as condições de preparação dos corpos de prova, condições de armazenagem e testes dos corpos de prova. Para comparação de resultados, estes fatores devem ser rigorosamente controlados, e também minuciosamente mencionados junto de cada conjunto de resultados (CANEVAROLO JÚNIOR, 2003).

Quanto às condições de preparação, os corpos de prova devem ser preparados da forma mais homogênea possível. No caso de peças como chapas com elevada orientação molecular, os corpos de prova para cada conjunto de ensaios devem ser extraídos de uma mesma posição e direção.

Quanto às condições ambientais de acondicionamento e teste, as normas ISO, específicas para os ensaios de tração, flexão e compressão não possuem um critério próprio de armazenagem e teste de corpos de prova, e aconselham que sejam consultadas normas técnicas específicas. Diferentemente, as normas ASTM exibem especificação para as condições de armazenagem dos corpos de prova, que são: temperatura de $23 \pm 2^{\circ} \mathrm{C}$ e umidade de $50 \pm 5 \%$ por pelo menos 40 horas antes do teste. Os testes terão que ser realizados nas mesmas condições de temperatura e umidade (CANEVAROLO JÚNIOR, 2003).

Os ensaios realizados nos corpos de prova com a incorporação do pó de borracha de pneus inservíveis de automóvel foram realizados respeitando todas as condições descritas nas normas.

\subsubsection{Acessórios da Máquina Universal de Ensaios}

As garras para os ensaios de tração podem ter acionamento manual ou pneumático e devem ser utilizadas de acordo com o tipo de material a ser ensaiado. Materiais menos rígidos, como as borrachas, são ensaiados com garras de acionamento pneumático, ou ainda com garras que tenham mecanismo de auto ajuste da pressão 
exercida sobre o corpo de prova. Nos ensaios de filmes são também aplicadas garras com controle de pressão, porém elas são um pouco diferenciadas das utilizadas nos ensaios de elastômeros (CANEVAROLO JÚNIOR, 2003).

\subsubsection{Corpos de prova.}

Os corpos de prova para os ensaios de resistência à tração são produzidos na forma de halteres com a superfície da seção transversal plana. As dimensões dos corpos de prova devem ser definidas de acordo com o comportamento mecânico do polímero (rígido ou semi-rígido) a ser ensaiado. Na FIG. 8 é mostrada uma geometria típica de um corpo de prova para ensaios de tração. Suas dimensões essenciais são destacadas (CANEVAROLO JÚNIOR, 2003).

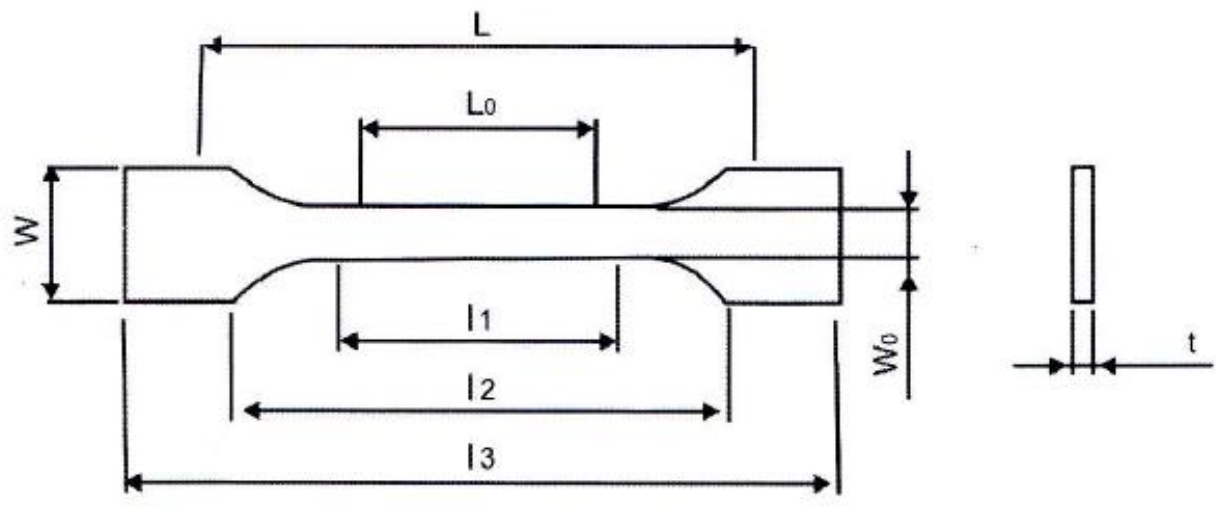

FIGURA 8 - Geometria e dimensões típicas de corpos de prova para ensaios de tração em polímeros

Nesta FIG. 8 os parâmetros em evidência são: $1_{3}$ é o comprimento total do corpo de prova, W é a sua largura total, $1_{2}$ é a distância entre as seções com superfícies paralelas de largura maior, $1_{1}$ é o comprimento da seção com superfícies paralelas de largura menor $\left(\mathrm{W}_{\mathrm{o}}\right)$, t é a espessura, $\mathrm{L}$ é a distância entre garras e $\mathrm{L}_{0}$ é o comprimento da seção estreitada. As medidas dos corpos de prova podem alternar de acordo com o comportamento do material a ser ensaiado.

\subsubsection{Velocidade do ensaio}

A velocidade do ensaio caracteriza a taxa de deformação que será utilizada ao polímero. A velocidade pode ser definida dentro de um intervalo de valores fornecidos pelas normas técnicas, de acordo com o comportamento mecânico do polímero (rígido ou 
semi-rígido) e da geometria do corpo de prova a ser ensaiado. A norma ASTM D638 aconselha que, se a velocidade de ensaio para um determinado polímero não estiver especificada, deve aplicar uma velocidade de maneira que o corpo de prova rompa dentro de um intervalo de tempo de meio a cinco minutos de teste (CANEVAROLO JÚNIOR, 2002; CANEVAROLO JÚNIOR, 2003).

Esses grupos de técnicas usadas para caracterização das propriedades mecânicas estão subdivididos entre: Ensaios com solicitação sobre impacto e ensaios com registro de curvas tensão - deformação (CANEVAROLO JÚNIOR, 2002).

Existem vários tipos de ensaios mecânicos para caracterizar os polímeros, eles podem ser estatísticos, dinâmicos, destrutivos, não destrutivos, de curta duração, de longa duração, entre outros. Essas solicitações podem ocorrer de forma tensão ou deformação, e a maior parte destes ensaios podem ser registrados por meio de curvas de tensão versus deformação (CANEVAROLO JÚNIOR, 2003).

\subsubsection{Resistência à tração}

Nos ensaios de tração, os corpos de prova são afixados em dispositivos chamados de garras. Essas garras são a de travessa fixa e travessa móvel da Máquina Universal de Ensaios. A taxa de deformação de traço é controlada pelo mecanismo de direcionamento, enquanto a tensão de tração sustentada pela amostra é registrada, pela cédula de carga, ambos acoplados à travessa fixa. Neste ensaio podem-se observar três principais comportamentos (CANEVAROLO JÚNIOR, 2003) descritos nos subitens a seguir:

\subsubsection{Tensão no limite do escoamento no ensaio de resistência à tração}

A tensão no limite do escoamento ou resistência à tração no escoamento é uma relação entre a força no limite de escoamento pela área do corpo de prova. É geralmente expressa em kgf/mm² ou MPa (CANEVAROLO JÚNIOR, 2003).

\subsubsection{Tensão no limite de ruptura}

A tensão no limite da ruptura ou resistência à tração na ruptura é a relação entre a força na ruptura, pela área do corpo de prova. É geralmente expressa em $\mathrm{kgf} / \mathrm{mm}^{2}$ ou MPa (CANEVAROLO JÚNIOR, 2003). 


\subsubsection{Deformação relativa na ruptura}

A deformação relativa na ruptura, ou, deformação máxima na ruptura, é a relação entre os comprimentos finais e iniciais do corpo de prova, em relação ao comprimento inicial, expresso em porcentagem (\%) (CANEVAROLO JÚNIOR, 2003).

\subsection{Espectrometria no Infravermelho}

A chamada radiação infravermelha corresponde à parte do espectro eletromagnético situada entre as regiões do visível e das microondas. A porção de maior

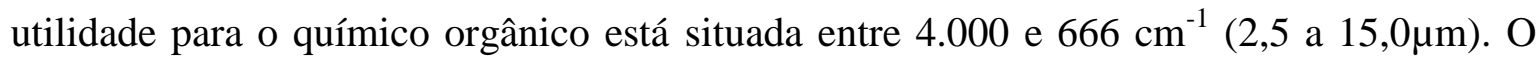
interesse nas regiões do infravermelho próximo, $14.290-4.000 \mathrm{~cm}^{-1}(0,7-2,5 \mu \mathrm{m})$, e do infravermelho distante, $700-200 \mathrm{~cm}^{-1}(14,3-50 \mu \mathrm{m})$, recentemente vem aumentando muito (SILVERSTEIN, BASSLER, MORRILL, 1979).

Embora o espectro no infravermelho seja característico da molécula como um todo certos grupos de átomos dão origem a bandas que ocorrem em uma frequência aproximada, independentemente da estrutura da molécula. É justamente a presença destas bandas características de grupos que permite ao químico a obtenção, por meio do simples exame do espectro informações estruturais úteis, e é neste fato que é realizada a identificação das estruturas.

A radiação infravermelha de frequência na faixa de $10.000-100 \mathrm{~cm}^{-1}$ ( 1 a $100 \mu \mathrm{m}$ ) quando absorvida converte-se em energia de vibração molecular. O processo também é quantizado, porém o espectro vibracional costuma aparecer como uma série de bandas ao invés de linhas porque a cada mudança de energia vibracional corresponde a uma série de mudanças de energia rotacional. As linhas se sobrepõem dando lugar às bandas observadas. São estas bandas de vibração-rotação, em particularidade as que ocorrem entre 4.000 e $666 \mathrm{~cm}^{-1}$, que se utilizou neste estudo. A frequência ou o comprimento de onda de uma absorção depende das massas relativas dos átomos, das constantes de força de ligações e da geometria dos átomos (SILVERSTEIN, BASSLER, MORRILL, 1979).

As posições das bandas no espectro infravermelho apresentam-se indiscriminadamente em comprimento de onda $(\lambda)$ ou número de ondas. Recentemente prefere-se utilizar a unidade número de ondas $\left(\mathrm{cm}^{-1}\right)$ proporcional à energia. 
As intensidades das bandas são expressas como transmitância (T) ou absorbância (A). A transmitância é a razão entre a energia radiante transmitida por amostra e a energia radiante que nela incide. A absorbância é o logaritmo, na base 10, do recíproco da transmitância, ou seja, $A=\log _{10}(1 / T)$. Regularmente publica-se uma compilação da nomenclatura oficial em espectroscopia (SILVERSTEIN, BASSLER, MORRILL, 1979).

Existem dois tipos de vibrações moleculares: as deformações axiais e as deformações angulares. Uma vibração de deformação axial é um movimento rítmico ao longo do eixo da ligação, de forma a que a distância interatômica aumente e diminua alternadamente. As vibrações de deformação angular são correspondentes as variações de ângulos de ligação, seja internamente em um grupo de átomos em relação à molécula como um todo. Desse modo, exemplifica-se a deformação angular assimétrica fora do plano e as vibrações torcionais pertencentes a esta última categoria envolve uma mudança nos ângulos de ligação referentes a um conjunto de coordenadas colocadas de modo arbitrário na molécula (SILVERSTEIN, BASSLER, MORRILL, 1979).

\subsection{Microscopia Eletrônica de Varredura, MEV}

As várias técnicas de microscopia eletrônica são atualmente as principais ferramentas disponíveis para o estudo da estrutura fina e da morfologia de materiais. Suas principais versões são: microscopia eletrônica de transmissão (TEM), de varredura (MEV) e de transmissão com varredura (STEM) (CANEVAROLO JÚNIOR, 2003).

O tamanho da estrutura a ser analisada habitualmente determina o tipo de instrumento a ser utilizado. Microscópios ópticos garantem a visualização de detalhes em escala micrométrica, assim como os microscópios eletrônicos de varredura de alta resolução, cujo feixe é produzido por emissão de campo (FESEM), podem resolver detalhes menores que 1 nanômetro conforme apresentado na TAB. 4 (CANEVAROLO JÚNIOR, 2003). 
TABELA 4 - Exemplos das principais características de microscópios ópticos (MO) e eletrônicos convencionais, com o intuito de comparação

\begin{tabular}{c|c|c|c}
\hline Técnica & OM & MEV & $\begin{array}{c}\text { TEM } \\
\text { (STEM) }\end{array}$ \\
\hline Resolução & $200 \mathrm{~nm}$ & $10 \mathrm{~nm}$ & $0,2 \mathrm{~nm}$ \\
\hline Ampliação & $2-2.000$ & $20-100.000$ & $200-2.000 .000$ \\
\hline Observação & $\begin{array}{c}\text { Interior ou } \\
\text { superfície }\end{array}$ & $\begin{array}{c}\text { Superfície } \\
\text { Interior ou } \\
\text { superfície }\end{array}$ \\
\hline Meio & Ambiente & $\begin{array}{c}\text { Alto vácuo ou baixo } \\
\text { vácuo }\end{array}$ & Alto vácuo \\
\hline $\begin{array}{c}\text { Preparação da } \\
\text { Amostra }\end{array}$ & Fácil & Fácil & Difícil \\
\hline Análise & IV* & Raios X & Raios X \\
\hline Química & Raman & & EELS** \\
\hline
\end{tabular}

*IV Espectroscopia na região do infravermelho

**EELS Espectroscopia de perda de energia de elétrons

Fonte: CANEVAROLO JÚNIOR, 2003.

\subsubsection{Interações entre elétrons e amostra}

As diferentes técnicas de microscopia eletrônica baseiam-se nos diferentes sinais produzidos pela interação dos elétrons com a amostra. Em todos os tipos de microscópios os elétrons primários, emitidos pela fonte, atingem a amostra e os mesmos elétrons, ou diferentes, escapam para formar a imagem. Por consequência, é muito importante conhecer as interações que são possíveis entre esses elétrons de alta energia e a amostra. Sem o entendimento não se torna possível à interpretação da imagem, do padrão de difração ou do espectro de energia que cada tipo de microscópio produz (CANEVAROLO JÚNIOR, 2003).

\subsubsection{Microscópio Eletrônico de Varredura}

O microscópio eletrônico de varredura é, inconfundivelmente, o microscópio mais versátil, devido às suas várias características. É comumente utilizado para o estudo de estruturas superficiais ou superfícies de amostras com dimensões relativamente grandes. As imagens têm alta profundidade de foco, o que significa obtenção de diferentes relevos da superfície da amostra de forma simultânea em foco.

São imagens tridimensionais e, contudo, mais fáceis de interpretar que as imagens de projeção de microscopia de transmissão. A SEM também produz imagens de alta resolução, o que garante a obtenção de alta ampliação de detalhes próximos sem perda de nitidez. A preparação de amostras e a obtenção de imagens são relativamente simples. A 
combinação das características dá justificativa ao fato do microscópio eletrônico de varredura ser atualmente um dos equipamentos mais utilizados na pesquisa de materiais.

Na FIG. 9 é mostrado um diagrama esquemático dos componentes de um microscópio eletrônico de varredura (CANEVAROLO JÚNIOR, 2003).

A coluna do microscópio consiste de uma fonte de elétrons, lentes eletromagnéticas e bobinas de varredura, operando sob o vácuo. A fonte de elétrons costumeiramente um tipo de filamento de tungstênio, produz elétrons que são acelerados a uma energia na faixa de 1 a $40 \mathrm{keV}$, com correntes entre $10^{-6}$ e $10^{-12} \mathrm{~A}$. O diâmetro do feixe produzido diretamente pela fonte de elétrons convencional é muito grande para gerar uma imagem definida de alta ampliação. As lentes eletromagnéticas, em conjunto com os diafragmas, são utilizadas para reduzir o diâmetro do feixe e focalizá-lo sobre a superfície da amostra. Ao atingir a amostra, o feixe de elétrons deve ter tamanho menor que 10nm e corrente suficiente para formar uma imagem definida. As bobinas de varredura têm como função defletir o feixe e controlar sua varredura sobre a superfície da amostra, conforme mostrado na FIG. 9 (CANEVAROLO JÚNIOR, 2003).

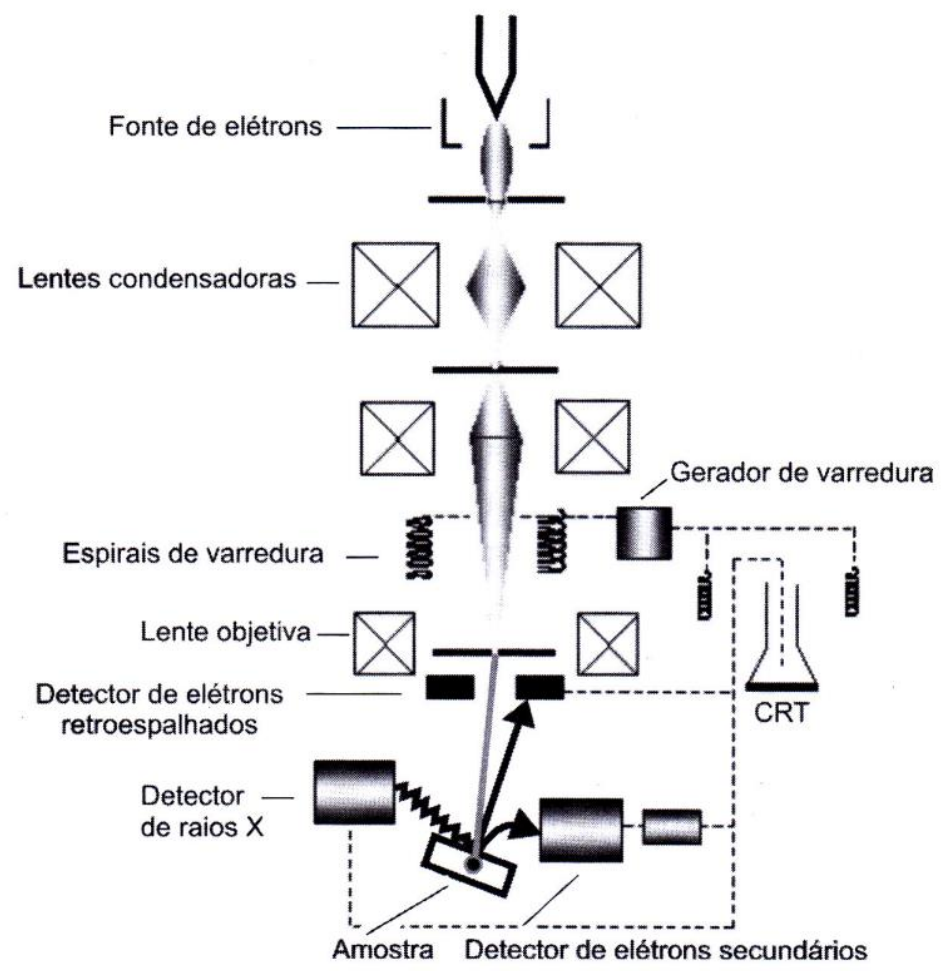

FIGURA 9 - Diagrama esquemático mostrando os principais componentes de um microscópio eletrônico de varredura 
No microscópio de varredura, a imagem é formada a partir da coleta de um sinal particular em função da posição do feixe sobre a amostra. No caso da detecção de elétrons secundários, que são formadores mais habituais de imagem, onde é produzido um sinal elétrico a cada ponto varrido na superfície da amostra.

\subsubsection{Formação da Imagem}

A irradiação da amostra com elétrons provoca a emissão de elétrons secundários, elétrons retroespalhados e de raios X, além de outros sinais. Os microscópios eletrônicos de varredura costumeiramente possuem detectores de elétrons secundários e retroespalhados na obtenção de imagens, que são sinais de rotina utilizados no estudo de materiais. Já os detectores de raios $\mathrm{X}$ são utilizados mais exclusivamente para análise química (CANEVAROLO JÚNIOR, 2003).

No microscópio eletrônico de varredura a característica da imagem topográfica gerada é semelhante à que se obtém na observação de uma superfície de uma amostra em ângulo reto, simultaneamente em que a mesma está sendo iluminada por uma fonte de luz direcionada a $45^{\circ}$. A sua aparência final, contudo, irá depender da interação envolvida, do tipo de detector e do processador de sinal usado.

Assim como, apenas a radiação que consegue escapar da superfície e ser detectada irá determinar a resolução especial da imagem.

Esta nova região da amostra define o volume de amostragem, que por sua vez depende do tipo de sinal e da composição da amostra, conforme mostrado na FIG. 10 (CANEVAROLO JÚNIOR, 2003). 


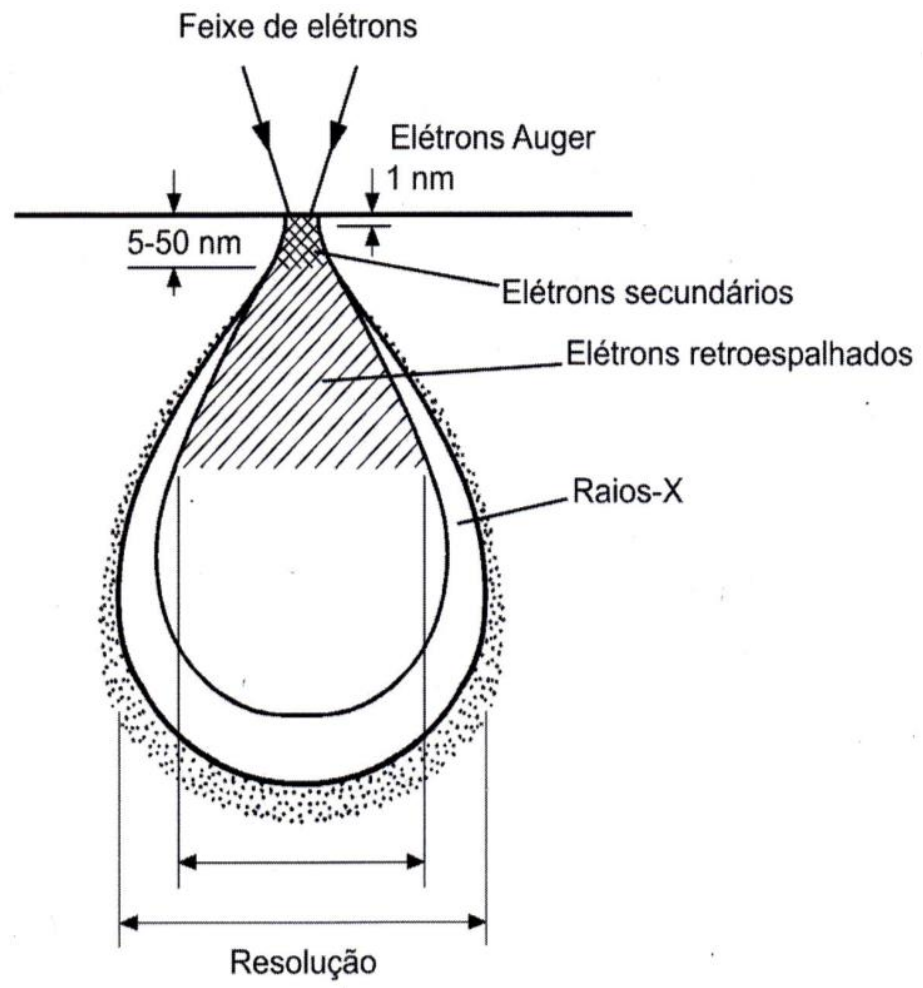

FIGURA 10 - Volume de integração e regiões onde são detectados elétrons secundários, retroespalhados $\mathrm{e}$ raios $\mathrm{X}$

A resolução espacial é, então, determinada pelo tamanho da região da amostra onde o sinal é gerado. Como elétrons secundários têm baixa energia, somente poderão escapar da amostra aqueles que forem gerados próximos da superfície. Neste caso, a emissão ocorre a partir de uma camada de poucos nanômetros da superfície da amostra. Exemplificando, a profundidade de escape em ouro, um recobrimento usado rotineiramente para amostras poliméricas, é de cerca de 1nm (CANEVAROLO JÚNIOR, 2003).

Entretanto, elétrons retroespalhados têm alta energia e mesmo aqueles produzidos em profundidades de $1 \mu \mathrm{m}$ ou mais têm a capacidade de escapar e serem detectados. Por causa desta diferença nos volumes de amostragem, a resolução espacial de imagens de elétrons retroespalhados é sempre menor que a de elétrons secundários, em condições análogas de análise. Pode-se dizer também, que imagens de retroespalhados contêm informações sobre as camadas mais profundas da amostra (CANEVAROLO JÚNIOR, 2003).

O contraste da imagem em MEV relaciona-se com o rendimento de elétrons secundários, que é função do ângulo formado entre o feixe de elétrons primários e a superfície da amostra: a intensidade de elétrons secundários será pequena se o feixe de elétrons incidirem proporcionalmente à superfície e será alta se o ângulo com a superfície 
for pequeno. A maior capacidade de emissão e detecção de elétrons secundários é, geralmente, observada nos pontos mais altos da amostra, uma vez que estes estão mais expostos ao feixe e ao detector. Desse modo, as regiões proeminentes da amostra têm grande capacidade de emissão de elétrons e irão aparecer claras na imagem; já os pontos de menor capacidade de emissão serão mais escuros. Uma amostra revestida com um filme condutor será apresentada pela emissão de elétrons secundários provenientes deste filme, como também da subcamada correspondente ao volume de amostragem (CANEVAROLO JÚNIOR, 2003).

\subsubsection{Preparação de Amostras}

$\mathrm{O}$ aspecto mais atrativo da MEV é a facilidade de preparação de amostra. Materiais não condutores, como em grande parte dos polímeros, requerem geralmente apenas revestimentos condutivos ou o uso de baixa voltagem de aceleração do feixe. Assim como a topografia da superfície é de forma geral a principal característica de interesse na análise, a espessura da amostra não é um aspecto crítico, como ocorre em microscopia eletrônica de transmissão. A montagem de amostra é feita sobre suportes metálicos, usando adesivos condutivos, por exemplo, fitas de carbono ou suspensões coloidais de prata ou carbono. O revestimento da amostra por um filme condutor tem como objetivo evitar o acúmulo de carga negativa, no caso da mesma ser formada por um material não condutor. A camada de metal deve ser suficientemente contínua e fina (menor que $20 \mathrm{~nm}$ ) para não mascarar a topografia da superfície, contudo deve ser adequada para conduzir o excesso de carga negativa. A evaporação do metal e a metalização por "sputtering" são técnicas mais habituais para esta finalidade. Os metais mais usados são ouro, liga ouro-paládio, platina, alumínio e carbono (CANEVAROLO JÚNIOR, 2003).

As amostras de pneus inservíveis de automóvel em grânulos foram recobertas com ouro, enquanto as amostras dos corpos de prova incorporados com pó de pneus inservíveis automotivos não irradiados e irradiados foram recobertas com carbono. 


\section{MATERIAL E MÉTODOS}

\subsection{Material}

Foram utilizados neste trabalho grânulos e pó de borracha de pneus inservíveis de automóvel, densidade específica de $0,907 \mathrm{~g} / \mathrm{cm}^{3}$ doados pela empresa RECICLANIP que é uma instituição responsável pela coleta e destinação de pneus inservíveis de automóvel no Brasil.

As amostras de pneus a serem estudadas em diferentes doses de radiação foram:

- Grânulos de borrachas de pneus inservíveis de automóvel de 2mm.

Para a confecção dos corpos de prova para os ensaios mecânicos foram utilizados:

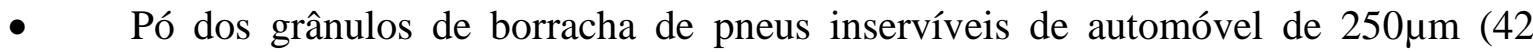
mesh);

- $\quad$ Matriz de borracha natural não vulcanizada.

Os aditivos e aceleradores utilizados para a vulcanização das placas para a confecção dos corpos de prova foram doados pela empresa: Indústria de Artefatos de Borracha Esper Ltda.:

- $\quad$ Óxido de Zinco

- $\quad$ Ácido Esteárico

- $\quad$ Enxofre

- $\quad$ MBTS: Mercapto Benzotiazol Sulfenamina

- $\quad$ TMTD: Dissulfeto Tetrametil Tiuran

\subsection{Métodos}

Para a separação da borracha do pneu foi necessário submetê-lo a processos industriais, onde primeiramente passou por lavagem e depois foi separada a malha de aço e o nylon, por esteiras. Posteriormente o pneu passou por um processo de moagem utilizando-se granuladores, até chegar a espessura de grânulos de $2 \mathrm{~mm}$. 


\subsubsection{Preparação das amostras em grânulos para irradiação}

Os grânulos de borracha de pneus inservíveis foram separados e colocados em pirex de vidro e submetidos ao processo de irradiação em um acelerador industrial de elétrons tipo Dynamitron, da Radiation Dynamics Inc., modelo DC1500/25 - JOB 188 com energia de 1,5MeV e corrente de feixe de 0,3 - 25mA, como mostrado na FIG. 11.

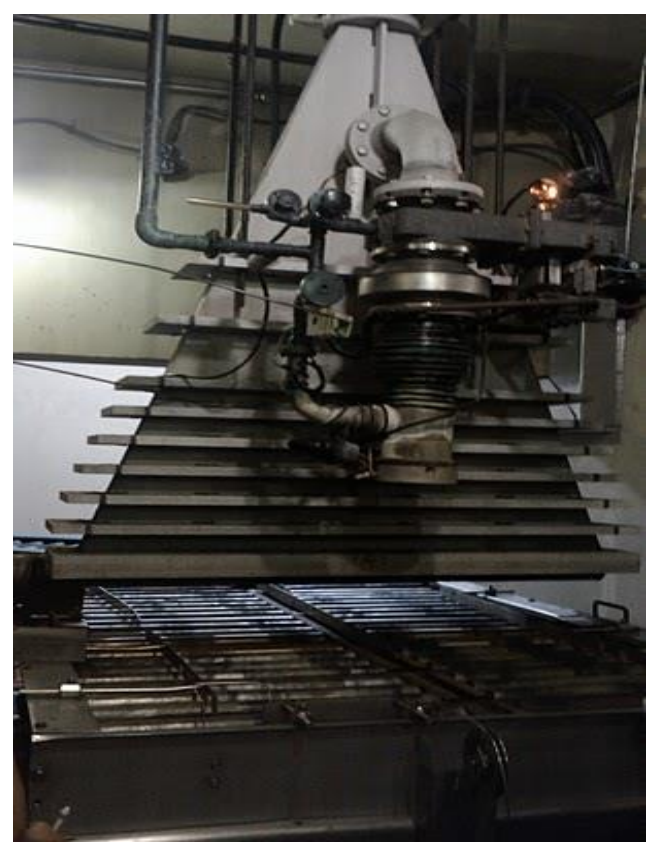

FIGURA 11 - Acelerador de elétrons Dynamitron II modelo DC 1500 JOB 188

As irradiações foram realizadas em temperatura ambiente e presença de ar, com doses de radiação de 200, 400 e 600kGy, à taxa de dose de 22,39 kGy/s. A confirmação da dose total de radiação absorvida foi realizada por dosimetria no Centro de Tecnologia das Radiações, utilizando-se dosímetros de triacetato de celulose. Após a irradiação as amostras foram acondicionadas dentro de embalagens plásticas e armazenadas em local seco, até a realização das caracterizações.

\subsubsection{Preparação das amostras em pó}

O pó de borracha de pneus inservíveis foi pesado e colocado em um conjunto de peneiras nos tamanhos $710 \mu \mathrm{m}, 355 \mu \mathrm{m}, 250 \mu \mathrm{m}$ e $125 \mu \mathrm{m}$. Posteriormente esse conjunto foi colocado sobre um agitador eletromagnético marca Bertel da Indústria Metalúrgica de peneiras granulométricas, por 5 minutos em vibração escala 5. Esse processo foi repetido mudando o tempo para 15 minutos em vibração de escala 10. Para facilitar a peneiração foi 
colocado 3 esferas de vidro de diâmetro aproximado de $1 \mathrm{~cm}$ conhecidas como (bolinhas de gude) em cada prato de peneira, o pó foi submetido por mais 10 minutos a uma vibração de escala $10,95 \%$ do pó passou da peneira de tamanho $250 \mu \mathrm{m}$, não passando pela peneira de $125 \mu \mathrm{m}$ então o pó foi considerado no tamanho de $250 \mu \mathrm{m}$, todo esse processo está mostrado na FIG. 12.

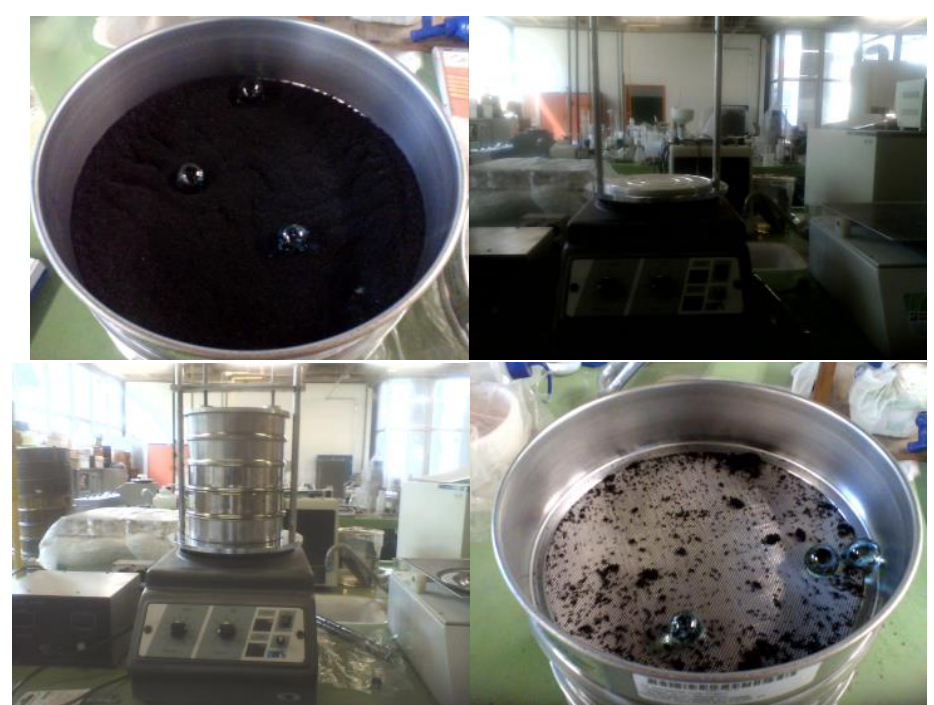

FIGURA 12 - Conjunto de peneiras nos tamanhos $710 \mu \mathrm{m}, 355 \mu \mathrm{m}, 250 \mu \mathrm{m}$ e $125 \mu \mathrm{m}$ e agitador de peneiras granulométrico eletromagnético

O pó de borracha de pneus inservíveis foi colocado em pirex e posteriormente foi secado a $50 \pm 5^{\circ} \mathrm{C}$ por 24 horas em uma estufa com circulação de ar.

\subsubsection{Incorporação dos aditivos na matriz de borracha natural}

A borracha natural foi submetida a um pré-processamento de mistura com dois aditivos o acido esteárico e o óxido de zinco. Para a incorporação destes aditivos na matriz foi utilizado um misturador aberto (cilíndrico), tipo calandra da Metalbor, na Indústria Esper LTDA, conforme mostrado na FIG. 13. 


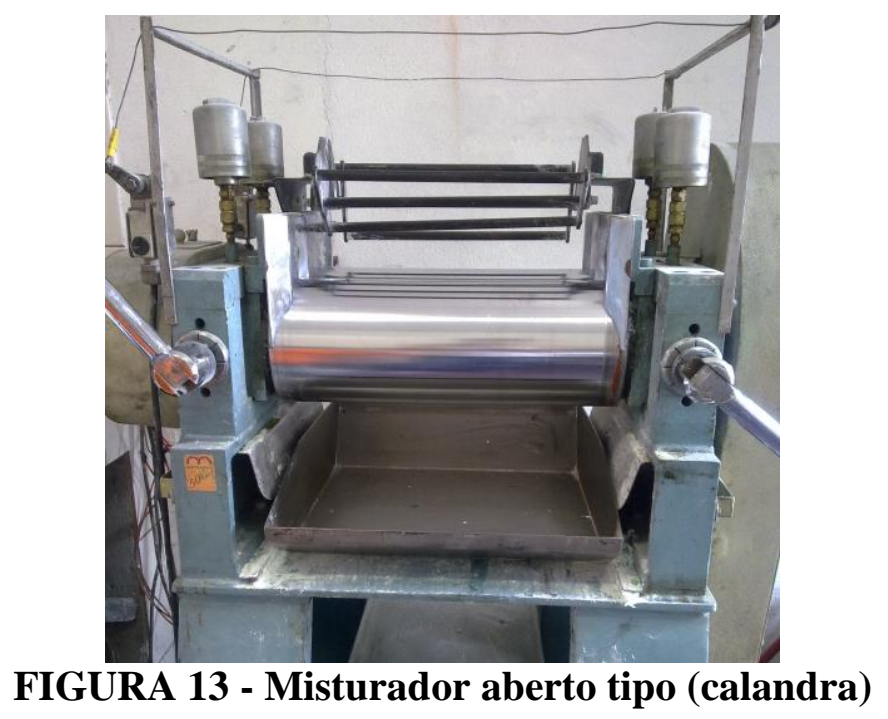

A incorporação dos aditivos foi realizada em partes conforme é mostrado na FIG. 14.

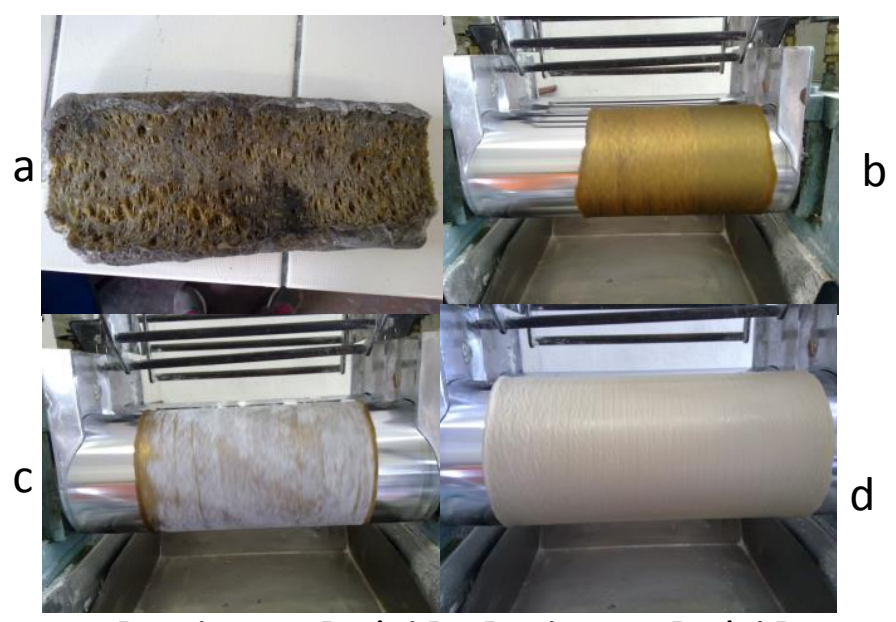

FIGURA 14 - Processo de mistura de óxido de zinco e de ácido esteárico. a) borracha natural. b) borracha natural homogeneizada. c) adição do óxido de zinco. d) borracha natural homogeneizada com acido esteárico e óxido de zinco

\subsubsection{Incorporação do pó de borracha de pneus na matriz de borracha natural}

O pó de borracha de pneus inservíveis foi misturado em diferentes porcentagens $(10 \%, 30 \%$ e 50\%) na matriz de borracha natural não vulcanizada.

Para a incorporação do pó da borracha de pneus inservíveis na matriz foi utilizado um misturador aberto (cilíndrico) tipo calandra, na Universidade Mackenzie (FIG. 15). 


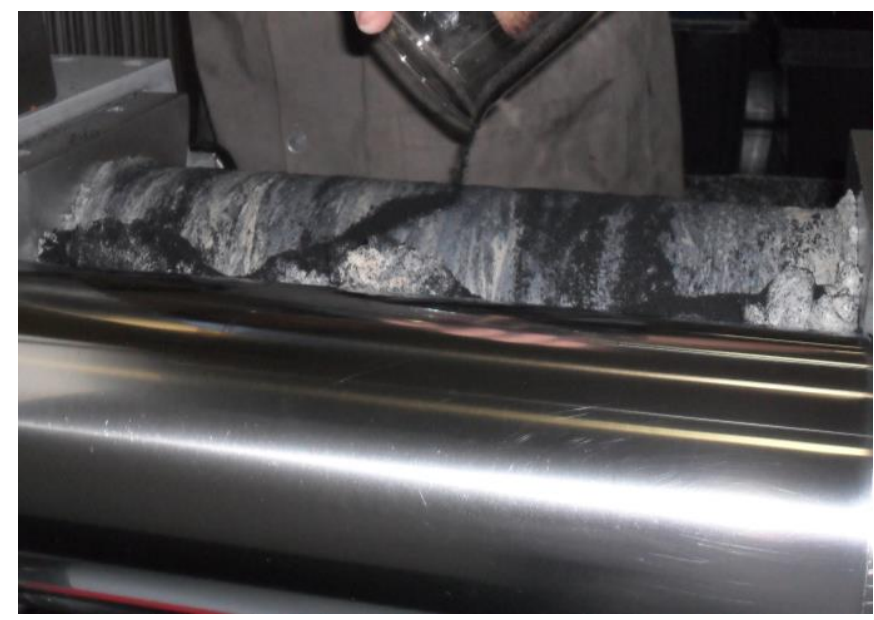

FIGURA 15 - Placa de borracha recebendo pó de borracha de pneus inservíveis de automóvel em um misturador aberto (cilíndrico) tipo calandra

As placas foram armazenadas para posterior adição de aceleradores.

\subsubsection{Adição dos aceleradores}

Após a obtenção das placas foram adicionados os aceleradores enxofre, MBTS e TMTD em cada placa, no mesmo misturador aberto tipo calandra conforme mostrado na FIG. 16. As adições foram realizadas na Universidade Mackenzie e na Indústria Esper LTDA.

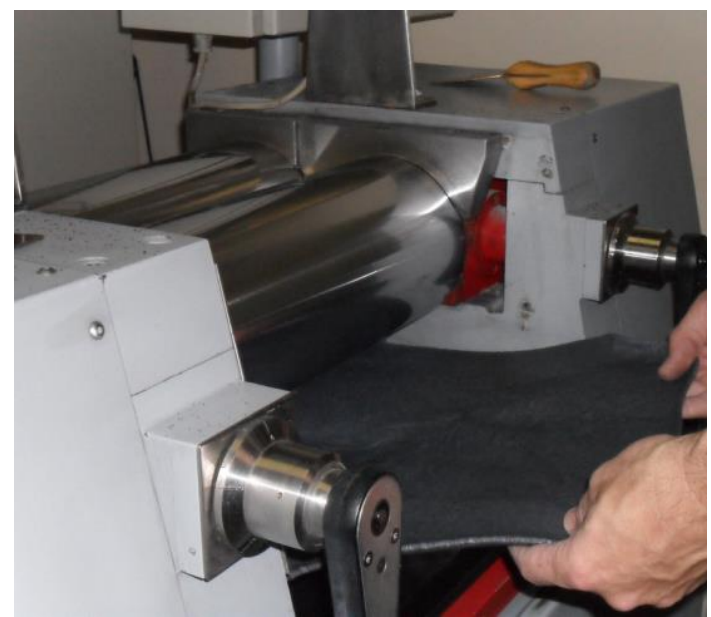

FIGURA 16 - Adição dos aceleradores na placa de borracha em um misturador aberto (cilíndrico) tipo calandra 


\subsubsection{Vulcanização e confecção dos corpos de prova}

As placas com aproximadamente $60 \mathrm{~g}$ foram vulcanizadas utilizando-se Prensa Vulcanizadora Equipamenta, tipo EQ - CV1, em temperatura entre $145^{\circ} \mathrm{C}$ e $165^{\circ} \mathrm{C}$, conforme mostrado na FIG. 17. Essas placas foram vulcanizadas na indústria Esper LTDA.

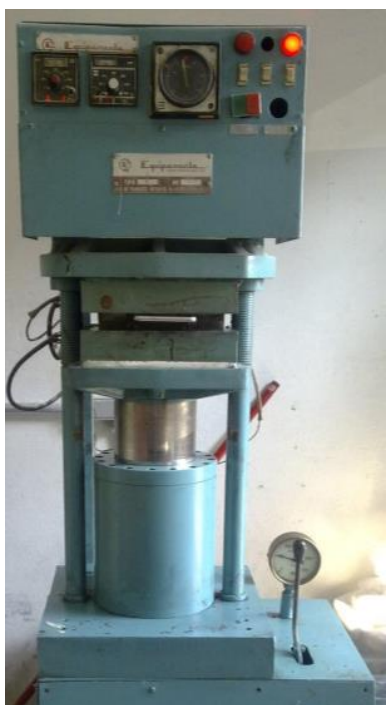

FIGURA 17 - Vulcanizadora Equipamenta, tipo EQ - CV1

Após a vulcanização foram obtidas placas de aproximadamente $50 \mathrm{~g}$ cada. Essas placas foram cortadas com um molde padrão, de acordo com a norma ASTM D 412, para a confecção dos corpos de prova para a realização dos ensaios mecânicos, conforme mostrado na FIG. 18. 

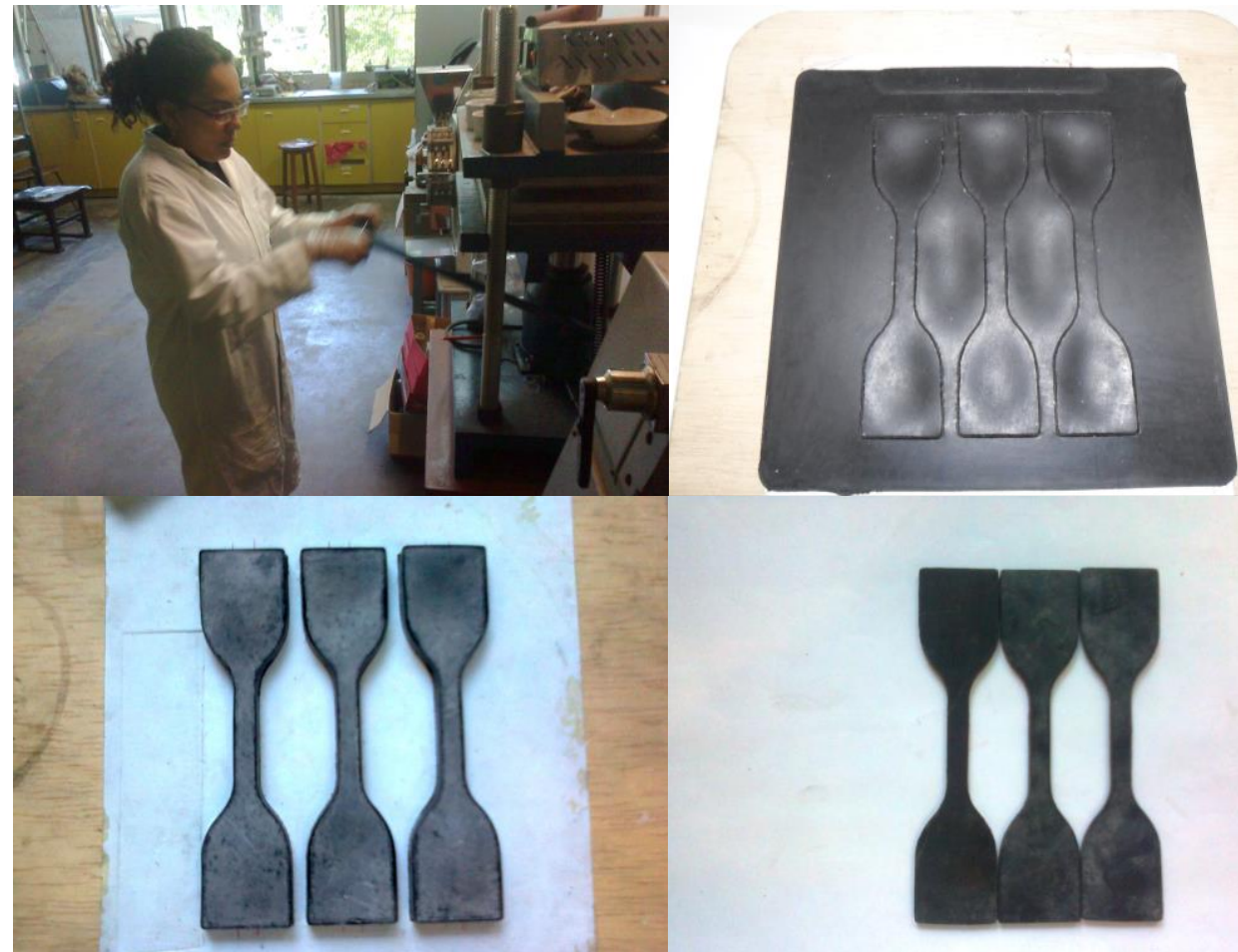

FIGURA 18 - Processo de corte dos corpos de prova

Posteriormente estes corpos de prova foram irradiados em um acelerador de elétrons como descrito no sub item 4.2.1, e fixados em porta amostra, conforme mostrado na FIG. 19.

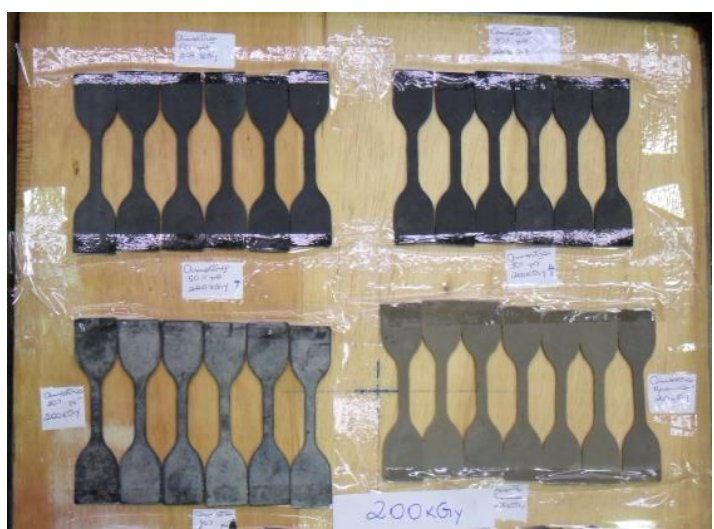

FIGURA 19 - Corpos de prova submetidos à irradiação por feixes de elétrons, nas doses de 200kGy, 400kGy e 600kGy 
4.2.7 Caracterização das amostras em grânulos e dos corpos de prova de borracha de pneus inservíveis

\subsubsection{Termogravimetria (TG)}

As amostras em grânulos de borracha de pneus inservíveis foram caracterizadas em uma termobalança modelo TGA-50 (Shimadzu, Tóquio, Japão), pertencente ao (CTR), IPEN-CNEN/SP, conforme mostrado na FIG. 20.

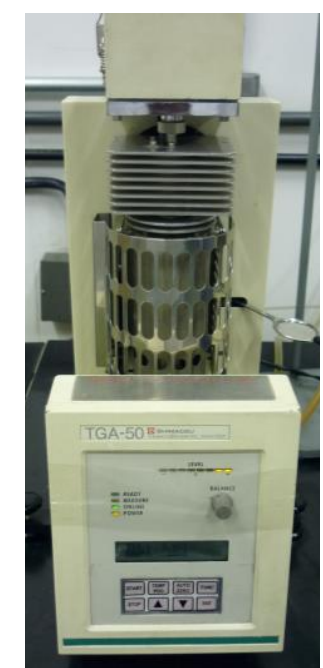

FIGURA 20 - Termobalança TGA-50 da Shimadzu, Tóquio, Japão

Os ensaios foram realizados em atmosfera de ar comprimido com vazão de $50 \mathrm{~mL} / \mathrm{min}$ e em atmosfera de nitrogênio, utilizando-se cápsula de platina, com massa de amostra de $5 \pm 0,5 \mathrm{mg}$, razão de aquecimento de $10^{\circ} \mathrm{C} / \mathrm{min}$ e temperatura limite de $600^{\circ} \mathrm{C}$.

\subsubsection{Calorimetria exploratória diferencial (DSC)}

Os ensaios de calorimetria exploratória diferencial (DSC) foram realizados nas amostras em grânulos de borracha em um calorímetro modelo DSC-50 (Shimadzu, Tóquio, Japão), pertencente ao CTR, conforme mostrado na FIG. 21. 


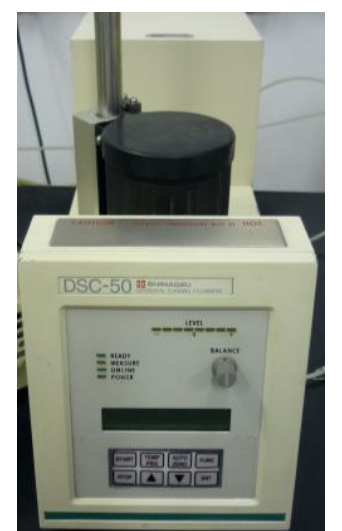

FIGURA 21 - Calorímetro exploratório diferencial DSC-50 da Shimadzu, Tóquio, Japão

Os ensaios foram realizados em atmosfera de nitrogênio com vazão de $50 \mathrm{~mL} / \mathrm{min}$, utilizando-se cápsula de alumínio semi-selada, com massa de amostra de $2 \pm$ $0,5 \mathrm{mg}$, razão de aquecimento de $10^{\circ} \mathrm{C} / \mathrm{min}$ e temperatura limite de $500^{\circ} \mathrm{C}$.

\subsubsection{Espectroscopia de absorção na região do infravermelho com transformada de Fourier (FTIR)}

Os espectros de absorção das amostras em grânulos de pneus inservíveis na região do infravermelho foram obtidos no equipamento modelo Spectrum 400, da Perkin Elmer, conforme mostrado na FIG. 22, pertencente ao CTR.

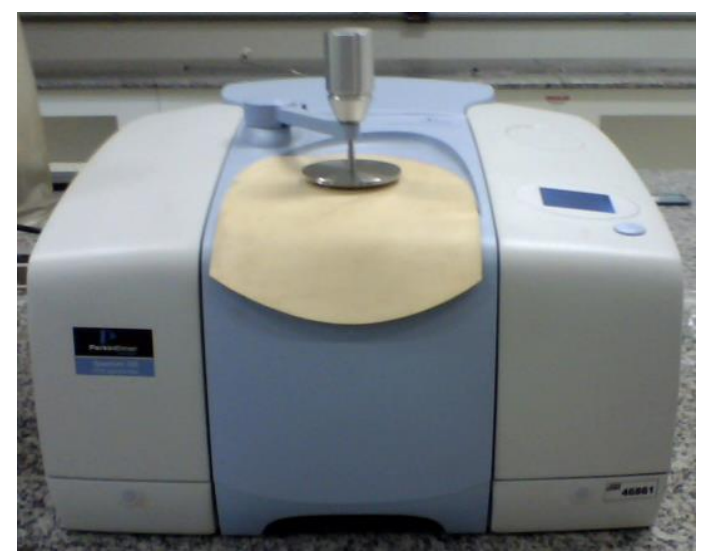

FIGURA 22 - FTIR Spectrum 400 da Perkin Elmer

Foi utilizada a técnica de refletância total atenuada (ATR). Os espectros foram observados nas regiões de $2000-650 \mathrm{~cm}^{-1}$. 


\subsubsection{Microscopia eletrônica de varredura (MEV)}

Para a realização desta análise nos grânulos de pneus inservíveis de automóvel, as amostras irradiadas e não irradiadas foram fixadas em suporte com fita dupla face de carbono. Para torná-las condutivas elas foram recobertas com uma fina camada de ouro, utilizando a evaporadora da marca Baltec Union, modelo SCD 050, localizado no Centro de Ciência e Tecnologia de Materiais (CCTM) do IPEN-CNEN/SP conforme mostrado na FIG. 23.

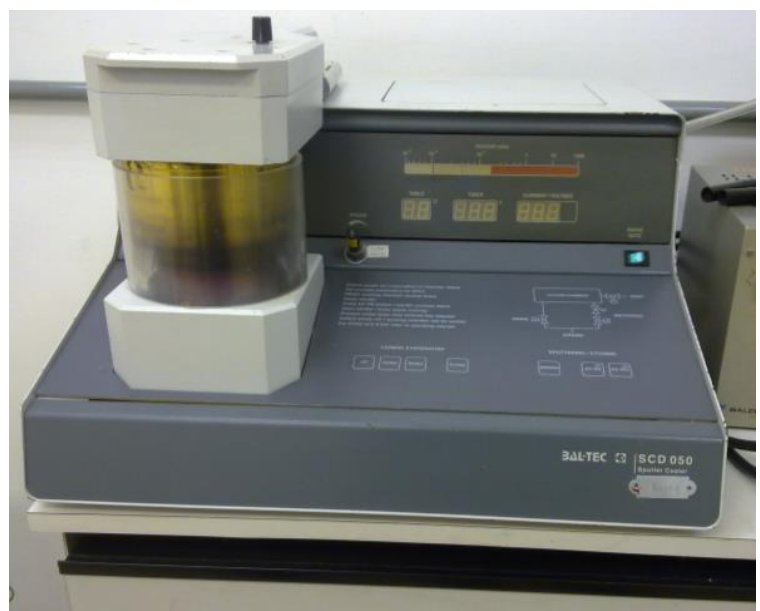

FIGURA 23 - Evaporadora da marca Baltec Union, modelo SCD 050

Posteriormente os suportes foram posicionados na câmara à vácuo do equipamento de microscopia eletrônico de varredura, marca Philips, modelo LX 30 do CCTM, conforme mostrado na FIG. 24, para determinação da morfologia da superfície das amostras.

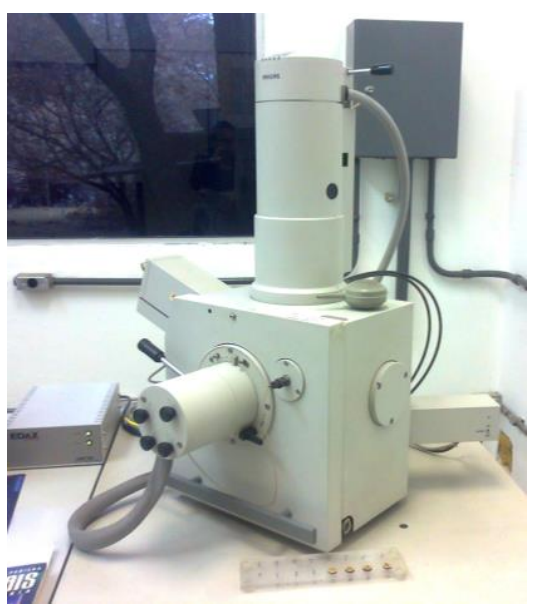

FIGURA 24 - Microscópio Eletrônico de Varredura marca Philips, modelo LX 30 
Para verificar a adesão nos corpos de prova das partículas de pó de borracha de pneus inservíveis, em diferentes porcentagens $(10,30$, e 50\%), e a matriz elastomérica, utilizou-se um microscópio eletrônico da marca HITACHI, modelo TM 3000, alocado no CCTM conforme mostrado na FIG. 25.

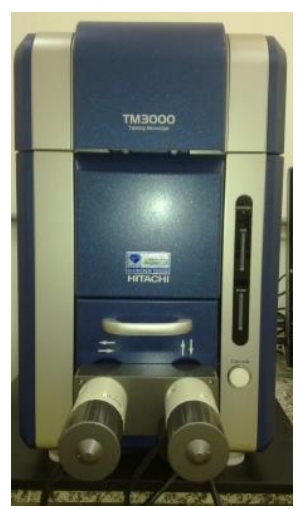

FIGURA 25 - Microscópio Eletrônico de Varredura, formato Tabletop da marca HITACHI, modelo TM 3000

\subsubsection{Ensaios de tração e alongamento}

Foram realizados ensaios de tração e alongamento nos corpos de prova sem pó e com pó de borracha de pneus inservíveis, utilizando o dinamômetro da marca INSTRON, modelo 5567, pertencente ao CTR, de acordo com a metodologia descrita na norma ASTM D 412 conforme mostrado na FIG. 26.

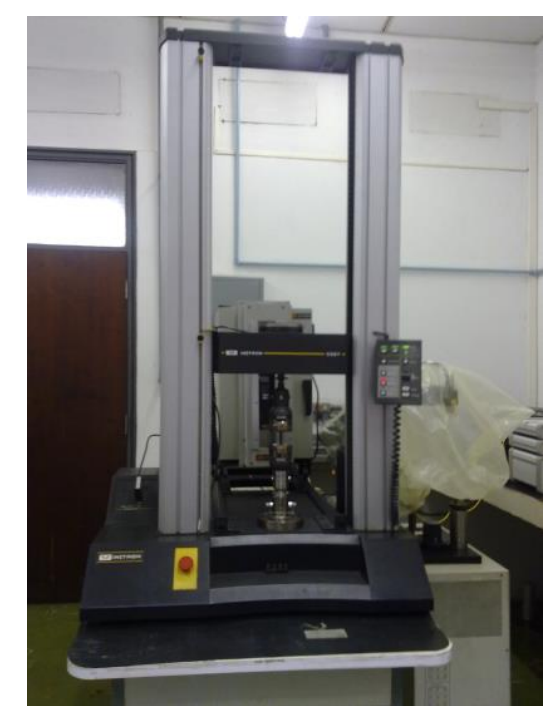

FIGURA 26 - Equipamento de ensaios mecânicos: Dinamômetro da marca INSTRON, modelo 5567

Foi utilizado uma cédula de carga de $10 \mathrm{kN}$, e velocidade de $510 \mathrm{~mm} / \mathrm{min}$. 


\section{RESULTADOS E DISCUSSÃO}

\subsection{Termogravimetria}

Na FIG. 27 são mostradas as curvas termogravimétricas na presença de oxigênio das amostras de grânulos de pneus inservíveis, não irradiada e irradiadas nas doses de 200, 400 e 600kGy. Observam-se na FIG. 27 as diferentes perdas de massa em função da dose de radiação, conforme o aumento da temperatura e a ocorrência de vários eventos de perda de massa.

Esta redução foi de $97 \%$ respectivamente para a amostra não irradiada e irradiadas com doses de 200kGy e 400kGy. Para a dose de 600kGy observou-se uma redução de até $99 \%$, como é apresentado na TAB. 5.

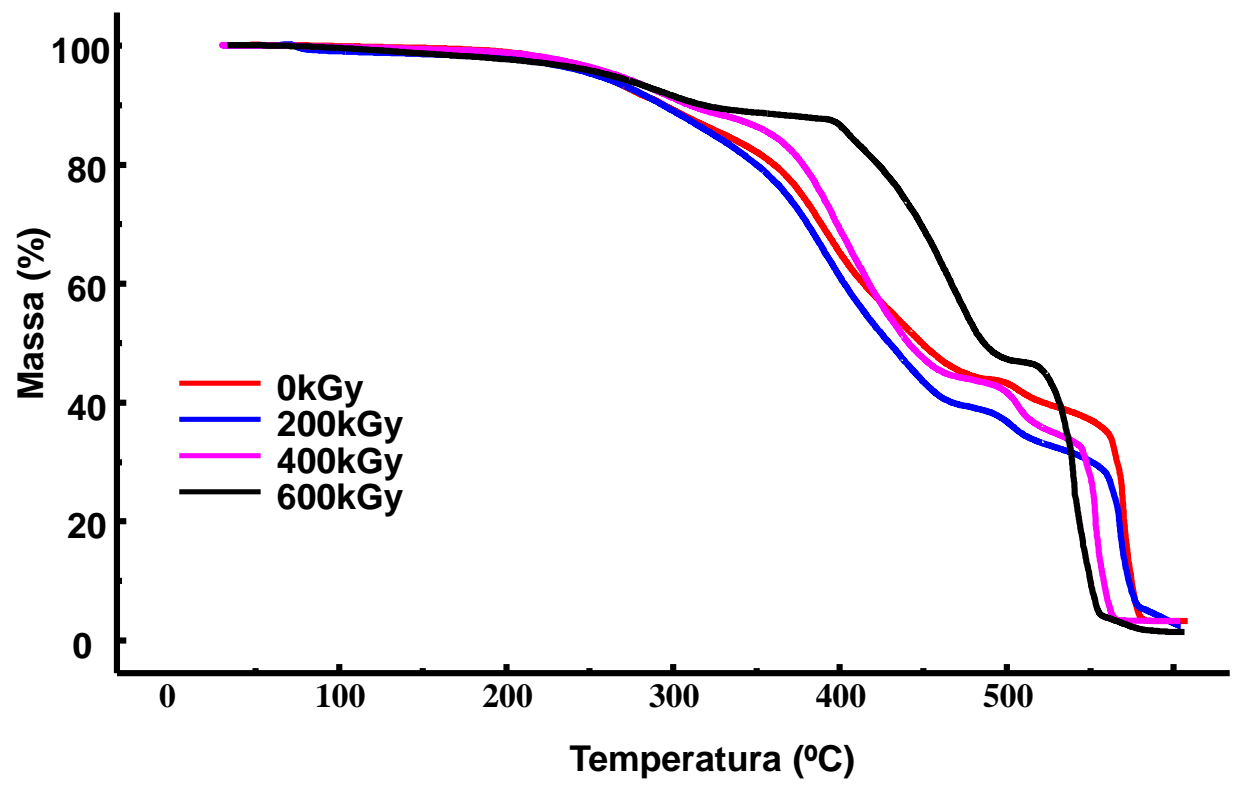

FIGURA 27 - Curvas termogravimétricas obtidas em atmosfera dinâmica de ar para as amostras de grânulos de pneus inservíveis de automóvel, não irradiada e irradiadas nas doses de $200 \mathrm{kGy}, 400 \mathrm{kGy}$ e $600 \mathrm{kGy}$, sob razão de aquecimento de $10^{\circ} \mathrm{C} / \mathrm{min}$ desde a temperatura ambiente até $600^{\circ} \mathrm{C}$

Observaram-se nas curvas, as perdas de massa conforme a temperatura dos eventos (FIG. 27) e a temperatura do início dos eventos sofreram alterações conforme cada dose de radiação conforme apresentado na TAB. 5.

Pode-se dizer que possivelmente o resíduo que ficou após a termogravimetria seja óxido de zinco, como apresentado na TAB. 5. 
TABELA 5 - Comparação em porcentagem (\%) das perdas de massa das amostras não irradiada e irradiadas, em atmosfera dinâmica de ar, com doses de radiação conforme o aumento da temperatura ambiente até $600^{\circ} \mathrm{C}$

\begin{tabular}{ccccc}
\hline & $\begin{array}{c}\text { Faixa de } \\
\text { temperatura de } \\
\text { maior perda de } \\
\text { massa } \\
\begin{array}{c}\text { Dose } \\
\mathbf{k G y}\end{array}\end{array}$ & $\begin{array}{c}\text { Perda de massa no } \\
\text { evento principal }\end{array}$ & $\begin{array}{c}\text { Perda de } \\
\text { massa } \\
\mathbf{\%}\end{array}$ & $\begin{array}{c}\text { Resíduo } \\
(\boldsymbol{\%})\end{array}$ \\
\hline $\mathbf{0}$ & $530-599$ & 36 & 96,9 & 3,1 \\
$\mathbf{2 0 0}$ & $518-599$ & 36 & 97,2 & 2,8 \\
$\mathbf{4 0 0}$ & $471-599$ & 41 & 97,8 & 2,2 \\
$\mathbf{6 0 0}$ & $382-599$ & 86 & 98,5 & 1,5 \\
\hline
\end{tabular}

Na FIG. 28 são mostradas as curvas termogravimétricas na presença de nitrogênio $\left(\mathrm{N}_{2}\right)$ das amostras de pneus inservíveis de automóvel não irradiada e irradiadas nas doses de 200, 400 e 600kGy. Observam-se, nesta FIG. 28, as diferentes perdas de massa em função da dose de radiação, conforme o aumento da temperatura.

Esta redução foi de aproximadamente $71 \%$ para a amostra não irradiada, $58 \%$ para a dose de $200 \mathrm{kGy}, 60 \%$ para a dose de $400 \mathrm{kGy}$ e $69 \%$ para a dose de $600 \mathrm{kGy}$, com o aumento da temperatura como é mostrado na TAB. 6.

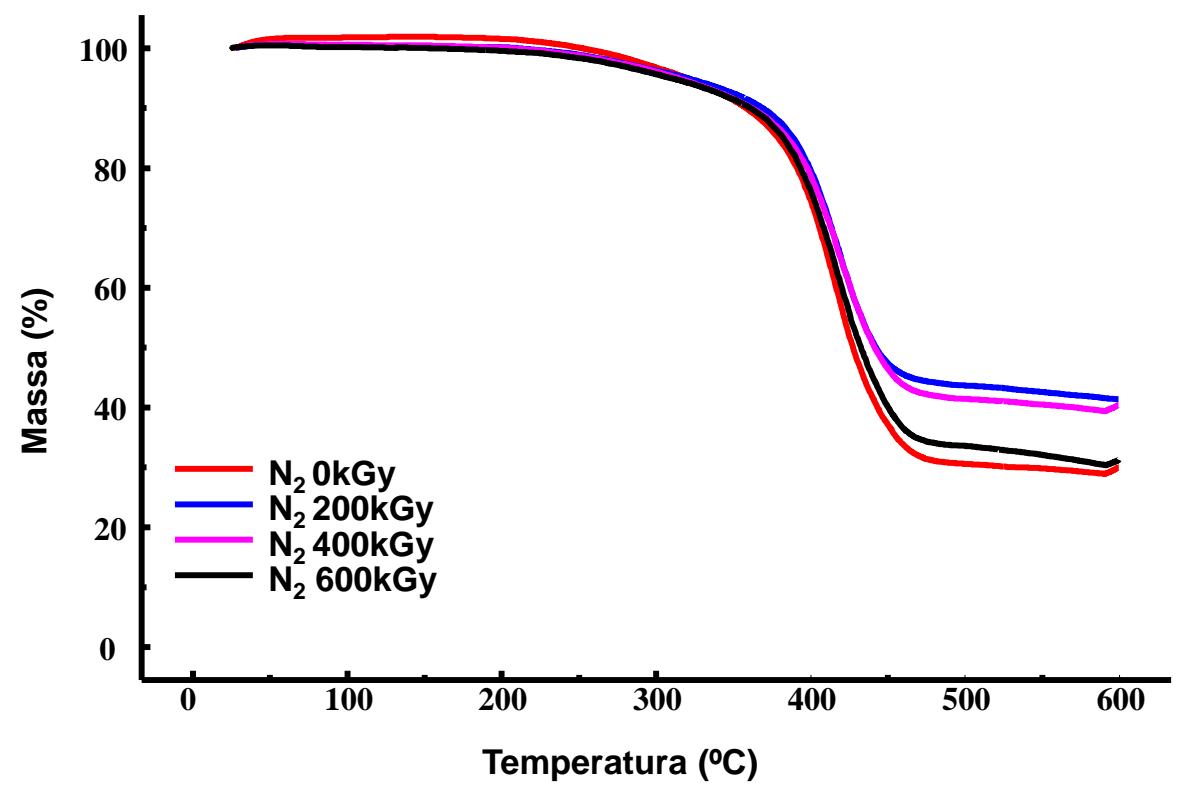

FIGURA 28 - Curvas termogravimétricas obtidas em atmosfera dinâmica de $\mathrm{N}_{2}$ para a amostra de grânulos de pneus inservíveis de automóvel, não irradiada e irradiadas com doses de $200 \mathrm{kGy}, 400 \mathrm{kGy}$ e $600 \mathrm{kGy}$

Conforme a FIG. 28, as amostras de grânulos de borracha de pneus inservíveis de automóvel quando submetidas e caracterizadas pela termogravimetria em nitrogênio 
$\left(\mathrm{N}_{2}\right)$, mostraram um só evento. Conforme cada dose a temperatura do início dos eventos não se diferem, pois não houve oxidação por se tratar de uma atmosfera inerte, porém em aproximadamente $400^{\circ} \mathrm{C}$ houve diferentes sobras de resíduo, possivelmente com o aumento da dose de radiação pode ter ocorrido alterações no comportamento térmico das amostras, mas a estabilidade térmica das amostras não sofreram alterações com o aumento da dose de radiação. Pode-se dizer que a amostra irradiada na dose de $200 \mathrm{kGy}$ e $400 \mathrm{kGy}$ tiveram a maior sobra de resíduos $41,3 \%$ e 39,9\% respectivamente. As amostras não irradiadas e irradiadas na dose de 600kGy tiveram a maior perda de massa, 70,5\% e 69,1\% respectivamente.

TABELA 6 - Comparação em porcentagem (\%) das perdas de massa das amostras de pneus inservíveis de automóvel, não irradiada e irradiadas, em atmosfera dinâmica de $\mathrm{N}_{2}$ com diferentes doses de radiação com o aumento da temperatura ambiente até $600^{\circ} \mathrm{C}$

\begin{tabular}{ccccc} 
Dose & $\begin{array}{c}\text { Intervalo de } \\
\text { temperatura do } \\
\text { evento Principal } \\
\mathbf{k G y}\end{array}$ & $\begin{array}{c}\text { Perda de massa no } \\
\text { evento principal } \\
(\mathbf{\%})\end{array}$ & $\begin{array}{c}\text { Perda de } \\
\text { massa } \\
(\boldsymbol{\%})\end{array}$ & $\begin{array}{c}\text { Resíduo } \\
\mathbf{( \% )}\end{array}$ \\
\hline $\mathbf{0}$ & $300-499$ & 66 & 70,5 & 29,5 \\
$\mathbf{2 0 0}$ & $211-485$ & 56 & 58,7 & 41,3 \\
$\mathbf{4 0 0}$ & $179-489$ & 58 & 60,1 & 39,9 \\
$\mathbf{6 0 0}$ & $162-490$ & 66 & 69,1 & 30,9 \\
\hline
\end{tabular}

\subsection{Calorimetria exploratória diferencial}

Nas curvas de DSC são apresentados os comportamentos térmicos das amostras de grânulos de borracha de pneus inservíveis de automóvel. Os componentes das amostras reagem quimicamente devido a energia térmica. A área dos picos observadas é proporcional às entalpias envolvidas nas reações. No caso de se tratarem de eventos exotérmicos, pois foi considerado no DSC fluxo de calor, em geral a diferença $T_{A}-T_{R}$ serve de base para cálculo do calor absorvido ou liberado pela amostra, e o resultado será positivo $(\Delta \mathrm{T}>0)$ para os eventos exotérmicos.

Foi observado na FIG. 29, um pico em aproximadamente $394^{\circ} \mathrm{C}$ e outro em $435^{\circ} \mathrm{C}$. Pode-se dizer que os picos observados na curva DSC são exotérmicos, pois a energia produzida no processo pode ser considerada de decomposição da amostra. Foram 
calculados os valores de variação de entalpia na área dos picos em função da dose de radiação.

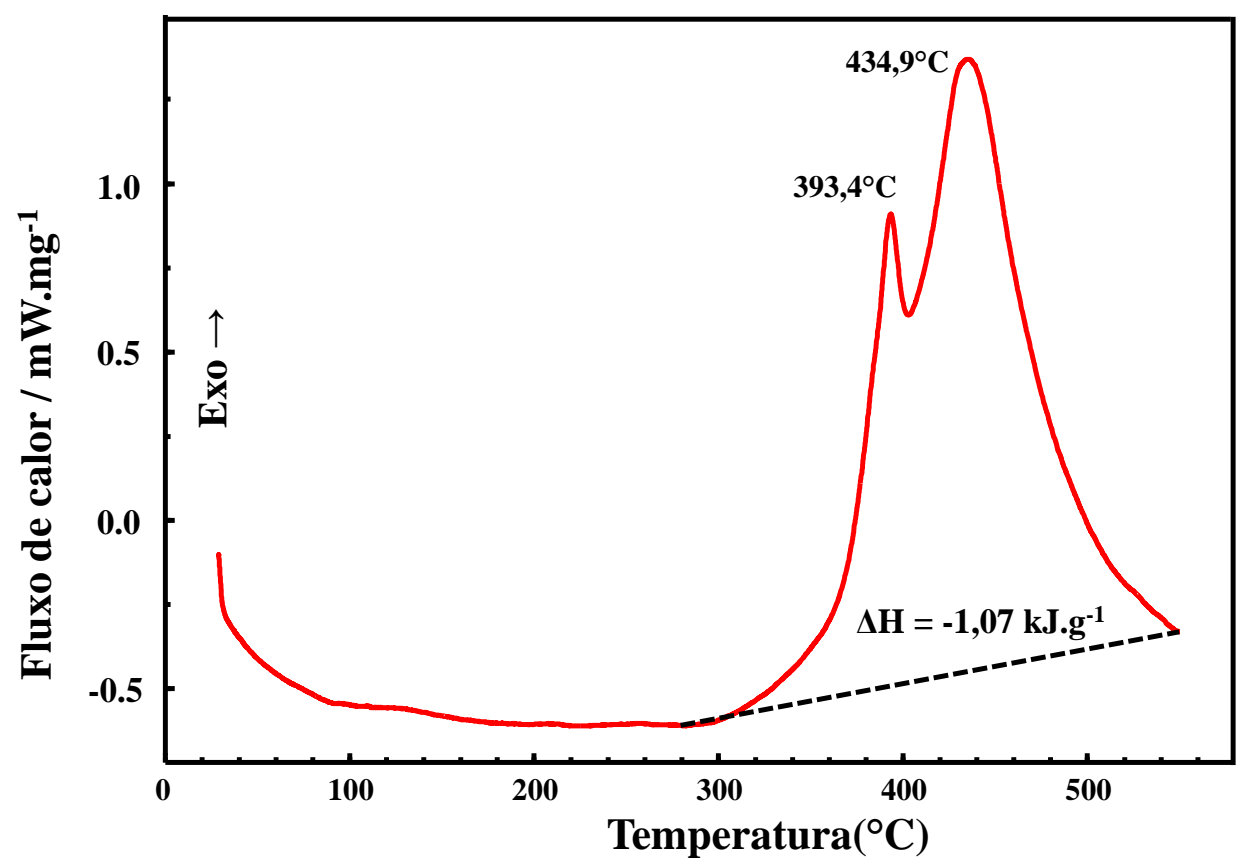

FIGURA 29 - Curva DSC obtida em atmosfera dinâmica de $\mathrm{N}_{2}$ para a amostra de grânulos de pneus inservíveis de automóvel não irradiada

Foi observado na FIG. 30, um pico em aproximadamente $395^{\circ} \mathrm{C}$ e outro pico em $439^{\circ} \mathrm{C}$. Pode-se dizer que os picos observados na curva DSC são exotérmicos, pois a energia produzida no processo pode ser considerada decomposição dos materiais. Foram calculados os valores de variação de entalpia na área dos picos em função da dose de radiação. 


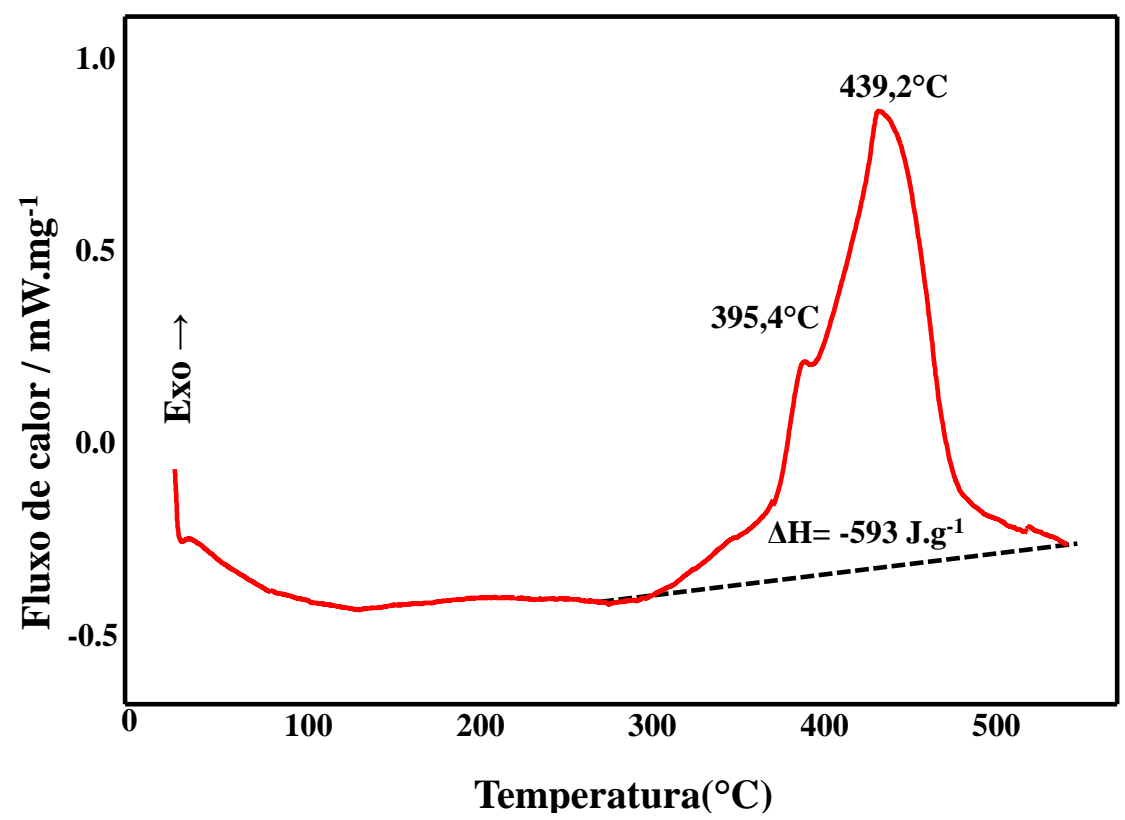

FIGURA 30 - Curva DSC obtida em atmosfera dinâmica em $\mathrm{N}_{2}$ para a amostra de grânulos de pneus inservíveis de automóvel irradiada na dose de $200 \mathrm{kGy}$

Foi observado na FIG. 31, um pico em aproximadamente $383^{\circ} \mathrm{C}$ e outro pico aproximadamente em $437^{\circ} \mathrm{C}$. Pode-se dizer que os picos observados na curva DSC são exotérmicos, pois a energia produzida no processo pode ser considerada decomposição. Foi calculado os valores de entalpia na área dos picos em função da dose de radiação.

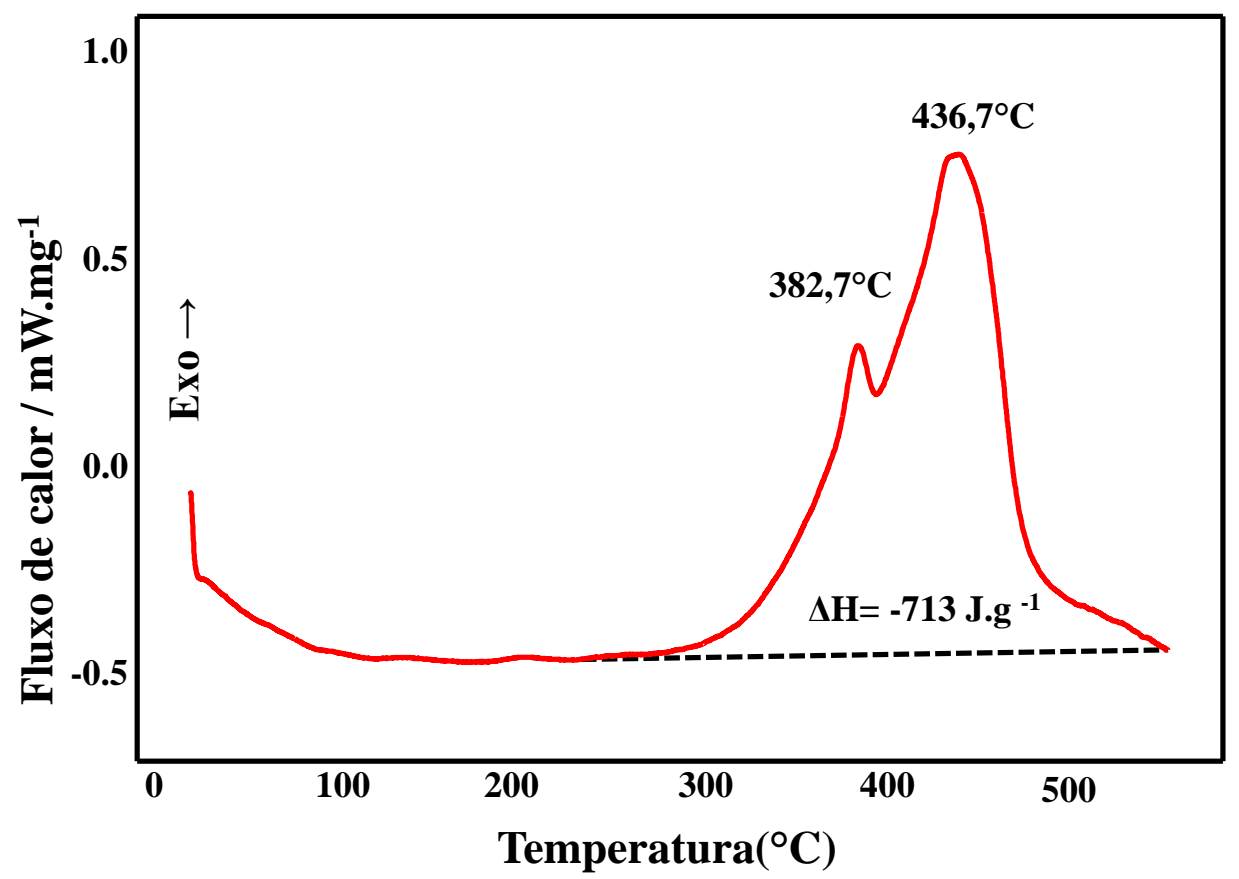

FIGURA 31 - Curva DSC obtida em atmosfera dinâmica em $\mathbf{N}_{2}$ para a amostra de grânulos de pneus inservíveis de automóvel irradiada na dose de 400kGy 
Foi observado na FIG. 32, um pico em aproximadamente $381^{\circ} \mathrm{C}$ e outro pico aproximadamente em $435^{\circ} \mathrm{C}$. Pode-se dizer que os picos observados na curva DSC são exotérmicos, pois a energia produzida no processo pode ser considerada decomposição. Foi calculado os valores de entalpia a partir da área dos picos em função da dose de radiação.

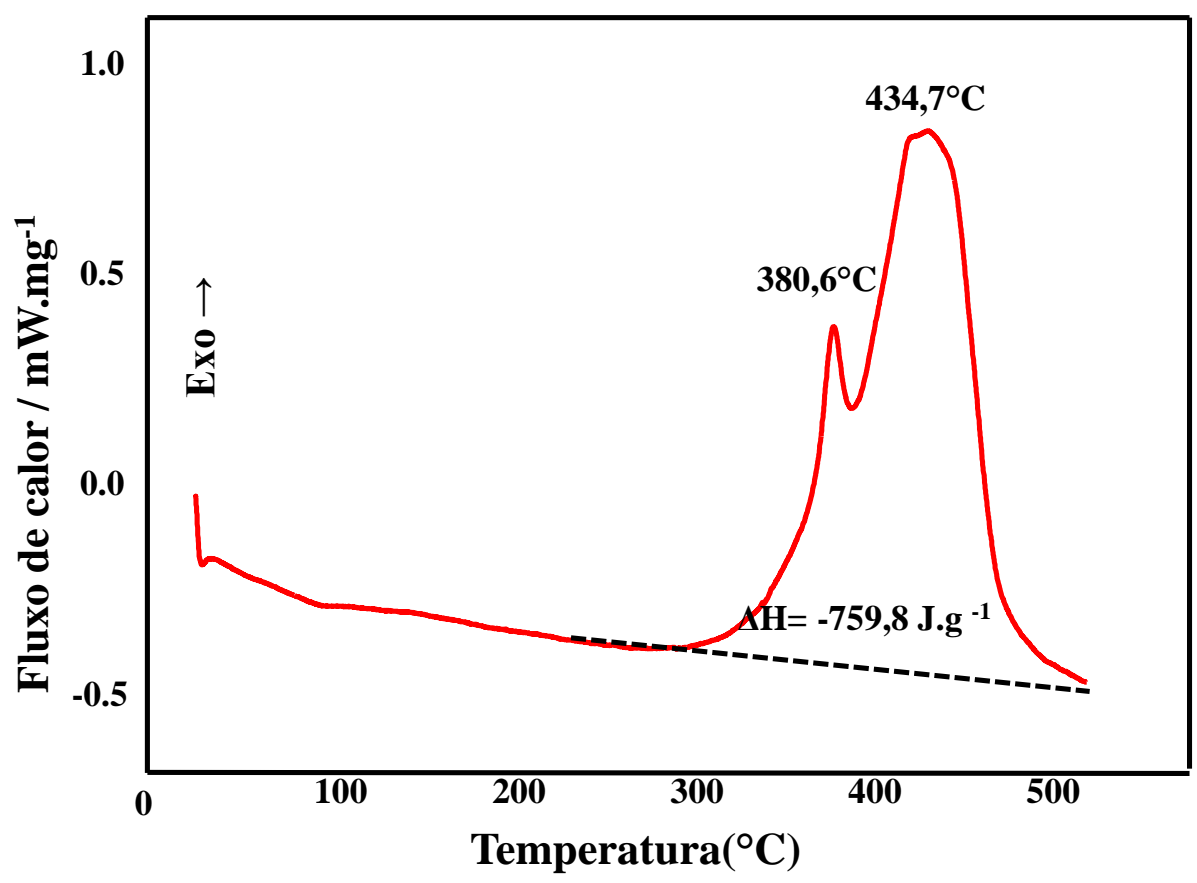

FIGURA 32 - Curva DSC obtidas em atmosfera dinâmica em $\mathbf{N}_{2}$ para a amostra de grânulos de pneus inservíveis de automóvel irradiada na dose de $600 \mathrm{kGy}$

\subsection{Ensaios mecânicos}

Na FIG. 33 são mostrados os resultados da porcentagem de deformação máxima na ruptura para as amostras de borracha sem pó de pneus inservíveis, irradiadas e não irradiadas. Pode-se observar, nesta FIG. 33, redução da porcentagem de deformação original das amostras de borracha sem pó de pneus inservíveis, à medida que se aumentou a dose de radiação. Observou-se também nesta FIG. 33 que as amostras irradiadas com a dose de $600 \mathrm{kGy}$ apresentaram maior redução, uma vez que a média de deformação original é da ordem de $1618 \%$ sendo reduzida para $202 \%$ nesta dose de radiação. Estes resultados estão apresentados na TAB 7. 


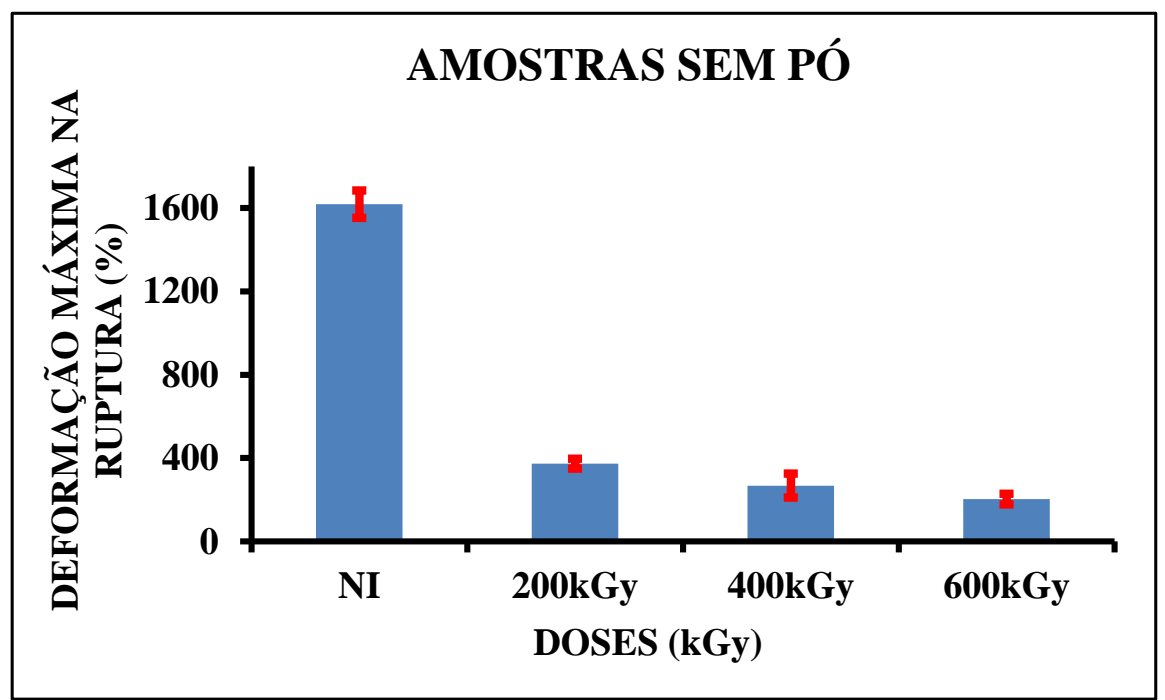

FIGURA 33 - Ensaios mecânicos de deformação máxima na ruptura das amostras de borracha sem pó de pneus inservíveis não irradiadas e irradiadas nas doses de $200 \mathrm{kGy}, 400 \mathrm{kGy}$ e $600 \mathrm{kGy}$

TABELA 7 - Valores médios em (\%) dos ensaios mecânicos de deformação máxima na ruptura das amostras de borracha com pó $(10,30$ e $50 \%)$ e sem pó de pneus inservíveis irradiadas e não irradiadas

\begin{tabular}{ccccc}
\hline \multicolumn{5}{c}{ MÉDIAS (\%) DEFORMAÇÃO MÁXIMA NA RUPTURA } \\
\hline \multirow{2}{*}{ DOSES } & AMOSTRAS & AMOSTRAS & AMOSTRAS & AMOSTRAS \\
& SEM PÓ & 10\% PÓ & $30 \%$ PÓ & 50\% PÓ \\
\hline NI & 1618 & 1411 & 1298 & 999 \\
$200 \mathrm{kGy}$ & 372 & 374 & 456 & 515 \\
400kGy & 267 & 248 & 219 & 279 \\
$600 \mathrm{kGy}$ & 202 & 173 & 183 & 182 \\
\hline
\end{tabular}

Na FIG. 34 são mostrados os resultados da porcentagem de deformação máxima na ruptura para as amostras de borracha com $10 \%$ de pó de pneus inservíveis, irradiadas e não irradiadas. Pode-se observar nesta, FIG. 34, redução da porcentagem de deformação original das amostras de borracha com $10 \%$ de pó de pneus inservíveis à medida que se aumentou a dose de radiação. Observa-se também nesta, FIG. 34, que as amostras irradiadas com a dose de 600kGy apresentaram maior redução da deformação máxima na ruptura, uma vez que a média de deformação original das amostras de borracha com $10 \%$ de pó de pneus inservíveis é da ordem de $1411 \%$ e foi reduzida para $173 \%$ na dose de radiação de 600kGy. Estes resultados estão apresentados na TAB. 7. 


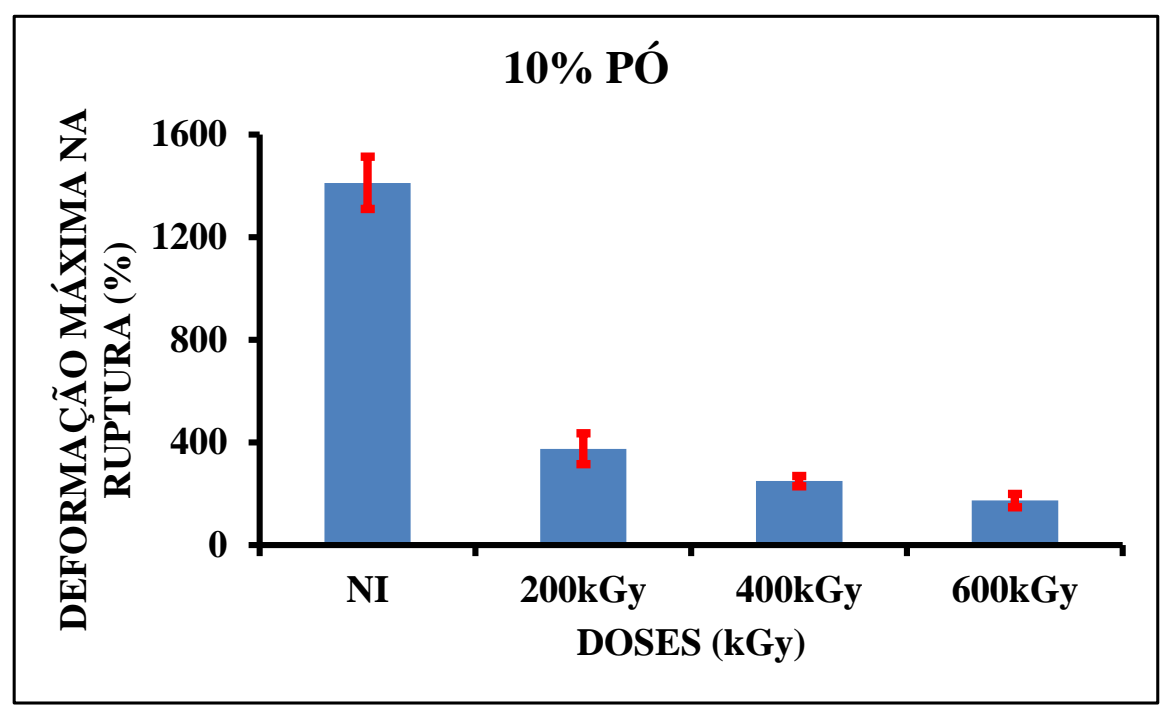

FIGURA 34 - Ensaios mecânicos de deformação máxima na ruptura das amostras de borracha com $10 \%$ de pó de pneus inservíveis não irradiadas e irradiadas nas doses de $200 \mathrm{kGy}, 400 \mathrm{kGy}$ e $600 \mathrm{kGy}$

Na FIG. 35 são mostrados os resultados da porcentagem de deformação máxima na ruptura para as amostras de borracha com $30 \%$ de pó de pneus inservíveis, irradiadas e não irradiadas. Pode-se observar nesta FIG. 35 redução da porcentagem de deformação original da borracha com $30 \%$ de pó de pneus inservíveis à medida que se aumentou a dose de radiação. Observa-se também nesta FIG. 35 que as amostras irradiadas com a dose de $600 \mathrm{kGy}$ apresentaram maior redução, uma vez que a média de deformação original da borracha com $30 \%$ de pó de pneus inservíveis que é da ordem de $1298 \%$ foi reduzida para $183 \%$ na dose de radiação de $600 \mathrm{kGy}$. Estes resultados estão apresentados na TAB. 7. 


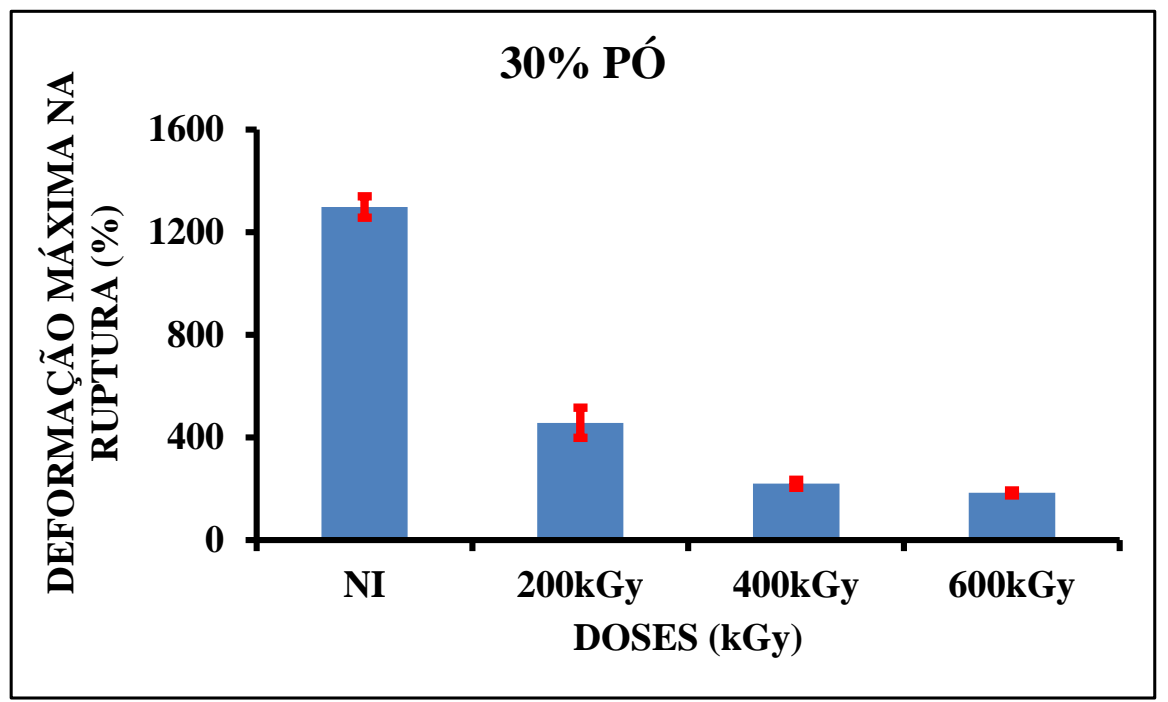

FIGURA 35 - Ensaios de deformação máxima na ruptura das amostras de borracha com $30 \%$ de pó de pneus inservíveis não irradiadas e irradiadas nas doses de $200 \mathrm{kGy}$, $400 \mathrm{kGy}$ e $600 \mathrm{kGy}$

Na FIG. 36 são mostrados os resultados da porcentagem de deformação máxima na ruptura para as amostras de borracha com 50\% de pó de pneus inservíveis, irradiadas e não irradiadas. Pode-se observar nesta FIG. 36, redução da porcentagem de deformação original da borracha com $50 \%$ de pó de pneus inservíveis à medida que se aumentou a dose de radiação. Observa-se também nesta, FIG. 36, que as amostras irradiadas com a dose de 600kGy apresentaram maior redução, uma vez que a média de deformação original da borracha com $50 \%$ de pó de pneus inservíveis que é da ordem de $999 \%$ foi reduzida para $182 \%$ na dose de radiação de $600 \mathrm{kGy}$. Estes resultados estão apresentados na TAB. 7.

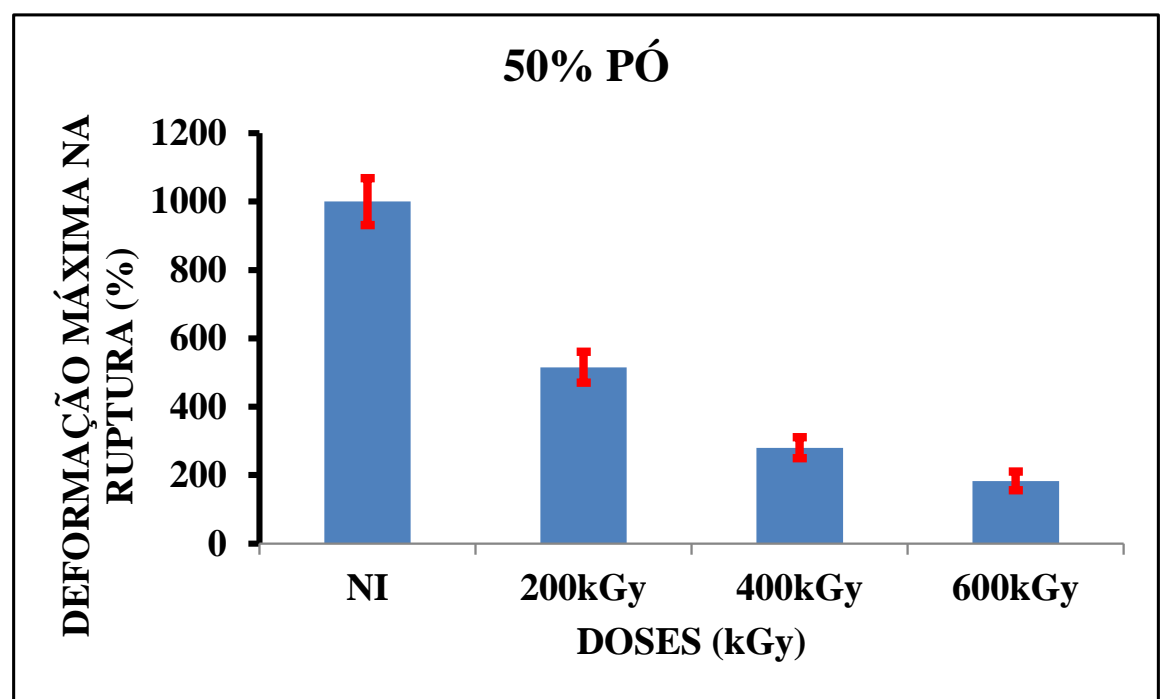

FIGURA 36 - Ensaios mecânicos de deformação máxima na ruptura das amostras de borracha com $50 \%$ de pó de pneus inservíveis não irradiadas e irradiadas nas doses de $200 \mathrm{kGy}, 400 \mathrm{kGy}$ e $600 \mathrm{kGy}$ 
Na FIG. 37 são mostrados os resultados da porcentagem de deformação máxima na ruptura para as amostras de borracha sem pó e com diferentes porcentagens de pó 10, 30 e 50\% de pneus inservíveis para as amostras não irradiadas e irradiadas com 200, 400 e 600kGy. Pode-se observar nesta, FIG. 37, redução na deformação máxima na ruptura conforme o aumento da dose de radiação. Estes resultados estão apresentados na TAB. 8.

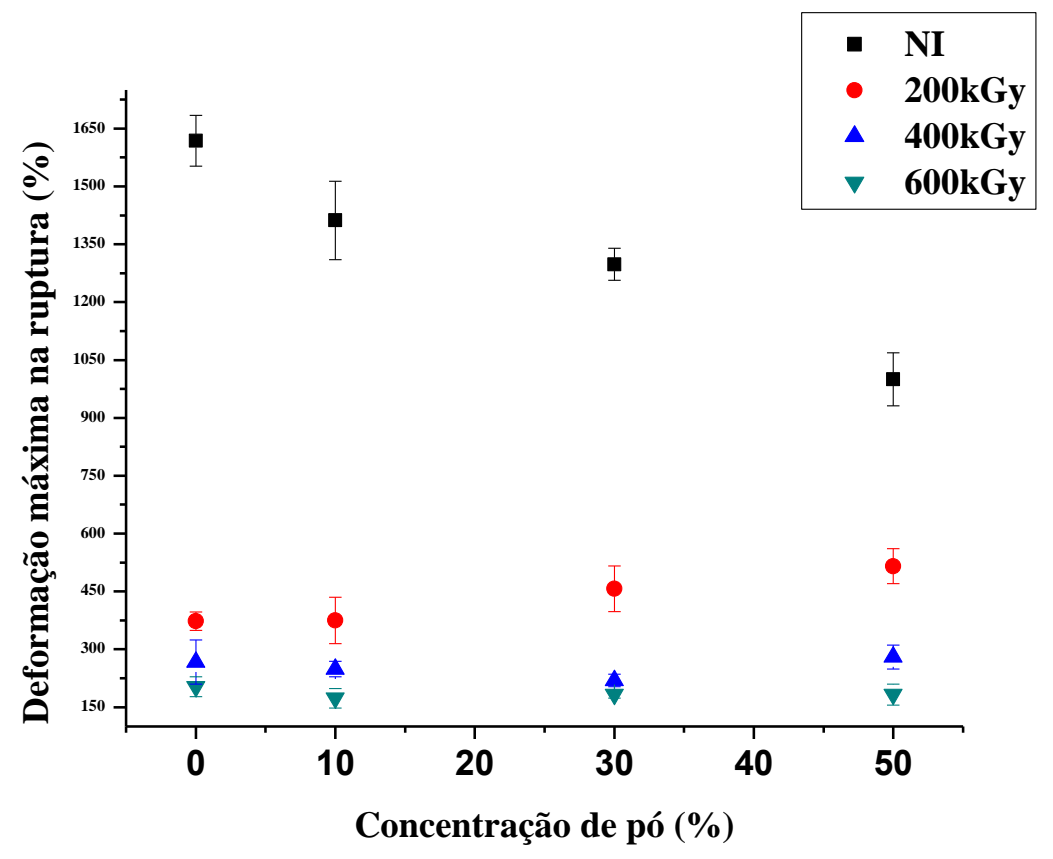

FIGURA 37 - Variação da deformação máxima na ruptura das amostras não irradiadas e irradiadas nas doses de $200 \mathrm{kGy}, 400 \mathrm{kGy}$ e $600 \mathrm{kGy}$ com o aumento da concentração de pó de borracha de pneus inservíveis

Conforme mostrado na FIG. 37, quando se compara as amostras sem pó e as amostras com pó não irradiadas, a amostra sem pó tem um comportamento de ordem de $1618 \%$ na deformação máxima na ruptura enquanto todas as outras amostras com 10, 30 e $50 \%$ de pó tiveram uma perda na deformação máxima na ruptura, 1411\%, 1298\% e 999\% respectivamente. Entretanto para os corpos de prova não irradiados pode ser possível a adição de 10 e 30\% de pó de pneus inservíveis de automóvel para fins de aproveitamento do resíduo. 
TABELA 8 - Deformação máxima na ruptura (\%) para as amostras sem pó e com $10 \%, 30 \%$ e $50 \%$ de pó de pneus inservíveis irradiadas e não irradiadas

\begin{tabular}{c|c|c|c|c}
\hline DOSES/\% & NI & 200kGy & $400 \mathrm{kGy}$ & $600 \mathrm{kGy}$ \\
\hline $\begin{array}{c}\text { AMOSTRAS } \\
\text { SEM PÓ }\end{array}$ & 1618 & 372 & 267 & 202 \\
\hline $\begin{array}{c}\text { AMOSTRAS } \\
\text { 10\% PÓ }\end{array}$ & 1411 & 374 & 248 & 173 \\
\hline $\begin{array}{c}\text { AMOSTRAS } \\
\text { 30\% PÓ }\end{array}$ & 1298 & 456 & 219 & 183 \\
\hline $\begin{array}{c}\text { AMOSTRAS } \\
50 \% \text { PÓ }\end{array}$ & 999 & 515 & 279 & 182 \\
\hline
\end{tabular}

\subsection{FTIR}

Nas FIG. 38, 39 e 40 são mostrados os espectros FTIR ATR para as amostras de grânulos de pneus inservíveis de automóvel não irradiada e irradiadas nas doses de 200, 400 e $600 \mathrm{kGy}$ respectivamente. Analisando estes espectros verifica-se que não houve alteração como mudanças e deslocamentos dos picos devido à irradiação, ou seja, não foi possível detectar modificações causadas pela irradiação para as amostras de grânulos de pneus inservíveis de automóvel.

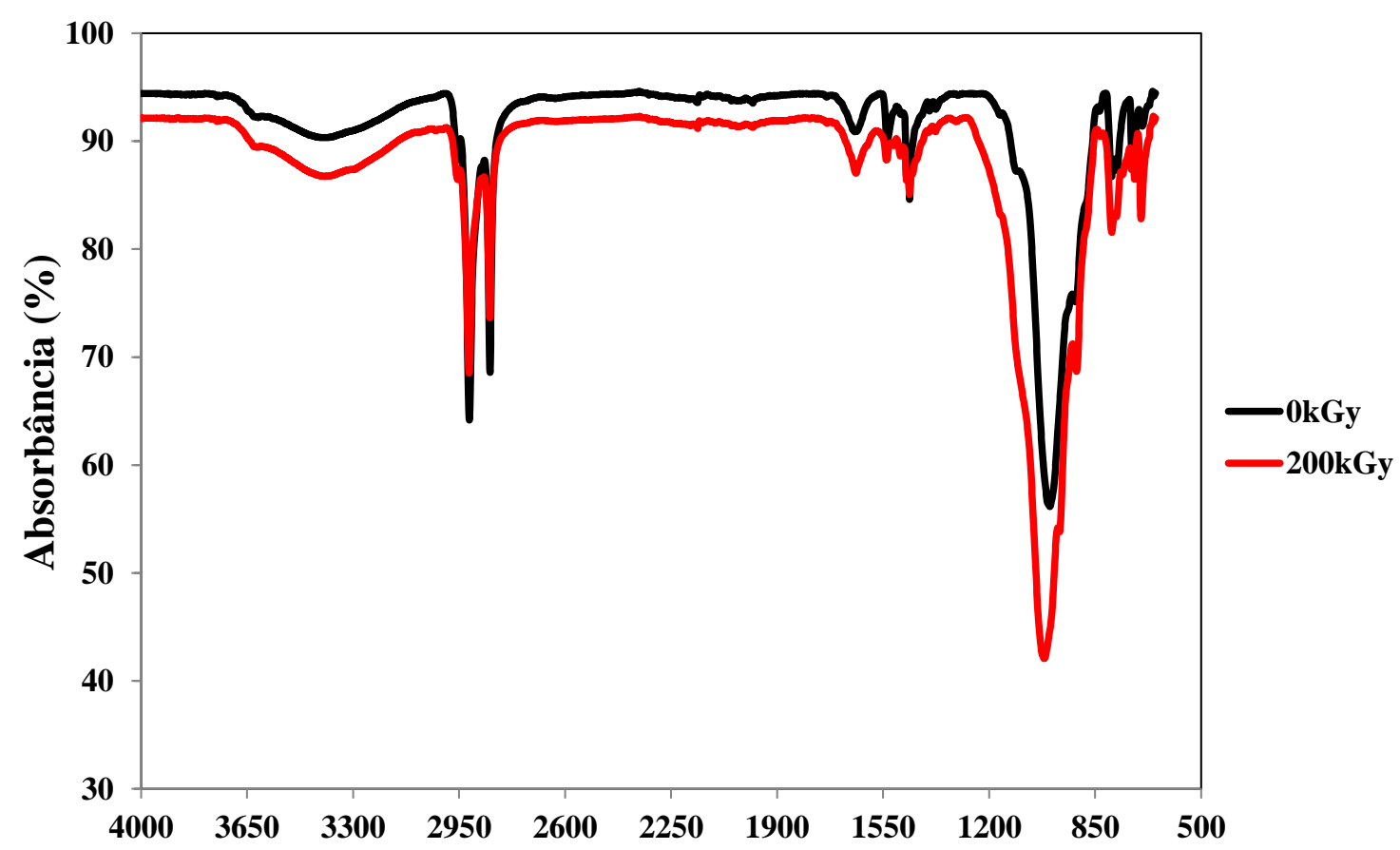

comprimento de onda $\left(\mathrm{cm}^{-1}\right)$

FIGURA 38 - Espectros de absorção na região do infravermelho para as amostras de grânulos de pneus inservíveis de automóvel não irradiada e irradiada na dose de 200kGy 


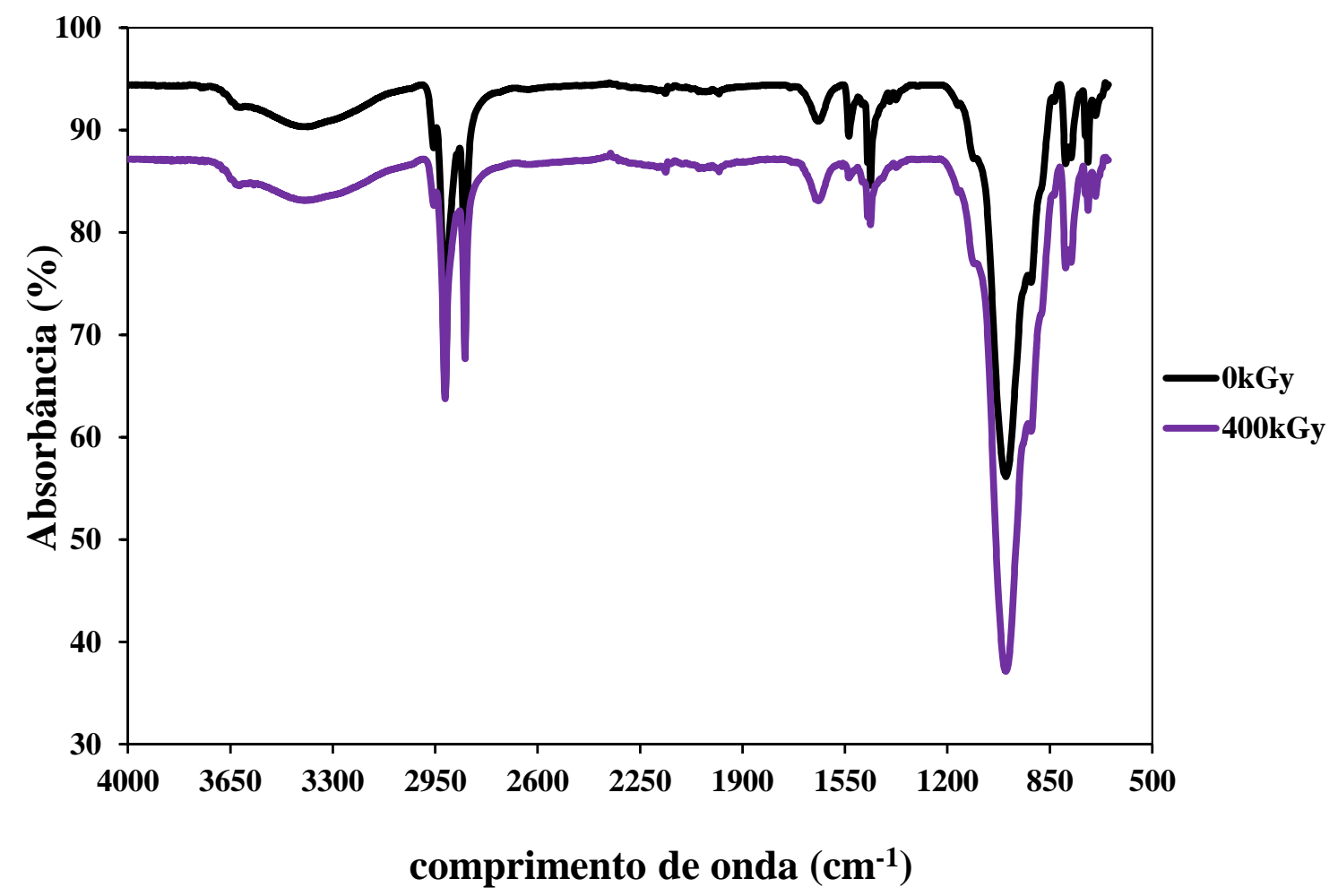

FIGURA 39 - Espectros de absorção na região do infravermelho para as amostras de grânulos de pneus inservíveis de automóvel não irradiada e irradiada na dose de 400kGy

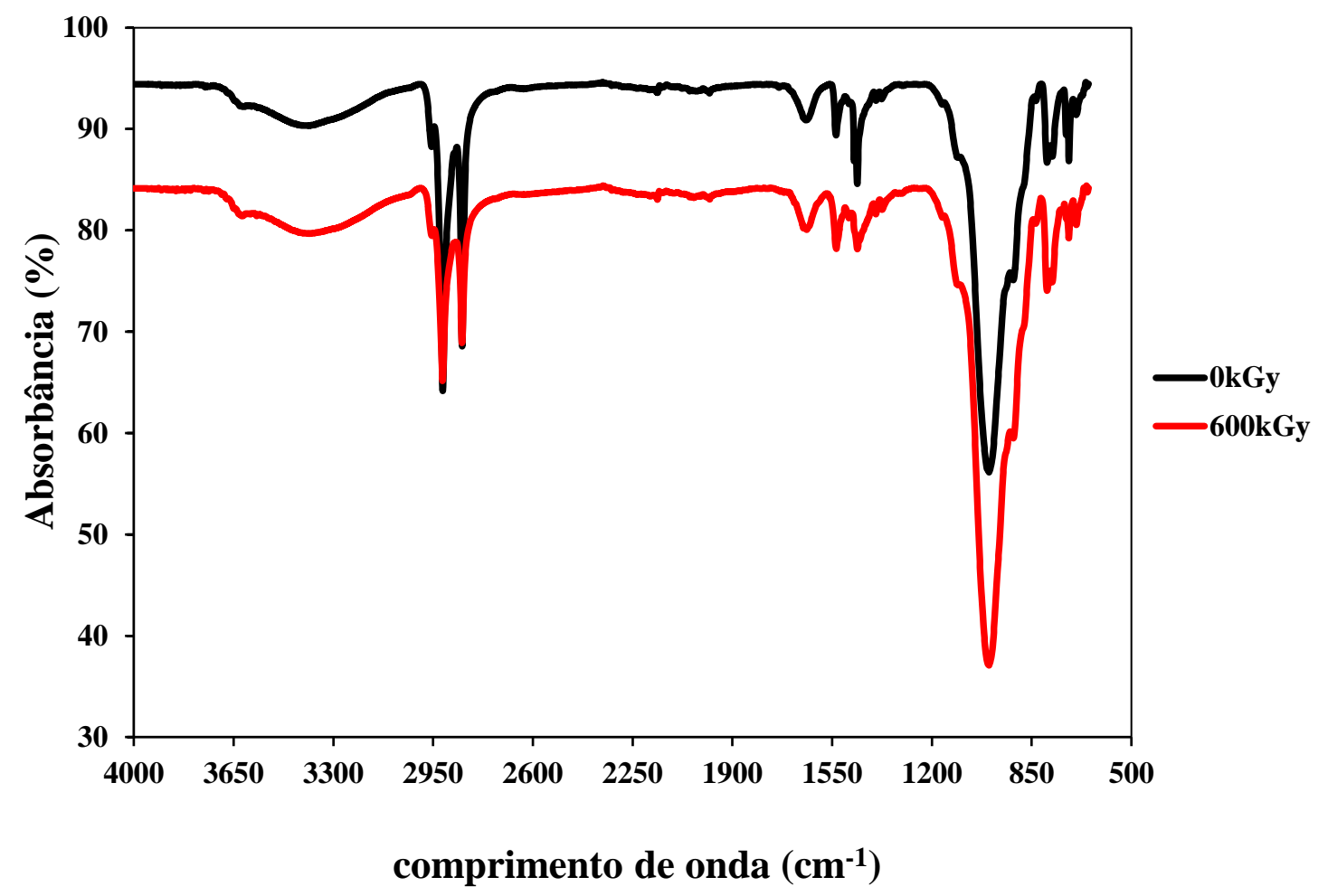

FIGURA 40 - Espectros de absorção na região do infravermelho para as amostras de grânulos de pneus inservíveis de automóvel não irradiada e irradiada na dose de $600 \mathrm{kGy}$ 


\subsection{Microscopia Eletrônica de Varredura}

Nas FIG. 41, 42, 43 e 44 são mostradas as imagens obtidas por microscopia eletrônica de varredura (MEV) das amostras de grânulos de borracha de pneus inservíveis de automóvel não irradiadas e irradiadas com doses de 200, 400 e 600kGy. As micrografias foram ampliadas 32, 100, 500 e 1000 vezes e observada no tamanho de $1 \mathrm{~mm}$, $200 \mu \mathrm{m}, 50 \mu \mathrm{m}, 20 \mu \mathrm{m}$, respectivamente.

Pode-se observar que as amostras irradiadas apresentaram rugosidades e a amostra irradiada com 600kGy também apresentou rupturas com o aumento da dose de radiação.

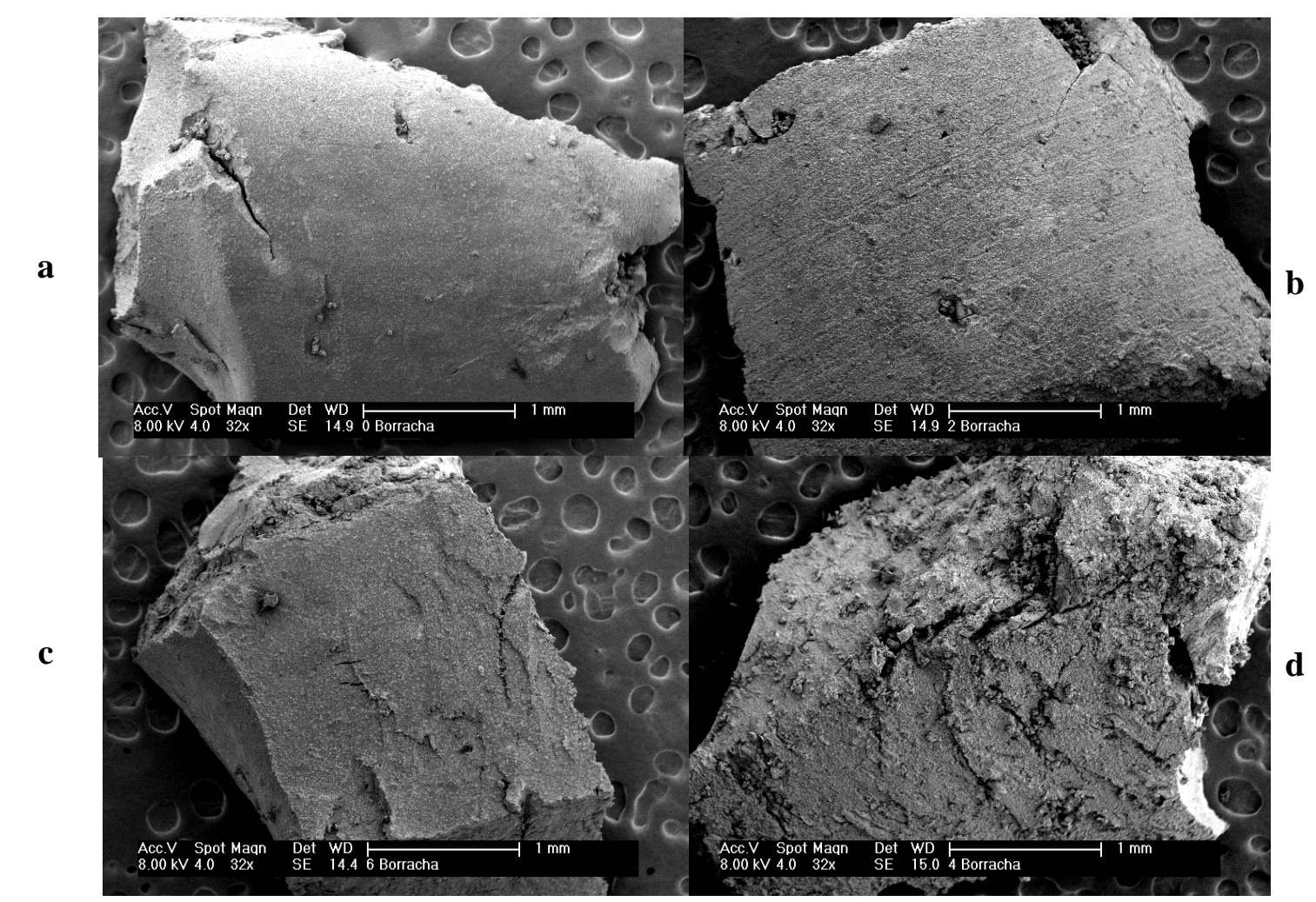

FIGURA 41 - Imagens obtidas por MEV dos grânulos de borracha de pneus inservíveis para aumento de 32 vezes: a) NI, b) $200 \mathrm{kGy}$, c) $400 \mathrm{kGy}$ e d) $600 \mathrm{kGy}$ 


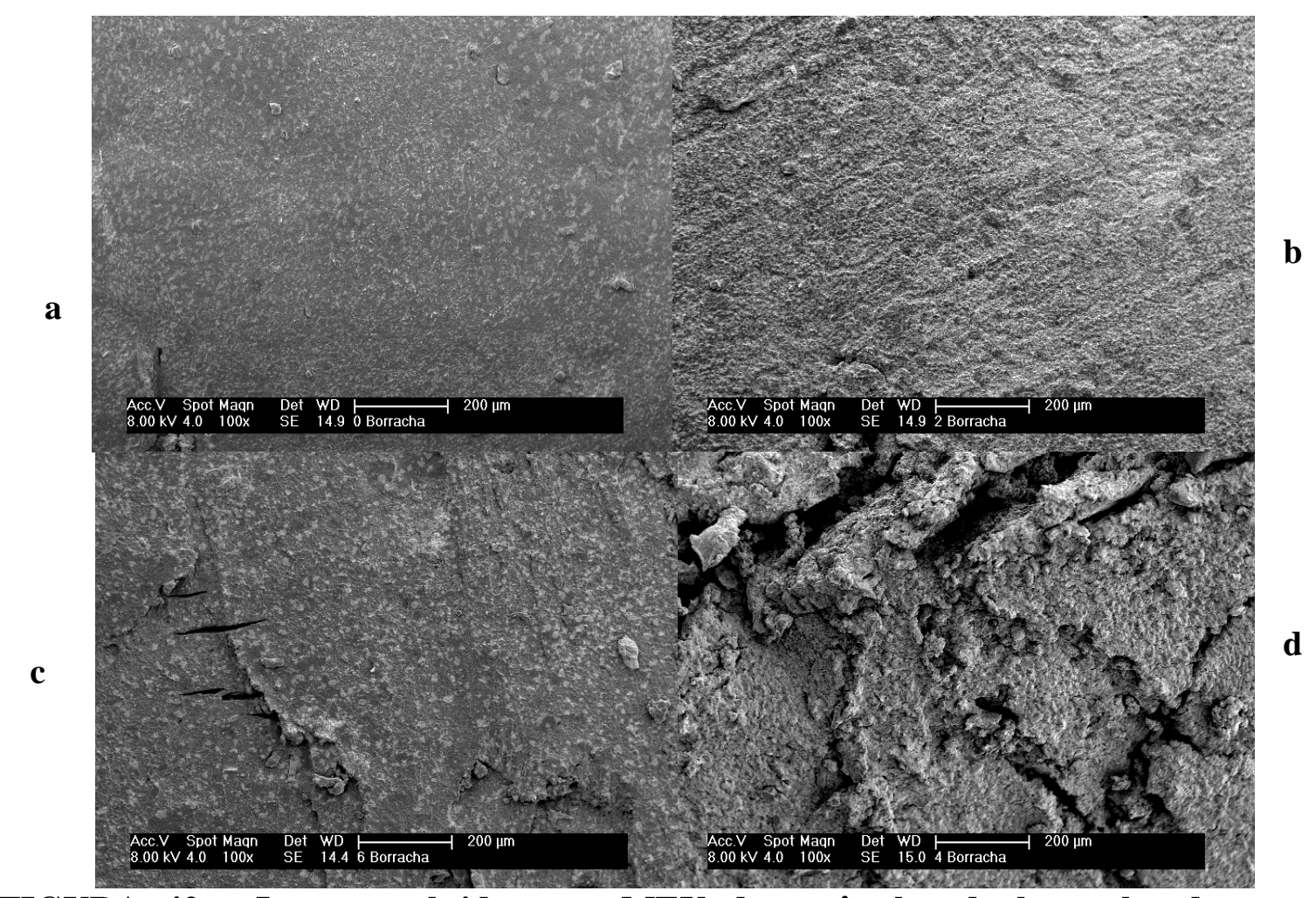

FIGURA 42 - Imagens obtidas por MEV dos grânulos de borracha de pneus inservíveis para aumento de 100 vezes: a) NI, b) $200 \mathrm{kGy}$, c) $400 \mathrm{kGy}$ e d) $600 \mathrm{kGy}$

a

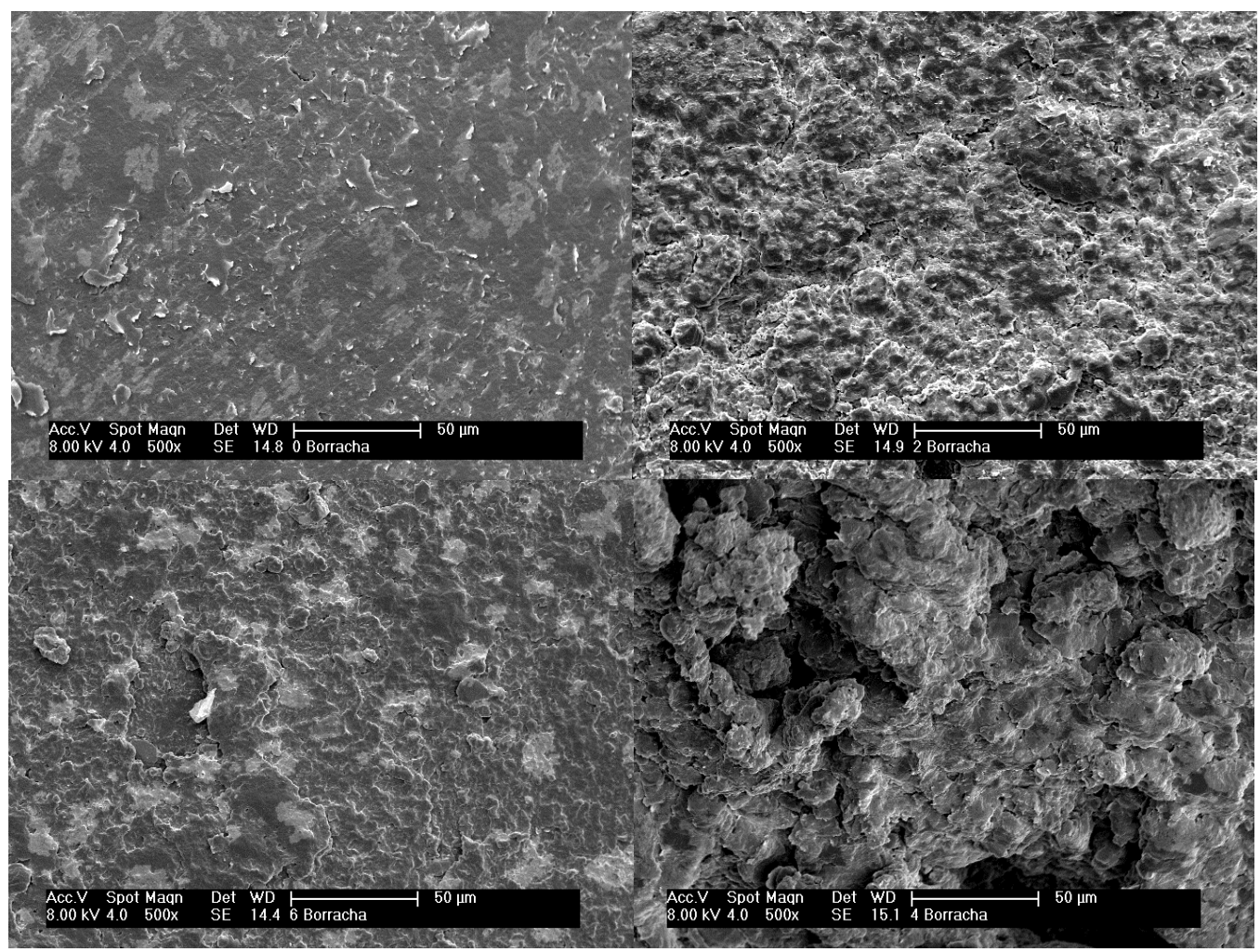

FIGURA 43 - Imagens obtidas por MEV dos grânulos de borracha de pneus inservíveis para aumento de 500 vezes: a) NI, b) $200 \mathrm{kGy}$, c) $400 \mathrm{kGy}$ e d) $600 \mathrm{kGy}$ 
a

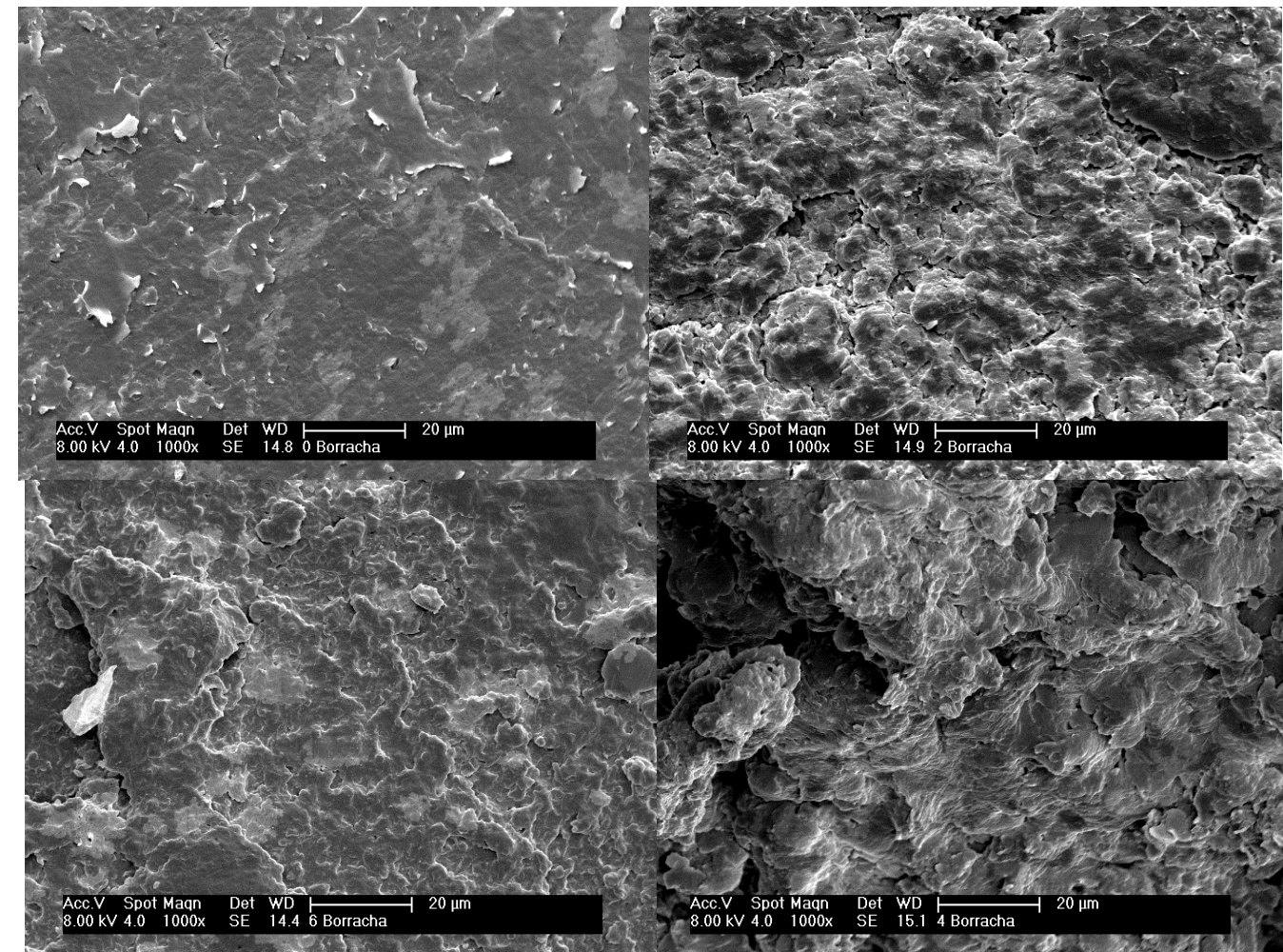

b

d

FIGURA 44 - Imagens obtidas por MEV dos grânulos de borracha de pneus inservíveis para aumento de 1000 vezes: a) NI, b) $200 \mathrm{kGy}$, c) $400 \mathrm{kGy}$ e d) $600 \mathrm{kGy}$

Conforme mostrado nas FIG. 41, 42, 43 e 44 observou-se que a amostra irradiada na dose de $600 \mathrm{kGy}$ apresentou uma maior degradação em comparação com as outras.

Nas FIG. 45 e 46 são mostradas as imagens obtidas por microscopia eletrônica de varredura (MEV) dos corpos de prova sem pó e com adição do pó de borracha de pneus inservíveis de automóvel não irradiados. As micrografias foram ampliadas 500 e 1000 vezes e observadas nos tamanhos de $200 \mu \mathrm{m}$ e $100 \mu \mathrm{m}$, respectivamente.

Pode-se observar que houve boa incorporação do pó de pneus inservíveis de automóvel na matriz elastomérica para as amostras com $10 \%$ e $30 \%$ de pó de pneus inservíveis e que a amostra com 50\% apresentou grânulos superficiais do pó de pneus inservíveis, isso pode ter ocorrido devido à quantidade excessiva de pó, em relação à quantidade de matriz elastomérica. 
$\mathbf{a}$

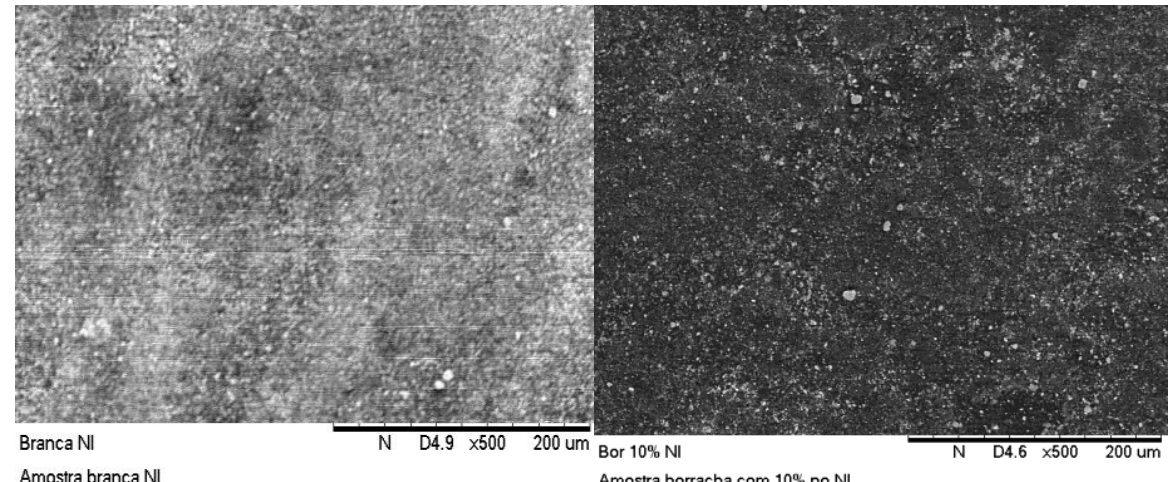

ostra branca N

Amostra borracha com $10 \%$ po N

c

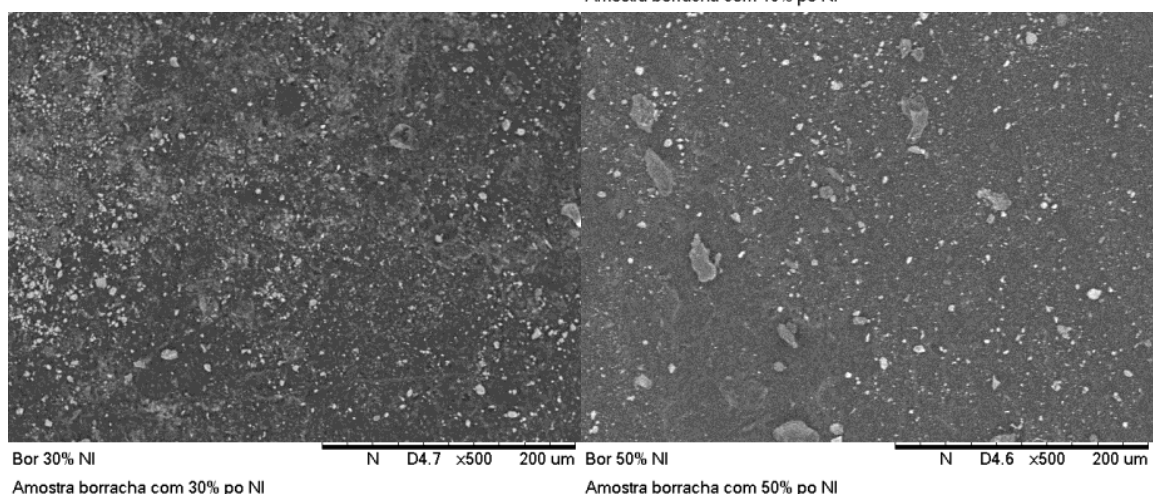

d

FIGURA 45 - Imagens obtidas por MEV dos corpos de prova, sem pó e com pó de borracha de pneus inservíveis não irradiados para aumento de 500 vezes: a) sem pó, b) $10 \%$ pó, c) $30 \%$ pó e d) $50 \%$ pó

$\mathbf{a}$

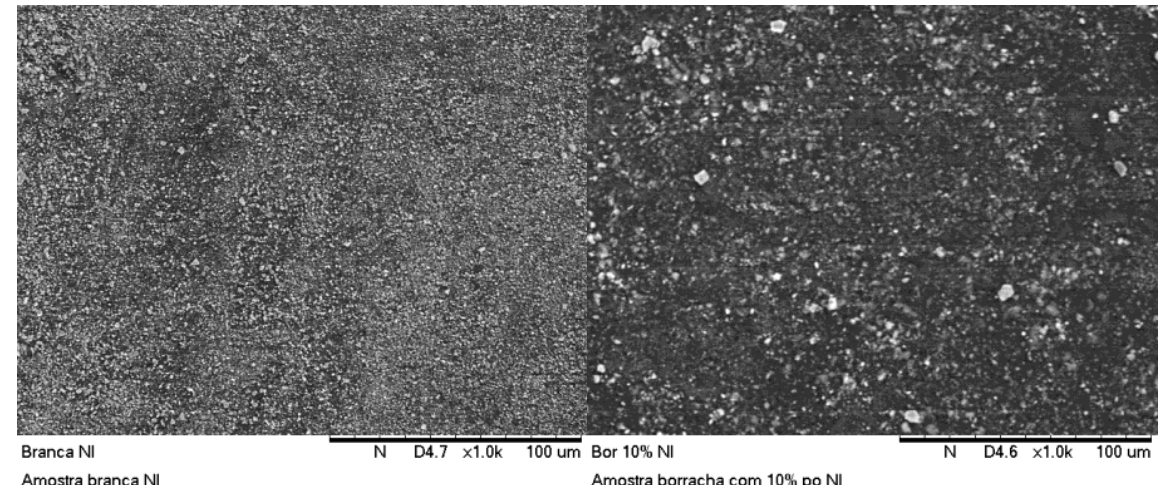

b

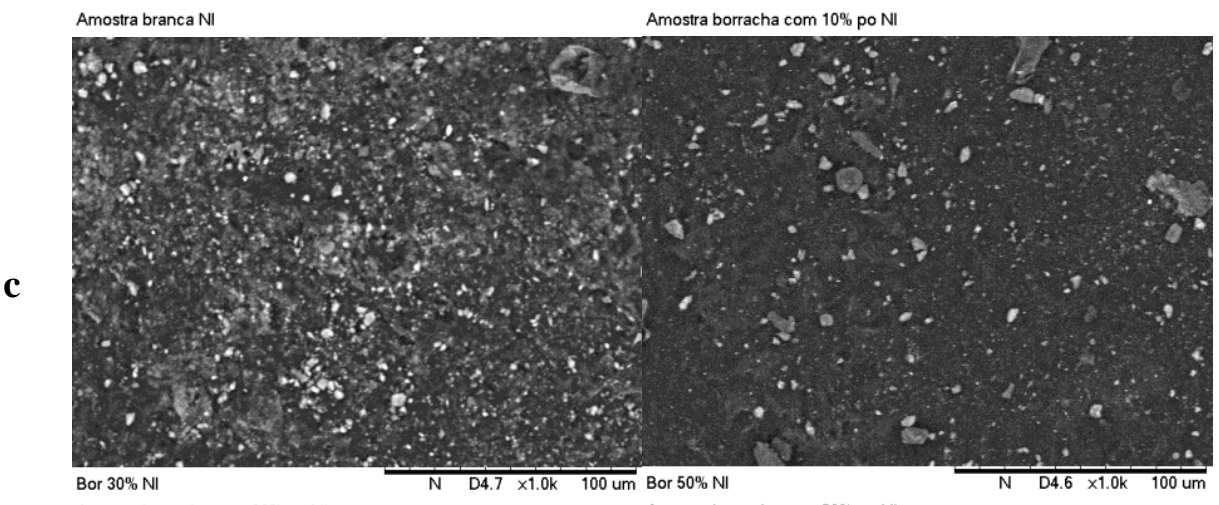

d

FIGURA 46 - Imagens obtidas por MEV dos corpos de prova, sem pó e com pó de borracha de pneus inservíveis não irradiados para aumento de 1000 vezes: a) sem pó, b) $10 \%$ pó, c) $30 \%$ pó e d) $50 \%$ pó 
Nas FIG. 47, 48, 49, 50, 51 e 52 são mostradas as imagens obtidas por microscopia eletrônica de varredura (MEV) dos corpos de prova sem pó e com pó de borracha de pneus inservíveis de automóvel (10, 30 e 50\%) irradiados com doses de 200, 400 e 600kGy. As imagens foram ampliadas 500 e 1000 vezes e observadas nos tamanhos de $200 \mu \mathrm{m}$ e $100 \mu \mathrm{m}$.

Foi observado que à medida que se aumentou a dose de radiação as amostras sem pó e com pó de pneus inservíveis de automóvel degradaram. As amostras com a incorporação de pó adicionado na matriz elastomérica foram se desprendendo da matriz.

a
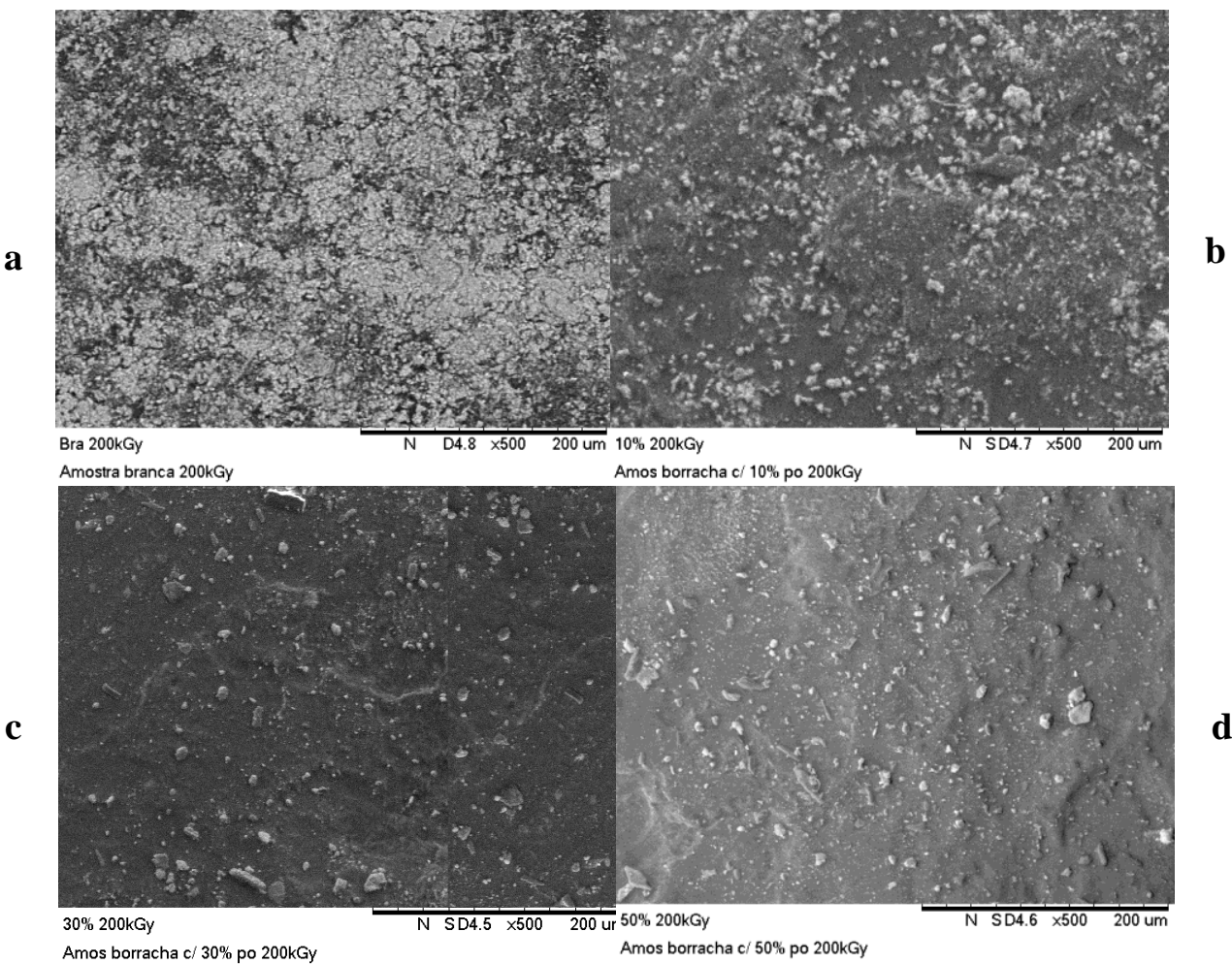

FIGURA 47 - Imagens obtidas por MEV dos corpos de prova, sem pó e com pó de borracha de pneus inservíveis irradiados com dose de $200 \mathrm{kGy}$ para aumento de 500 vezes: a) sem pó, b) $10 \%$ pó, c) $30 \%$ pó e d) $50 \%$ pó 
a

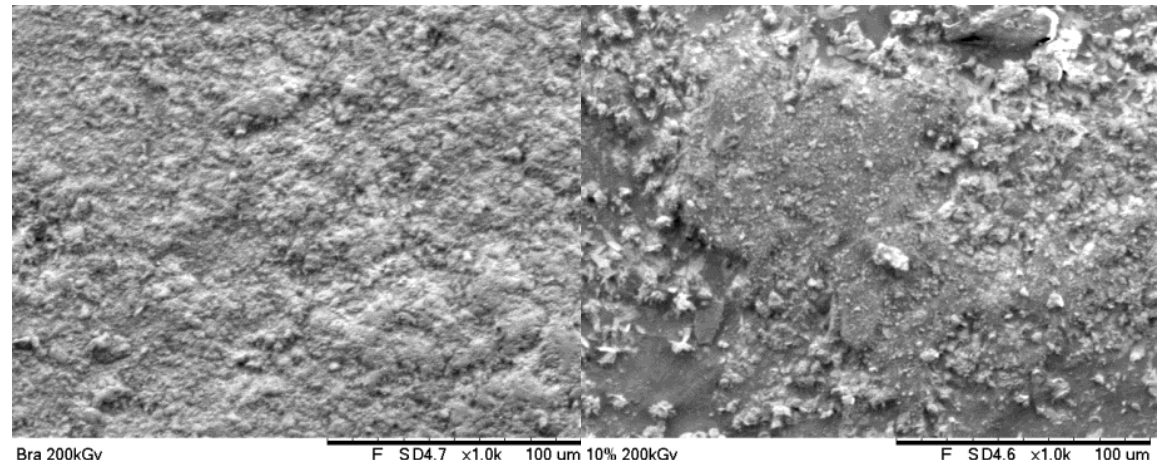

c

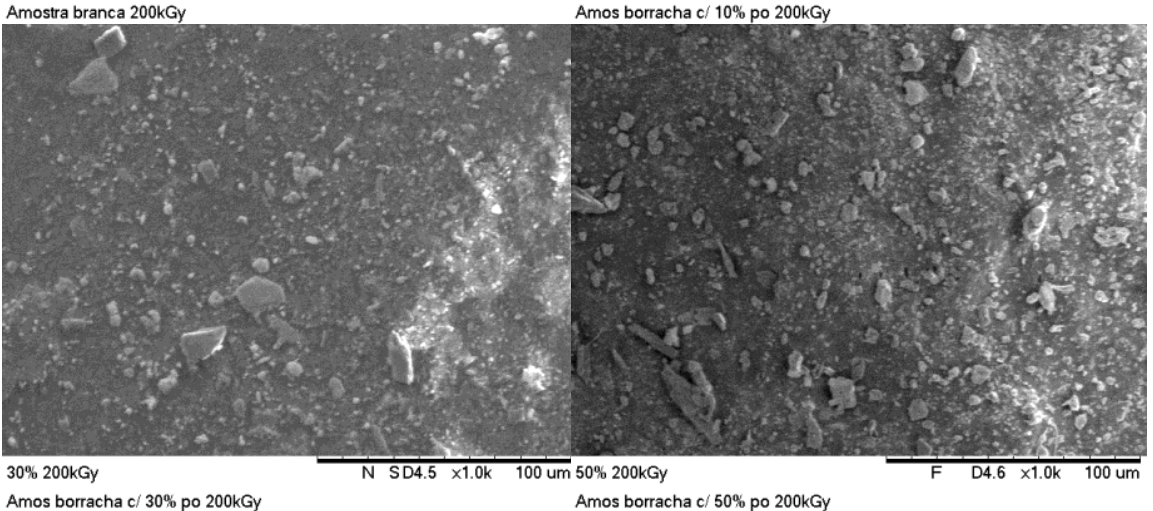

FIGURA 48 - Imagens obtidas por MEV dos corpos de prova, sem pó e com pó de borracha de pneus inservíveis irradiados com dose de $200 \mathrm{kGy}$ para aumento de 1000 vezes: a) sem pó, b) $10 \%$ pó, c) $30 \%$ pó e d) $50 \%$ pó

a

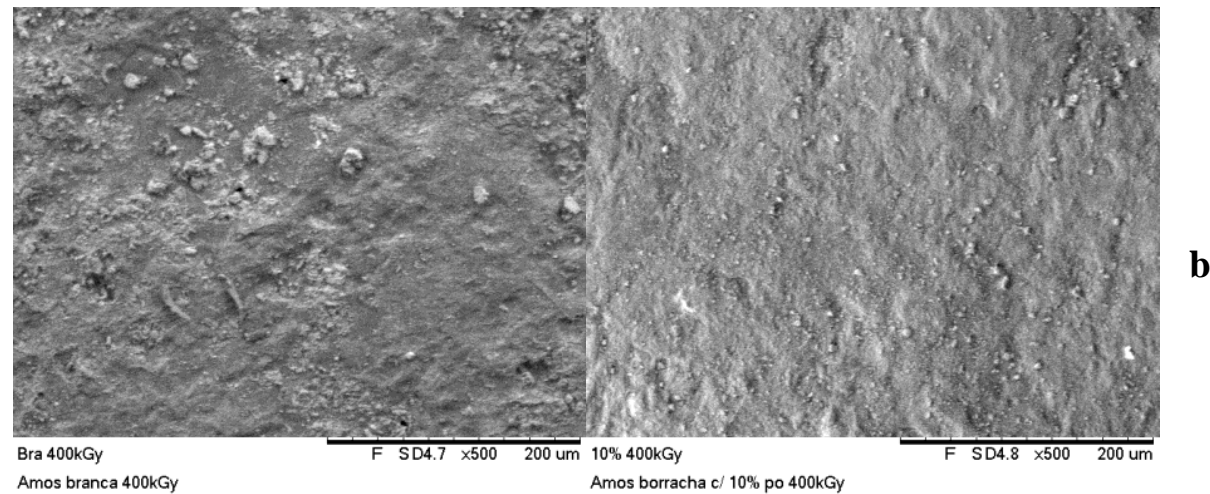

b

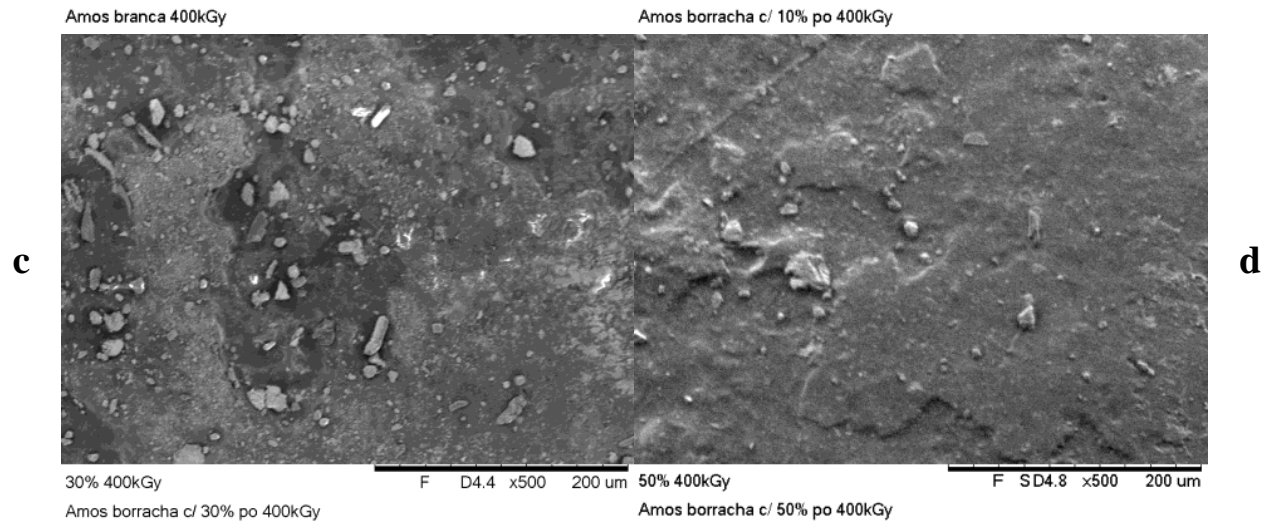

FIGURA 49 - Imagens obtidas por MEV dos corpos de prova, sem pó e com pó de borracha de pneus inservíveis irradiados com dose de $400 \mathrm{kGy}$ para aumento de 500 vezes: a) sem pó, b) $10 \%$ pó, c) $30 \%$ pó e d) $50 \%$ pó 
$\mathbf{a}$

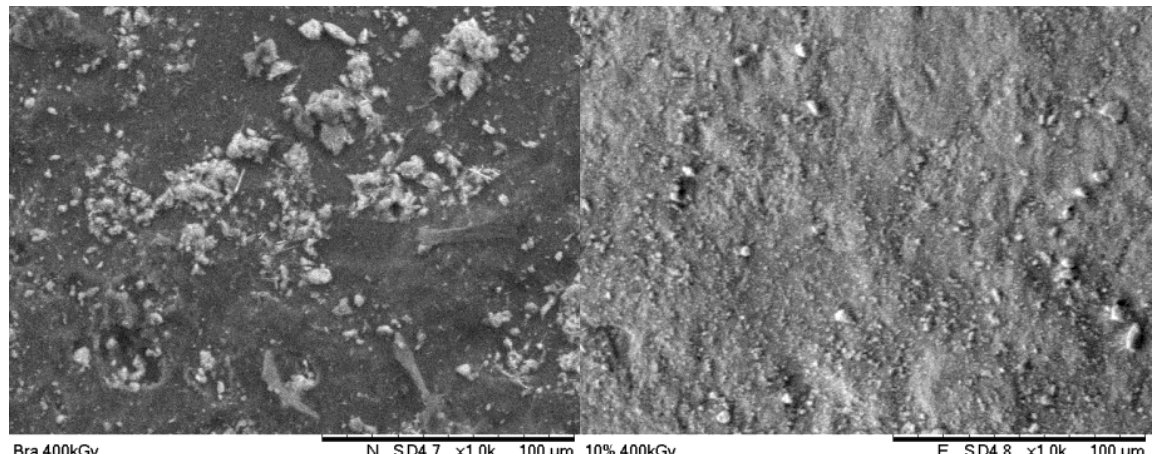

b

c

Amos borracha c/ $10 \%$ po $400 \mathrm{kG}$

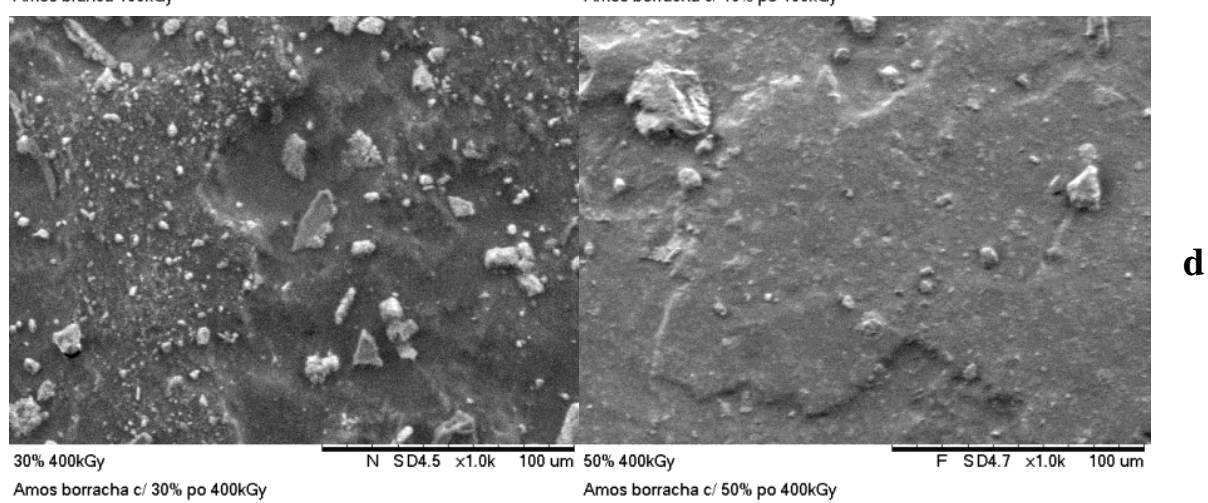

FIGURA 50 - Imagens obtidas por MEV dos corpos de prova, sem pó e com pó de borracha de pneus inservíveis irradiados com dose de $400 \mathrm{kGy}$ para aumento de 1000 vezes: a) sem pó, b) $10 \%$ pó, c) $30 \%$ pó e d) $50 \%$ pó

a
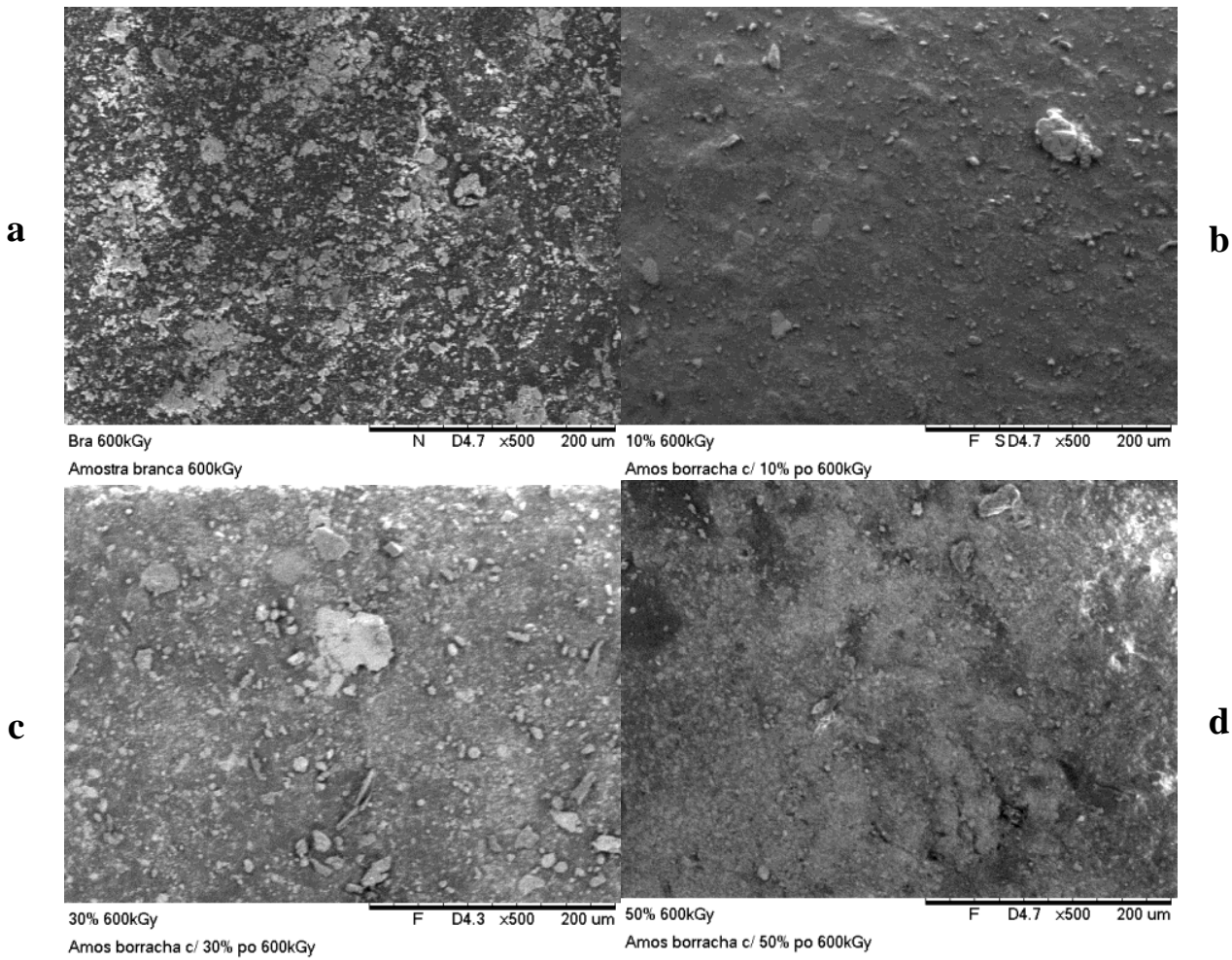

FIGURA 51 - Imagens obtidas por MEV dos corpos de prova, sem pó e com pó de borracha de pneus inservíveis irradiados com dose de $600 \mathrm{kGy}$ para aumento de 500 vezes: a) sem pó, b) $10 \%$ pó, c) $30 \%$ pó e d) $50 \%$ pó 


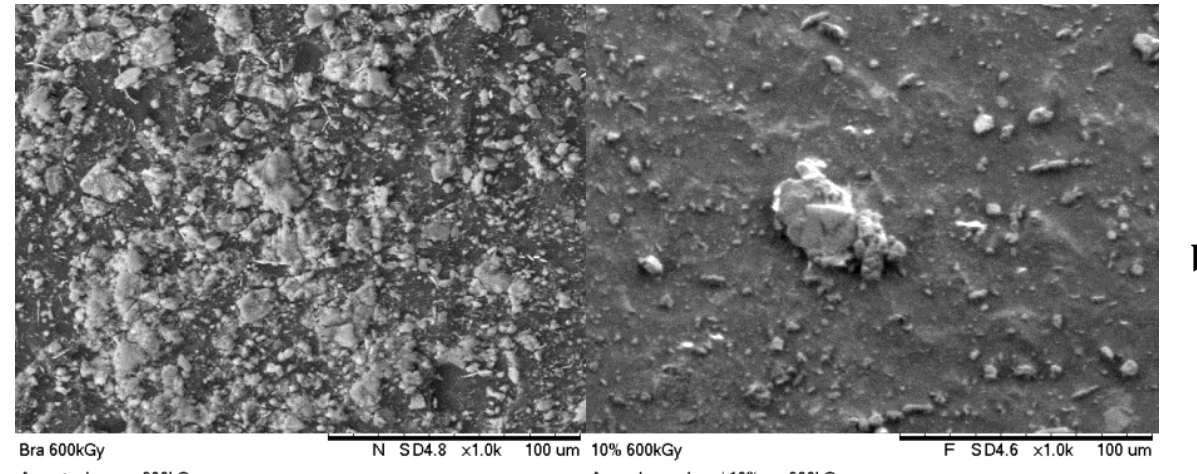

b

c

Amos borracha c/ $10 \%$ po $600 \mathrm{kG}$

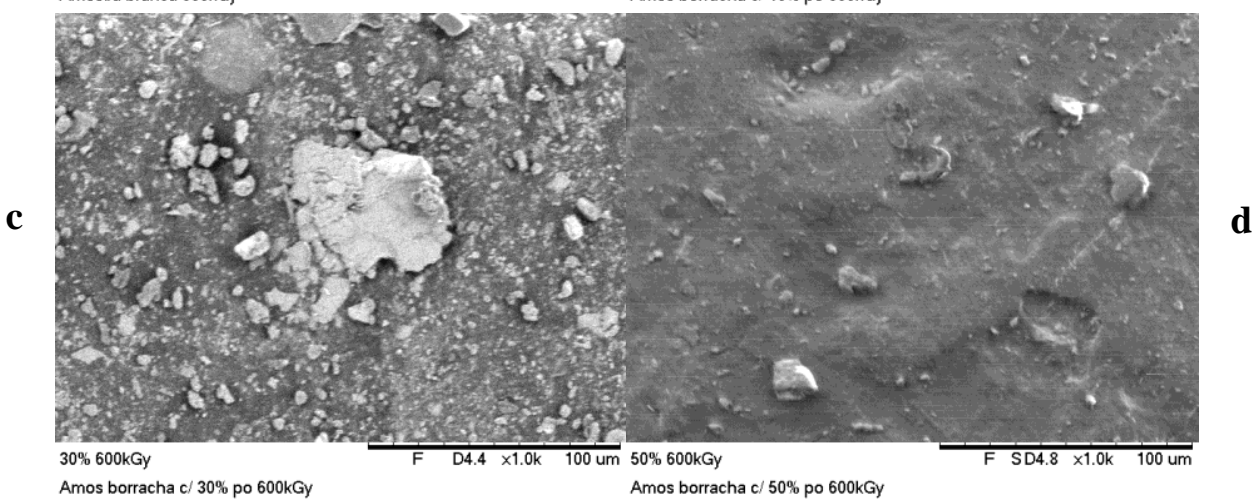

FIGURA 52 - Imagens obtidas por MEV dos corpos de prova, sem pó e com pó de borracha de pneus inservíveis irradiados com dose de $600 \mathrm{kGy}$ para aumento de 1000 vezes: a) sem pó, b) $10 \%$ pó, c) $30 \%$ pó e d) $50 \%$ pó 


\section{CONCLUSÃO}

A partir dos resultados das curvas termogravimétricas obtidas na presença de ar pode-se concluir que nas amostras de grânulos não irradiadas e irradiadas em diferentes doses de radiação, ocorreu uma provável oxidação dos componentes da borracha de pneus inservíveis de automóvel em relação ao aumento da temperatura. O resíduo apresentado provavelmente pode ser óxido de zinco.

Observou-se, pelas curvas termogravimétricas que ocorreu vários eventos. Esses eventos ocorreram em diferentes temperaturas conforme cada dose. Pode-se dizer que houve uma possível degradação quando as amostras foram irradiadas e que o comportamento térmico das amostras sofreram alterações conforme cada dose de radiação.

As amostras de grânulos de borracha de pneus inservíveis de automóvel quando submetidas e caracterizadas pela termogravimetria em nitrogênio $\left(\mathrm{N}_{2}\right)$, mostraram um só evento, não houve oxidação por se tratar de uma atmosfera inerte, possivelmente com o aumento da dose de radiação pode ter ocorrido alterações no comportamento térmico das amostras, mas a estabilidade térmica não sofreu alterações com o aumento da dose de radiação.

Por meio da avaliação térmica destas amostras, é possível observar que o comportamento térmico é variável conforme cada dose de radiação. Nota-se que o comportamento térmico das amostras é uma somatória das curvas de degradação térmica.

Entretanto, o aumento de temperatura promove não só as reações químicas, mas também a volatilização de frações dos componentes. Mesmo assim, a calorimetria exploratória diferencial, DSC, mostrou-se adequada para a determinação do comportamento da degradação, sendo que essa degradação é diferente conforme as doses de radiação.

Nos ensaios mecânicos de deformação máxima na ruptura foi possível observar degradação em relação a todas as amostras irradiadas quando comparadas com as não irradiadas. Portanto para os corpos de prova não irradiados pode ser possível a adição de 10 e 30\% de pó de pneus inservíveis de automóvel para fins de aproveitamento do resíduo.

Em relação aos espectros de FTIR ATR, pode-se dizer que não houve alteração como mudanças e deslocamentos dos picos devido à irradiação, ou seja, a técnica não possui sensibilidade para detectar modificações causadas pela irradiação nas amostras de pneus inservíveis de automóvel. 
Nas micrografias foi possível observar a degradação quando comparadas a amostra não irradiada com as amostras submetidas a diferentes doses de radiação. Na amostra irradiada na dose de 600kGy observou-se uma maior degradação em comparação com as outras.

Foi observado que à medida que se aumentou a dose de radiação, os corpos de prova de borracha natural sem pó e com pó de pneus inservíveis de automóvel degradaram. As amostras irradiadas com a incorporação de pó na matriz elastomérica foram se desprendendo à medida que se aumentou a dose de radiação indicando degradação.

Com a incorporação do pó de pneus inservíveis de automóvel na matriz elastomérica foi possível dar uma destinação ambiental a este resíduo. 


\section{SUGESTÕES PARA TRABALHOS FUTUROS}

Para melhor conhecimento das amostras de borracha de pneus inservíveis de automóvel sugere-se como trabalhos futuros:

$>$ Realizar ensaios de dureza Shore A, nos corpos de prova sem pó e com pó de pneus inservíveis de automóvel, não irradiados e irradiados.

$>$ Realizar ensaios de perfuração, nos corpos de prova sem pó e com pó de pneus inservíveis de automóvel, não irradiados e irradiados.

Realizar ensaios de inchamento/intumescimento, nos corpos de prova sem pó e com pó de pneus inservíveis de automóvel, não irradiados e irradiados.

Avaliar os efeitos da radiação no pó de pneus inservíveis de automóvel e incorporar o pó irradiado na matriz elastomérica.

Avaliar as propriedades nas amostras de pó de pneus inservíveis de automóvel com radiação gama.

$>$ Avaliar as propriedades nos corpos de prova sem pó e com pó de pneus inservíveis de automóvel com radiação gama.

Avaliar as propriedades estudadas, nos corpos de prova sem pó e com pó de pneus inservíveis de automóvel, não irradiados e irradiados ao longo do tempo. 


\section{REFERÊNCIAS BIBLIOGRÁFICAS}

AKISETTY, C.K; LEE, S.J.; AMIRKHANIAN, S.N. Hight temperature properties of rubberized binders containing warn asphalt additives. Construction and Building Materials. 2007.

ALVES, J.O. Síntese de nanotubos de carbono a partir do reaproveitamento de resíduos sólidos carbonosos. 2011. Tese (Doutorado) - Escola Politécnica da Universidade de São Paulo, São Paulo.

AMERICAN SOCIETY FOR TESTING AND MATERIAL STANDARDS. ASTM E2040-08: Standard test method for mass scale calibration of thermogravimetric analysers. West Conshohocken: ASTM International, 3p. 2008.

ANIP. Associação Nacional da Indústria de Pneumáticos. Disponível em: http://www.anip.com.br. Acesso em: 29/07/2011.

ANIP Associação Nacional da Indústria de Pneumáticos Disponível em: http://www.anip.com.br/index.php?cont=detalhes_noticias\&d_=425\&area=43\&titulo_pagi na=Ultimas\%20Noticias Acesso em: 29/07/2012.

BERTOLLO, S.M.; JÚNIOR, J.F.; SCHALCH, V. Benefícios da incorporação de borracha de pneus em pavimentos asfálticos. XVIII Congresso Interamericano de Ingenieria sanitária y Ambiental. 2002.

BIDONE, F.R.A. Conceitos básicos de resíduos sólidos. Escola de Engenharia de São Carlos. São Carlos, 1999.

BILLITER, T. C. The characterization of asphalt - rubber binder. 1996. Thesis (Doctor) - University of Texas.

BOONSTRAN, B.B. Fillers: Carbon black and nonblack. In: MORTON, M. Rubber technology. 2ed. New York, N.Y.: Van Nostrand - Reinhold, p. 51-52, 1973.

BRYDSON, J.A. Rubbery materials and their compounds., New York, N.Y.: Elsevier Applied Science, p. $401-411,1988$.

CALLISTER JÚNIOR, W.D. Materials science and engineering. 3.ed. New York, N.Y.: Wiley, 1994.

CANEVAROLO JÚNIOR, S.V. Ciência dos polímeros: Um texto básico para tecnólogos e engenheiros. São Paulo, S.P.: Artliber, 2002.

CANEVAROLO JÚNIOR, S.V. Técnicas de caracterização de polímeros. São Paulo, S.P.: Artliber, 2003.

CAPONERO, J.; TENÓRIO, J.A.S. Study of the pyrolysis reactions of brazilian waste tires using TGA and DTA. In: 130th TMS Annual Meeting \& Exhibition. New Orleans, EUA, 2001. 
CETESB. Disponível em: http://www.cetesb.sp.gov.br/tecnologia-ambiental/cas-ematividade/53-camara-ambiental-do-setor-de-residuos. Acesso em 12/02/2013.

CHOUBANE, B.; SHOLAR, G. A.; MUSSELMAN, J. A.; PAGE, G. C. Ten-year performance evaluation of asphalt-rubber surface mixes. Transportation Research Record. 1999.

CLEGG, G. Mechanisms of polymer degradation and stabilization, New York, N.Y.: Elsevier, 1991.

CLOUGH R.L.; GILLEN K.T.; MALONE G.M.; WALLACE J.S. Color Formation in Irradiated Polymers. Rad. Phys. Chem., v.48, n.5, p.583-594, 1996.

DOLE, M. Introduction. In: DOLE M. (Ed). The Radiation Chemistry of Macromolecules. New York, N.Y.: Academic, v. I, 1972.

DROBNY, J.G. Radiation technology for polymers. New Hampshire: CRC PRESS, 2002.

DROBNY, J.G. Radiation technology for polymers. New Hampshire: CRC PRESS, 2010.

DAWKINS, J.V. Developments in Polymer Characterization. New York, N.Y.: Elsevier, part 5, 1986.

ELDIN, N.N.; PIEKARSKI, J.A. Scrap Tires: Management and Economics. Journal of Environmental Engineering., v. 119, n.6, p. 1217 - 1232, 1993.

FERRER, G. The economics of tire remanufacturing. Resources, Conservation and Recycling, v.19, n. 4, p. 221-255, Elsevier 1997.

FERRO, W.P. Estudos do efeito da radiação ionizante nas propriedades da poliamida 6.6 com e sem reforço de fibra de vidro. 2003. Dissertação (Mestrado) - Instituto de Pesquisas Energéticas e Nucleares, São Paulo.

GIOLITO, I.; IONASHIRO, M. Nomenclatura, padrões e apresentação dos resultados em análise térmica. Cerâmica, v. 26, n. 121, p. 17-24, 1980.

GOMES, D.M. Estudo dos mecanismos de relaxações dielétrica e mecânica na Borracha Natural, 2008. Dissertação (Mestrado) - Universidade Federal do Paraná, Curitiba.

GOMES, L.P. Estudo da caracterização física e da biodegradabilidade dos resíduos sólidos urbanos em aterros sanitários. 1989. Dissertação (Mestrado) - Escola de Engenharia de São Carlos. Universidade de São Paulo, São Carlos.

GOULAS, A.E.; RIGHANAKOS, K.A.; KONTOMINAS, M.G. Effect of Ionizing Radiation on Physicochemical and Mechanical Properties of Commercial Multilayer Coextruded Flexible Plastics Packaging Materials. Rad. Phys. Chem. v.68, p.865-872, 2003.

HATAKEYAMA, T.; QUINN, F.X. Thermal analysis fundamentals and application to polymer science. 2.ed. Chichester. Willey, p. 68,1999. 
HEDVIG, P. Theory of Free Radicals. In DOLE, M. (Ed). The Radiation chemistry of Macromolecules. New York, N.Y.: Academic, v. I, 1972.

HERTZ Jr., D.L. Theory \& Practice of Vulcanization. Elastomerics. London, 1984.

HIRAYAMA, D.; SARON, C.; BARBOZA, J.C.S. Avaliação por FTIR das mudanças químicas ocorridas na borracha SBR após desvulcanização por microondas. In: CBECIMAT, n. 18, Porto de Galinhas. Anais... Porto de Galinhas, 2008.

INTERNATIONAL ATOMIC ENERGY AGENCY (IAEA). Radiation Safety of Gamma an Electron Irradiation Facilities, Viena - Austria. 1992.

JENSEN, W.B. Lewis acid-Base Interactions and adhesion Theory. Rubber Chemistry and Technology, v. 55, p. 881-901, New York, 1982.

KARAAGAÇ, B.; SEN, M.; DENIZ, V.; GÜVEN, O. Recycling of gamma irradiated inner tubes in butyl based rubber compounds. Nuclear Instruments and Methods. in Physics Research Section B, v. 265, p. 290-293, 2007.

KODAMA, Y. Avaliação dos efeitos da radiação ionizante em compósitos de PCL/PLLA com fibra de coco. 2010. Tese (Doutorado) - Instituto de Pesquisas Energéticas e Nucleares, São Paulo.

LANDI, T.R.L. Estudo do efeito da radiação ionizante por feixe de elétrons sobre o terpolímero acrilonitrila butadieno estireno ABS. 2003. Dissertação (Mestrado) Instituto de Pesquisas Energéticas e Nucleares, São Paulo.

LI, S.; LAMMINMÄKI, J.; HANHI, K. Effect of Ground Rubber Power and Devulcanizates on Properties of Natural Rubber Compounds, Journal of Applied Polymer Science, v. 97, n. 1, p. 208-217, 2005.

LIMA, C.S. Caracterização de ligantes asfálticos modificados com borracha de pneu e aditivo. 2008. Dissertação (Mestrado) - Universidade Federal do Ceará, Fortaleza.

LOADMAN, M.J.R. The Exploitation of Natural Rubber. Malaysian Rubber Producers Research Association. Publication 1531, 2000.

LUCAS, E.F.; SOARES, B.G.; MONTEIRO, E.E.C. Caracterização de polímeros: determinação de peso molecular e análise térmica. Rio de Janeiro, R.J.: E-papers, p. 219221, 151-153, 160, 2001.

MANO, E.B. Meio Ambiente, Poluição e Reciclagem. 1. ed. São Paulo, S.P.: Edgard Blücher, 2005.

MARTIN, D.; CALINESCU, I.; IGHIGEANU, D.; IOVU, H.; MATEESCU, E.; CRACIUN, G. Microwave apparatus for applied, chemistry. Disponível em: http:// www.cael.pub.ro/cicic/tco/07-25.pdf. Acesso em: 10 out. 2010.

MARTINS, H.A.F. A utilização da borracha de pneus na pavimentação asfáltica. 2004. Dissertação (Mestrado) - Universidade Anhembi Morumbi, São Paulo. 
MATOS, J.R. Apostila da disciplina MPT6017 Análise Térmica Aplicada à Tecnologia, São Paulo, 2012.

MEHNERT, R. Electron Beam in Research and Technology. Nuclear Instruments and Methods in Physics Research - Section B, v.105, p. 348-358, 1995.

MENNIG, G. Concepts for Reclaim of Rubber Waste in Europe. Plastics. Rubber and Composites Processing and Aplications, v. 27, n. 7, p. 346-348, 1998.

MIRANDA, L.F. Estudo de parâmetros de processo para a síntese de membranas hidrofilicas a base de poli(n-vinil-2-pirrolidona. 1999. Tese (Doutorado) - Instituto de Pesquisas Energéticas e Nucleares, São Paulo.

MISAWA, C.K.O. Análise qualitativa e quantitativa de compostos de borracha destinados à fabricação de revestimentos de embreagem. 2011. Tese (Doutorado) Instituto de Química da Universidade de São Paulo, São Paulo.

MORTON, M.; FETTERS, L.J. Rubber Chem. Technology. New York, N.Y. 1975.

MOURA, E.A.B. Avaliação do desempenho de embalagens para alimentos quando submetidas a tratamento por irradiação ionizante. 2006. Tese (Doutorado) - Instituto de Pesquisas Energéticas e Nucleares, São Paulo.

NAUTON, W.J.S. The Applied Science of rubber. Edward Arnold Publishers, London, 1961.

NAVARRO, F.J.; PARTAL, P.; MARTINEZ-BOZA, F.; GALLEGOS, C. Thermorheological behaviour and storage stability of ground tire rubber- modified bitumens. Fuel, v. 83, p. $2041-2049.2004$.

NAVARRO, F. J.; PARTAL, P.; MARTINEZ-BOZA, F.; VALENCIA, C.; GALLEGOS, C. Rheological characteristics of ground tire rubber - modified bitumens. Chem. Eng. J., v. 89, p. 53-61. 2002.

O'DONNELL, J.H.; SANGSTER, D.F. Principles of radiation chemistry. London, Edward Arnold, 1970.

ORTIZ, A.V. Avaliação de propriedades mecânicas e de barreira a gases em embalagem plástica multicamada composta de polietileno de baixa densidade e poliamida tratada com radiação ionizante. 2005. Dissertação (Mestrado) - Escola Politécnica da Universidade de São Paulo, São Paulo.

PADILHA, A.F. Materiais de Engenharia. Microestruturas e Propriedades, ed. Hemus, Curitiba, 2000.

PINHEIRO, E.G. Modelos numéricos aplicados à vulcanização de pneus. 2001. Dissertação (Mestrado) - Escola Politécnica da Universidade de São Paulo, São Paulo.

PORTAL SÃO FRANCISCO. Disponível em: http://www.portalsaofrancisco.com.br /alfa/historia-da-borracha/historia-do-pneu.php. Acesso em: 29/07/2011. 
RECICLANIP. Disponível em: http://www.reciclanip.com.br/v3/legislacao\#. Acesso em $10 / 04 / 2013$.

RODRIGUES, M.R.P. Caracterização do resíduo da borracha de pneus inservíveis em compostos aplicáveis na construção civil. 2008. Tese (Doutorado) - Escola de Engenharia de São Carlos da Universidade de São Paulo, São Carlos.

SALTMAN, W.M. Styrene-buatdiene rubbers. In: MORTON, M. Rubber technology. 2. Ed. New York: Van Nostrand-Renhold, p. 178-1851973.

SEGRE, N.C. Reutilização de borracha de pneus usados como adição em pasta de cimento. 1999. Tese (Doutorado) - Universidade Estadual de Campinas. Instituto de Química da Universidade de Campinas, São Paulo.

SCURACCHIO, C.H.; WAIKI, D.A.; BRETAS, R.E.S. Caracterização térmica e reológica de borracha de pneu desvulcanizada por microondas. Polímeros: Ciência e Tecnologia, v. 16, n. 1, p. 46-52, 2006.

SCURACCHIO, C.H.; WAIKI, D.A. Análise dinâmico mecânica de borracha de pneu desvulcanizada por microondas. In: $8^{\circ}$ Congresso Brasileiro de Polímeros, Águas de Lindóia. Anais... Águas de Lindóia: ABPol, 2005, CD-ROM.

SILVERSTEIN R.M, BASSLER G.C., MORRILL T.C. Spectrometric Identification of Organic Compounds, New York, N.Y.: Wiley, 1979.

SOUZA, C.M. Avaliação dos efeitos da radiação por feixe de elétrons nas propriedades mecânicas do polipropileno. 2009. Monografia (Graduação) - Faculdade de Tecnologia da Zona Leste, São Paulo.

SWALLOW, A.J. Radiation chemistry of organic compounds. Cambridge: Pergamon Press, 1960.

TABATA, Y. Fundamentais in radiation chemistry, Jetro - Japan (External Trade Organization), p. 1-17, 1981. In: MOURA, E. A. B. Avaliação do desempenho de embalagens para alimentos quando submetidas a tratamento por irradiação ionizante. 2006. Tese (Doutorado) - Instituto de Pesquisas Energéticas e Nucleares, São Paulo.

TANAKA, Y. Structural Characterizationof Natural Polyisoprenes: solve the mistery of Natural Rubber based on Structural Study. Rubber Chemistry and Technology, v. 74, n. 3; p. 335-375, 2001.

TANG, Y. Recycled Rubber Processing and Performance Enhancement. US Patent 6,590,042, ag. 2003.

TELNOV, A.V.; ZAVYALOV, N.V.; KHOKHLOV, Y.A.; SITNIKOV, N.P.; SMETANIN, M.L.; TARANTASOV, V.P.; SHADRIN, D.N.; SHORIKOV, I,V.; LIAKUMOVICH; A.L.; MIRYASOVA, F.K. Radiation Degradation of Spent Butyl Rubbers, Rad. Phys. Chem., v. 63, p. 245-248, 2002.

VÉRTES, A.; NAGY, S.; KLENCSÁR Z. (eds.) Handbook of nuclear chemistry: chemical applications of nuclear reactions and radiations. Dordrecht: Kluwer Academic Pub., v. 3, p. 36-44, 2003. 
VIEIRA, A.M.F. Processamento e caracterização de misturas de PEBD virgem e reciclado com borracha de pneus desvulcanizados por microondas. 2009. Dissertação (Mestrado) - Universidade Estadual de Ponta Grossa, Ponta Grossa.

WENDLANT, W.W. Thermal analysis. 3. ed. New York, N.Y.: Willey, p.1, 52-53, 1985.

WIEBECK, H.; ESPER, F.; FEIJÓ, A.C. Tecnologia da Borracha. Cooperação Universidade Empresa CECAE/USP, 2002.

WIEBECK, H.; PIVA, A.M. Reciclagem do plástico. São Paulo, S.P.: Artliber, 2004.

WIEBECK, H.; RISSO, W.; HARADA, J. Reciclagem do Plástico e suas Aplicações Industriais. Cooperação Universidade Empresa, Projeto Atual, Treinamento Tecnológico. Apostila da FUSP. São Paulo, 2002.

YAMASAKI, M.C.R. A cura de tintas, vernizes e revestimentos por ultravioleta e feixe de elétrons - conceitos básicos. Apostila elaborada para o curso. Associação Técnica Brasileira de Cura por Radiação - ATBCR e IPEN-CNEN/SP, São Paulo, 1997. 